UNIVERSIDADE DE SÃO PAULO

FACULDADE DE FILOSOFIA, LETRAS E CIÊNCIAS HUMANAS DEPARTAMENTO DE LETRAS CLÁSSICAS E VERNÁCULAS

PROGRAMA DE FILOLOGIA E LÍNGUA PORTUGUESA

GENIZE MOLINA ZILIO BARROS

GÊNERO ARGUMENTATIVO NO ENSINO FUNDAMENTAL I Análise de produções de alunos participantes do Prêmio Escrevendo o Futuro - 2004. 
GENIZE MOLINA ZILIO BARROS

\title{
GÊNERO ARGUMENTATIVO NO ENSINO FUNDAMENTAL I - Análise de produções de alunos participantes do Prêmio Escrevendo o Futuro - 2004.
}

\begin{abstract}
Dissertação apresentada ao Programa de Pós-Graduação em Língua Portuguesa, do Departamento de Letras Clássicas e Vernáculas da Faculdade de Filosofia, Letras e Ciências Humanas da Universidade de São Paulo, para obtenção do título de Mestre em Letras.
\end{abstract}

Orientadora: Profa ${ }^{a}$. Drª. Norma Seltzer Goldstein 
FOLHA DE APROVAÇÃO

Genize Molina Zilio Barros

Gênero Argumentativo no Ensino Fundamental I:

Análise de produções de alunos participantes

do Prêmio Escrevendo o Futuro - 2004.

Dissertação apresentada à Faculdade de Filosofia, Letras Clássicas e Vernáculas da Universidade de São Paulo para a obtenção do título de Mestre.

Área de Concentração: Filologia e Língua Portuguesa

Aprovado em:

Banca Examinadora

Prof $\stackrel{\text { a }}{ }$ Dr $^{\mathrm{a}}$.

Instituição:

Assinatura:

Prof ${ }^{a}$. Dra .

Instituição:

Assinatura:

Profa ${ }^{\text {a }}$ Dra ${ }^{\mathrm{a}}$.

Instituição: Assinatura:

Prof ${ }^{a}$. Dr ${ }^{\mathrm{a}}$.

Instituição:

Assinatura:

Profạ. Dra .

Instituição:

Assinatura: 


\section{DEDICATÓRIA}

Para José Francisco, Bruna e Caterine que tanto me apoiaram nesta jornada de crescimento, por entenderem minhas buscas, por me incentivarem, por acreditarem em mim.

Para meus pais, Afonso Zilio e Lourdes Molina Peres Zilio, pelo legado ético e moral, pelo desvelo em minha criação. 


\section{AGRADECIMENTOS}

À Profa ${ }^{a}$. Dr ${ }^{a}$. Norma Seltzer Goldstein pelo cuidado, atenção, disponibilidade, contribuições e, principalmente, pelo respeito ao meu aprendizado, lições que marcaram minha vida acadêmica.

À Prof ${ }^{a}$. Dr . Lineide do Lago Salvador Mosca e à Prof ${ }^{a}$. Dr . Maria Silvia Louzada, argüidoras da banca de qualificação, pela leitura atenta e cuidadosa, pelas sugestões que permitiram definir melhor os rumos de minha pesquisa e pela enobrecedora oportunidade da convivência.

Ao CENPEC (Centro de Estudos e Pesquisas em Educação, Cultura e Ação Comunitária), particularmente à sua direção - Maria Alice Setúbal - e à equipe organizadora do Prêmio Escrevendo o Futuro, coordenada por Sonia Madi, pela cessão do corpus e demais materiais.

À Prof ${ }^{a}$. Drª . Zilda Gaspar Oliveira de Aquino pelos muitos ensinamentos.

Ao Prof. Dr. Oswaldo Acursi e à Profa ${ }^{\text {. }}$ Mestre Giselle Madureira Bueno pelo aceno transformador.

Às Prof ${ }^{a}{ }^{\mathrm{s}}$. Valquíria Helena R. Guidugli, Olívia Lopes Gonçalves, Elza Maria Latorre Montagner, Paula Cristina T. Pedrosa e Mirian Mozetic pelo apoio nos momentos decisivos.

Aos meus familiares pelo carinho.

À Nina, companheira fiel e incansável.

Aos amigos que torceram por mim. 
De fato, a memória letrada, avolumando-se fatalmente com o passar do tempo, parece dar boas razões e velhas armas à metáfora do tesouro. Tudo já foi dito, inclusive esta mesma sentença.

Alfredo Bosi 
Barros, Genize Molina Zilio

Gênero Argumentativo no Ensino Fundamental I: Análise de produções de alunos participantes do Prêmio Escrevendo o Futuro-2004 / Genize Molina Zilio Barros; orientadora Norma Seltzer Goldstein. -- São Paulo, 2007. $304 \mathrm{f}$.

\section{RESUMO}

Este trabalho analisa a produção textual de alunos do Ensino Fundamental I, com idade entre 10 e 11 anos, de escolas públicas do Estado de São Paulo. Nosso corpus compõe-se de artigos de opinião classificados como semifinalistas do Prêmio Escrevendo o Futuro - 2004, promovido pelo Programa Itaú Social e pelo CENPEC Centro de Estudos e Pesquisas em Educação, Cultura e Ação Comunitária. A análise é precedida da apresentação do material de apoio ao professor, enviado às escolas participantes pelos organizadores do prêmio. Ao examinar a produção discente, buscamos avaliar as estratégias argumentativas empregadas, assim como as diferentes vozes que nela se manifestam. Nossa meta é contribuir para uma reflexão sobre o ensino da escrita, apoiado na seqüência didática e no trabalho com os gêneros discursivos.

Palavras-chave: gêneros do discurso - artigo de opinião - argumentação no E.F.I vozes verbais. 
Barros, Genize Molina Zilio

Argumentative Genre on the Ensino Fundamental I : analysis production of participating students of the Prêmio Escrevendo o Futuro-2004 / Genize Molina Zilio Barros; orientadora Norma Seltzer Goldstein. -- São Paulo, 2007.

$304 \mathrm{f}$.

\begin{abstract}
This work analyses the textual production of 10 to 11 year-old Ensino Fundamental I students, from public schools of São Paulo. In our corpus, there are opinion articles which were selected for the semifinals of the Prêmio Escrevendo o Futuro - 2004, promoted by Programa Itaú Social and by CENPEC - Centro de Estudos e Pesquisas em Educação, Cultura e Ação Comunitária. The analysis is preceeded by the teacher's support material presentation, which was sent to the involved schools by the prize responsible. By examining the students' production, we seek the evaluation of the argumentative strategies used, as well as the voices which are expressed in it. Our aim is to contribute leading to a reflection about the teaching of writing, based on the didactical sequence and on the discoursive genre subject.
\end{abstract}

Kee words: discoursives genre - opinion articles - argumentation in E.F. I - verbal voices. 


\section{SUMÁRIO}

Introdução.

\section{Capítulo I}

Contextualização Teórica

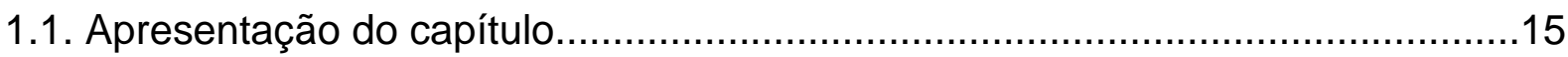

1.2. Gêneros do Discurso....................................................................... 16

1.2.1. Estudo dos gêneros e seqüências didáticas........................................21

1.3. Teorias Retórico-Argumentativas.............................................................33

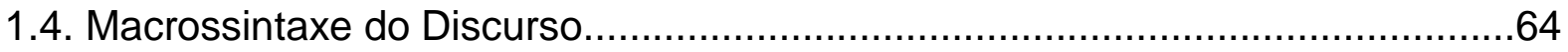

1.4.1. Os tempos verbais no discurso .........................................................67

1.4.2. Operadores argumentativos.............................................................

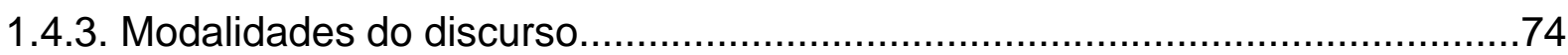

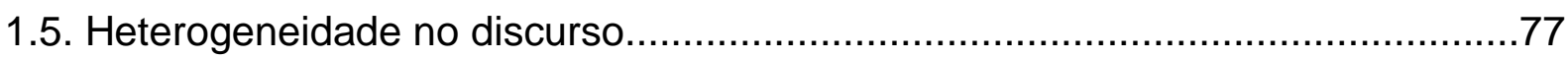

\section{Capítulo II}

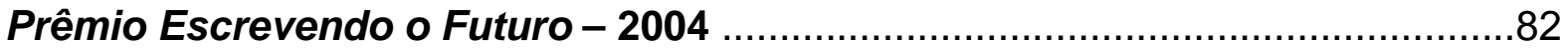

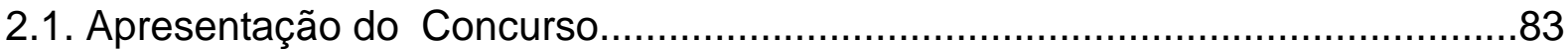

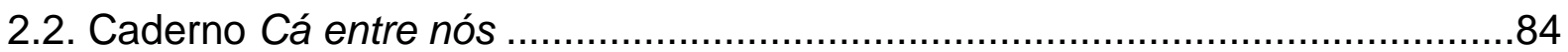

2.3. Fascículo Pontos de Vista - Texto de opinião .............................................90

2.4. Considerações sobre o material do Prêmio...................................................114

\section{Capítulo III}

Textos semifinalistas do Pólo São Paulo-. Prêmio Escrevendo o Futuro 2004

3.1. Considerações

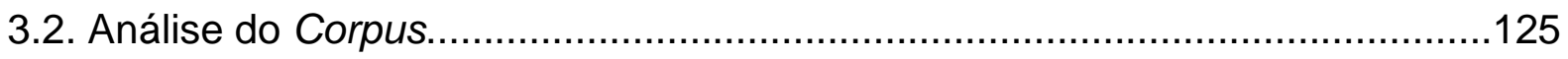

3.2.1. Ethos pré-discursivo e ethos discursivo: a busca do prestígio.....................125

3.2.2. Posicionamento do autor e intencionalidade. 
3.2.3. Tempos Verbais. 135

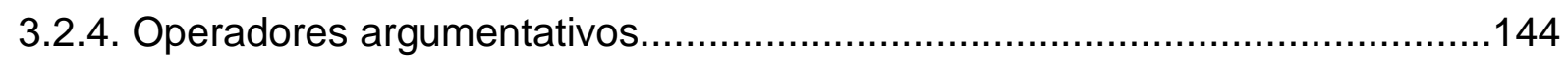

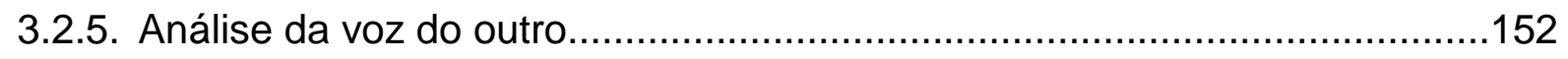

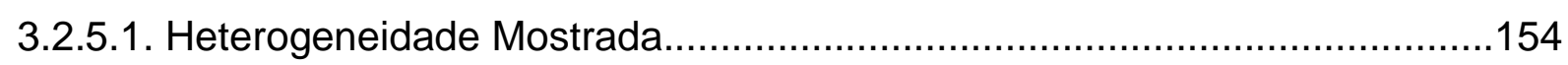

3.2.5.2. Heterogeneidade Constitutiva............................................................163

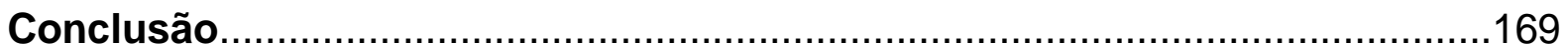

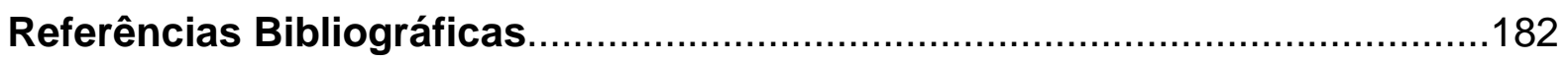

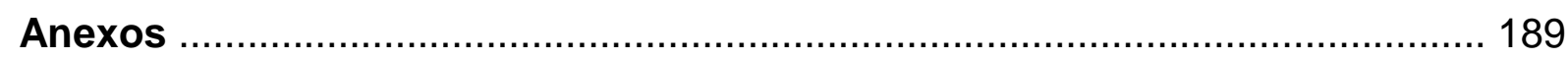




\section{ÍNDICE DOS ANEXOS}

Anexo 1 - Textos Semifinalistas do Pólo São Paulo...........................................189

1.1. Texto 9 - "Contra a sua vontade (Blackie e Rita)"......................190

1.2. Texto 32 - "Santos com ou sem o museu Pelé?" .......................192

1.3. Texto 71 - "Pensando no futuro de Amadeu Amaral" ................194

1.4. Texto 76 - "Segurança para todos" .........................................196

1.5. Texto 89 - "Café na avenida: Certo ou Errado?" ........................198

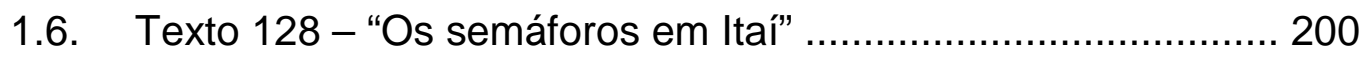

1.7. Texto 130 - "Com dinheiro não se brinca ................................202

1.8. Texto 201 - "A construção de áreas de lazer em nosso bairro".204

Apresentação dos Quadros de Análises .206

Anexo 2 - Tempos Verbais 207

Anexo 3 - Advérbios e Expressões Atitudinais; Índices de avaliação; Correção redefinição .216

Anexo 4 - Posicionamento do autor 219

Anexo 5 - Operadores Argumentativos .220

Anexo 6 - Argumentos .224

Anexo 7 - Caderno Cá entre nós.. .234

Anexo 8 - Fascículo Ponto de Vista .246 


\section{Introdução}

Este estudo pretende examinar produções de alunos de escolas públicas, realizadas no âmbito do projeto ESCREVENDO O FUTURO. Esse concurso é patrocinado pelo Programa Escrevendo o Futuro, criado pela Fundação Itaú Social que tem o objetivo de desenvolver e apoiar programas na área de Educação Pública, no Ensino Fundamental I. Conta com a coordenação técnica do Centro de Estudos e Pesquisas em Educação, Cultura e Ação Comunitária CENPEC e apoio, no conceito de parceria, do Ministério da Educação - MEC -, Conselho Nacional dos Secretários de Educação - CONSED - União Nacional dos Dirigentes Municipais da Educação - UNDIME - e do Canal Futura.

O corpus é constituído por artigos de opinião, sobre o tema "O lugar onde vivo", semifinalistas no ano de 2004 do Prêmio Escrevendo o Futuro - Pólo São Paulo.

Essas produções são o coroamento de um processo ao longo do qual ocorreram oficinas, nos moldes de seqüência didática, focadas no gênero discursivo artigo de opinião. O objetivo das oficinas era capacitar os alunos a elaborar textos com as características e linguagem próprias do gênero, para concorrer a um prêmio.

Nosso recorte volta-se para a análise das estratégias argumentativas utilizadas pelos alunos-autores, para convencer e também persuadir seus leitores, evidenciadas pelas marcas lingüísticas encontradas nos textos. Além disso, tivemos necessidade de buscar índices de heterogeneidade mostrada e heterogeneidade constitutiva, devido às vozes percebidas nos textos analisados.

A hipótese prévia é de que o projeto vem sendo seriamente conduzido e apresenta muitos pontos positivos. Mesmo assim, supõe-se que a análise 
detalhada evidencie alguns aspectos que mereçam reflexões que indiquem possível aperfeiçoamento das novas edições do projeto.

Paralelamente, num plano mais abrangente, dada a fundamentação teórica sobre argumentação apresentada adiante, existe a hipótese de que se evidenciará o quanto os processos argumentativos se manifestam na interação discursiva, mesmo em crianças de 10 ou 11 anos de idade.

Inicialmente, descrevemos e discutimos a base teórica em que apoiamos nossas análises: os estudos de Bakhtin, Schneuwly e Dolz sobre gêneros do discurso; as teorias retórico-argumentativas de Chaïm Perelman e OlbrechtsTyteca, complementadas pelos estudos de Mosca sobre Retórica; o trabalho de Koch sobre argumentação e macrossintaxe do discurso e as pesquisas de Authier-Revuz sobre heterogeneidade mostrada e heterogeneidade constitutiva.

Em um segundo momento, apresentamos o Prêmio Escrevendo o Futuro, seus objetivos, o material de apoio ao professor e as oficinas propostas.

Na seqüência, analisamos o corpus observando as características do gênero, os tipos de argumentos, as diferentes vozes e alguns recursos lingüísticos, como o emprego dos tempos verbais e operadores argumentativos.

Nas considerações finais, apresentamos um balanço dessa análise e do projeto que possibilitou a produção do corpus, indicando sugestões para seu possível aprimoramento. 
CAPÍTULO I

CONTEXTUALIZAÇÃO TEÓRICA 


\subsection{Apresentação do capítulo}

Para melhor fundamentar teoricamente nossa análise, buscaremos os estudos de Bakhtin (2004) sobre gêneros do discurso e polifonia e os trabalhos de Schneuwly e Dolz (2004) sobre gêneros do discurso e ensino da escrita por meio de seqüência didática. Trataremos das técnicas argumentativas desenvolvidas por Perelman, Ch. \& Olbrechts-Tyteca, L. (2004), complementados pelos estudos de Mosca (2004b) sobre Retórica. Também recorreremos ao trabalho desenvolvido por Koch (2004a) sobre argumentação e linguagem e às pesquisas de Authier-Revuz (1990) sobre heterogeneidade no discurso. Cabe, ainda, esclarecer que, ao longo da exposição teórica, sempre que pertinente, estabeleceremos relações entre os princípios que norteiam nosso trabalho e o objeto de nossa análise: as produções textuais dos alunos semifinalistas do Pólo São Paulo do Prêmio Escrevendo o Futuro - 2004 - que trabalharam o gênero artigo de opinião. 


\subsection{Gêneros do discurso}

A vontade discursiva do falante se realiza antes de tudo na escolha de um certo gênero de discurso.

(Bakhtin)

A classificação dos gêneros remonta à antiga Retórica e é Aristóteles quem concebe a existência de três gêneros, segundo o objetivo e o contexto. São eles: judiciário; deliberativo e epidíctico (MOSCA, 2004b, p. 31).

Conforme o objetivo a que se propõe, é de responsabilidade do orador a escolha do gênero discursivo mais apropriado que utilizará para veicular suas idéias, seu posicionamento e, por conseqüência, seus argumentos.

Mosca (2004b) apresenta-nos um quadro comparativo entre eles, analisando a finalidade de cada tipo de discurso, o tempo afetado, a categoria envolvida, o tipo de auditório, os critérios de avaliação e o argumento-tipo. Vejamos:

\begin{tabular}{|l|l|l|l|l|l|l|}
\hline Gênero & Finalidade & Tempo & Categoria & Auditório & Avaliação & Argum. tipo \\
\hline Judiciário & $\begin{array}{l}\text { Acusar/ } \\
\text { defender }\end{array}$ & Passado & Ética & $\begin{array}{l}\text { Juiz/ } \\
\text { jurados }\end{array}$ & $\begin{array}{l}\text { Justo/ } \\
\text { injusto }\end{array}$ & $\begin{array}{l}\text { entimema } \\
\text { (dedutivo) }\end{array}$ \\
\hline Deliberativo & $\begin{array}{l}\text { Aconselhar/ } \\
\text { desaconselhar }\end{array}$ & Futuro & Epistêmica & Assembléia & $\begin{array}{l}\text { Útil/ } \\
\text { prejudicial }\end{array}$ & $\begin{array}{l}\text { exemplo } \\
\text { (indutivo) }\end{array}$ \\
\hline Epidíctico & $\begin{array}{l}\text { Elogiar/ } \\
\text { censurar }\end{array}$ & Presente & Estética & espectador & $\begin{array}{l}\text { Belo/ } \\
\text { feio }\end{array}$ & amplificação \\
\hline
\end{tabular}

(MOSCA, 2004b, p. 32) 
Segundo a autora, com a multiplicação dos meios de comunicação, ocorre também uma extrema diversidade de manifestações. Ela traz algumas versões atuais de aplicação dos três tipos de discursos tratados pela velha retórica como, por exemplo: o discurso judiciário - utilizado nos tribunais, nos sermões religiosos, nos manifestos, na notas oficiais e nas cartas abertas; o discurso deliberativo empregado em documentos técnicos, discursos políticos e pronunciamentos; o discurso epidítico - freqüente em discursos comemorativos, em ocasiões solenes de caráter emotivo. Como afirma a organizadora de Retóricas de ontem e de hoje, este último procede a um elogio ou a uma censura e, ao cumprir uma função social e cívica, liga-se a questões de ética pública (MOSCA, 2004b, p. 31). Interessa-nos, em especial, a análise do gênero epidítico, pois consideramos que a ele se aparenta o artigo de opinião (lbid., p. 32).

Perelman (2005, p. 56) afirma que os discursos epidícticos constituem uma parte central da arte de persuadir, neles, "o orador procura criar uma comunhão em torno de certos valores reconhecidos pelo auditório, valendo-se do conjunto de meios de que a retórica dispõe para amplificar e valorizar" e será "[...] praticado de preferência por aqueles que, numa sociedade, defendem os valores tradicionais, os valores aceitos, os que são objeto da educação[...]" (Ibid., p.57).

Irene Machado (In: BRAIT, Beth., 2005, p. 152) afirma que, apesar de o estudo dos gêneros ter se constituído no campo da Poética e da Retórica, tal como foram formulados por Aristóteles, e o rigor de sua classificação ter se consagrado na literatura, nada teria abalado seus domínios, se não houvesse surgido a prosa. Ela passou a exigir "[...] outros parâmetros de análise das formas interativas que se realizam pelo discurso". Daí a importância de Bakhtin, pois, a partir de seus estudos, "[...] foi possível mudar a rota dos estudos sobre gêneros: além das formações 
poéticas, Bakhtin afirma a necessidade de um exame circunstanciado não apenas da retórica, mas, sobretudo, das práticas prosaicas que diferentes usos da linguagem fazem do discurso [...]"; em seu estudo sobre gêneros discursivos, o autor considera não a classificação das espécies, mas o dialogismo do processo comunicativo. Machado completa: "mais do que reverter o quadro tipológico das criações estéticas, o dialogismo, ao valorizar o estudo dos gêneros, descobriu um excelente recurso para 'radiografar' o hibridismo, a heteroglossia e a pluralidade de sistemas de signos na cultura" (lbid., p. 153).

Essas afirmações confirmam a importância de trazer para as nossas reflexões o trabalho de Mikhail Bakhtin (2003). O autor afirma que todos os diversos campos da atividade humana estão ligados ao uso da linguagem, portanto, as formas desse uso são tão multiformes quanto os campos da atividade humana. Considera que o dialogismo faz parte do processo comunicativo, pois "[...] o ouvinte, ao perceber e compreender o significado [lingüístico] do discurso, ocupa simultaneamente em relação a ele uma ativa posição responsiva: concorda ou discorda dele [total ou parcialmente], completa-o, aplica-o, prepara-se para usá-lo [...]" (Ibid., p. 271). Dessa forma, a interação produz efeito de sentido, já que o sentido é constituído por diferentes realizações discursivas. Em conseqüência, qualquer ato discursivo, por si só, já pressupõe um gênero, que são "tipos relativamente estáveis de enunciados", isto é, "[...] todos os nossos enunciados possuem formas relativamente estáveis e típicas de construção do todo", falamos apenas através de determinados gêneros (Ibid., p. 282, grifo do autor). Segundo ele, até mesmo no bate-papo mais descontraído, nós moldamos nosso discurso por determinadas formas de gêneros, que nos são dados quase da mesma forma como nos é dada a língua materna. 
Para ele, gêneros primários são os considerados espontâneos que "[...] se formam na comunicação discursiva imediata", nos diálogos do cotidiano. Gêneros secundários são os que "[...] surgem nas condições de um convívio cultural mais complexo [...], (predominantemente o escrito)", como as enunciações da vida pública, institucional, artística, científica e filosófica, "no processo de sua formação eles incorporam e reelaboram diversos gêneros primários[...]" (Ibid., p. 263). Segundo ele "a riqueza e a diversidade de gêneros do discurso são infinitas[...]", porque são inesgotáveis as possibilidades da atividade humana. Cada ato de comunicação pressupõe um gênero, sua escolha reflete as condições específicas de cada campo da atividade humana pelo conteúdo temático, pelo estilo e pela linguagem - seleção dos recursos lexicais e fraseológicos da língua - e, "[...] acima de tudo, por sua construção composicional” (Ibid., p. 262 - 261).

O teórico afirma que o emprego da língua efetua-se por meio de enunciados concretos e únicos, tanto orais como escritos: "[...] a língua passa a integrar a vida através de enunciados concretos (que a realizam); é igualmente através de enunciados concretos que a vida entra na língua". Considera que toda investigação de um material lingüístico concreto opera com enunciados concretos relacionados a essas atividades e que em qualquer corrente de estudo "[...] faz-se necessária uma noção precisa da natureza do enunciado em geral e das particularidades dos diversos tipos de enunciados (primários e secundários), isto é, dos diversos gêneros do discurso" (lbid., p. 265 -264).

Assegura que muitas pessoas que dominam muito bem a língua sentem-se impotentes em alguns campos da comunicação, porque não dominam as formas de gênero de dadas esferas. Esclarece que "quanto melhor dominarmos os gêneros mais livremente os empregamos, tanto mais plena e nitidamente descobrimos neles 
a nossa individualidade [...] refletimos de modo mais flexível e sutil a situação singular da comunicação [...]"(lbid., p. 285).

Segundo essa proposta, o gênero em estudo, artigo de opinião, tem de apresentar conteúdo temático, estilo e linguagem próprios desse gênero argumentativo. No momento da análise, esses aspectos serão levados em conta. 


\subsubsection{Estudo dos gêneros e seqüências didáticas}

Pode parecer que a heterogeneidade dos gêneros discursivos é tão grande que não há nem pode haver um plano único para seu estudo [...]

(Bakhtin)

À luz do conceito bakhtiniano de gênero discursivo, pesquisadores europeus do chamado "Grupo de Genebra", dentre os quais Pasquier e Dolz (1996) e Schneuwly e Dolz $(2004)^{1}$, desde a última década do século $X X$, têm proposto práticas pedagógicas voltadas ao desenvolvimento da competência comunicativa dos alunos. Atualmente, estão envolvidos numa pesquisa que realizam, na Suíça francófona, sobre diferentes temas da didática do francês língua materna, tais como a transposição didática de objetos discursivos e gramaticais em sala de aula.

Esses autores fundamentam seus estudos na teoria interacionista de Vygotsky, na teoria enunciativa e na lingüística textual, "[...] cujos enfoques teóricos dirigem o ensino da língua(gem) para seu uso e funcionamento discursivos[...]" (Lopes-Rossi, 2002, p. 24). Consideram o gênero um instrumento que se encontra entre o indivíduo que age e o objeto sobre o qual ele age. $\mathrm{O}$ instrumento [gênero] torna-se o lugar privilegiado da transformação dos comportamentos que, para tornar-se mediador, "[...] precisa ser apropriado pelo sujeito; ele não é eficaz senão à medida que se constroem, por parte do sujeito, os esquemas de sua utilização" (SCHNEUWLY; DOLZ, 2004, p. 24).

No que diz respeito às práticas de linguagem, sua apropriação pela criança começa na família, na troca verbal espontânea, por meio dos gêneros primários.

\footnotetext{
${ }^{1}$ Bernard Schneuwly e Joaquim Dolz são professores e pesquisadores em Didática do Francês/ Língua Materna, da Faculdade de Psicologia e Ciências da Educação (FASE) da Universidade de Genebra (Unige), Suíça. Schneuwly é coordenador do Grupo Grafe - Grupo Romando de Análise do Francês Ensinado, do qual Dolz também faz parte.
} 
Estes, por sua vez, são os instrumentos de criação dos gêneros secundários que se apóiam totalmente nos primários, transformando-os profundamente, dessa forma "os gêneros se complexificam e tornam-se instrumentos de construções novas, mais complexas" (Ibid., p. 30 et seq.). São apropriados e desenvolvidos, na escola, por meio de uma aprendizagem intencional, ou seja, a escola é tomada como autêntico lugar de comunicação e as situações escolares, como ocasiões de produção/ recepção de textos (lbid., p. 78).

Postulam que a comunicação oral ou escrita pode e deve ser ensinada sistematicamente, por meio de uma estratégia chamada seqüência didática. Esclarecem que “ ‘uma seqüência didática’ é um conjunto de atividades escolares organizadas, de maneira sistemática, em torno de um gênero textual oral ou escrito". Sua finalidade é ajudar o aluno a dominar melhor um gênero de texto que ele não domina ou o faz de maneira insuficiente, "[...] permitindo-lhe, assim, escrever ou falar de uma maneira mais adequada numa dada situação de comunicação" (lbid., p. 97).

\section{Estrutura da seqüência didática}

Schneuwly e Dolz (2004, p. 98) representam a seqüência didática pelo seguinte esquema:

Apresentação da situação

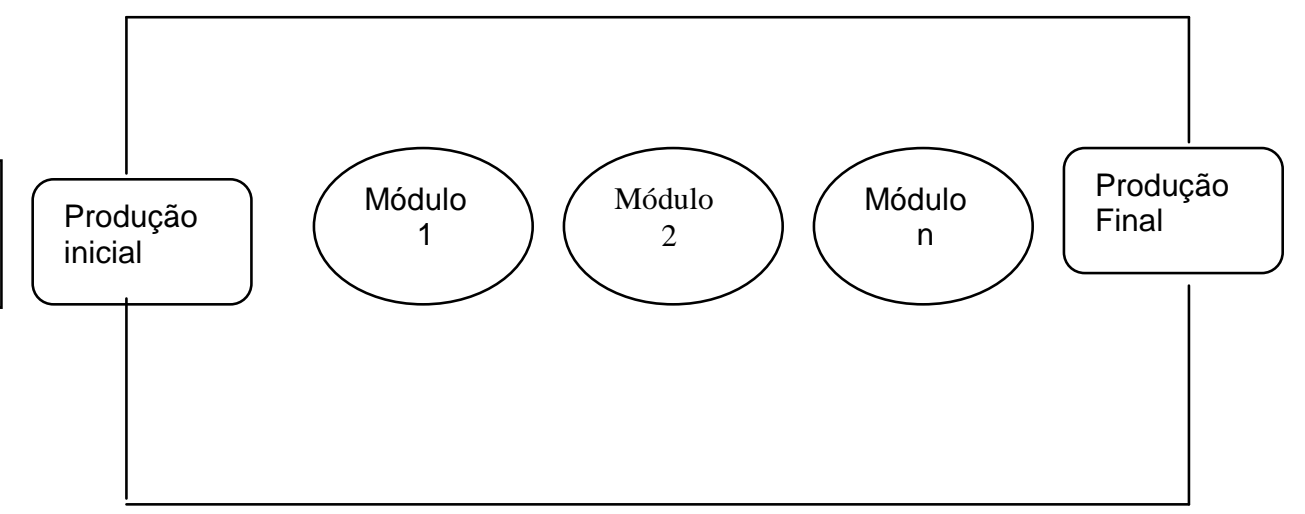


Primeiramente, faz-se uma apresentação da situação em que se descreve, de maneira detalhada, a tarefa que os alunos deverão realizar. É o momento em que os alunos constroem uma representação da situação de comunicação e da atividade de linguagem a ser executada. Duas dimensões podem ser distinguidas:

1) Apresentar um problema de comunicação bem definido

Os autores esclarecem que a primeira dimensão é a do projeto coletivo de produção do gênero, que deve ser proposto de maneira bastante explícita e dar as indicações que respondam às seguintes questões:

- Qual é o gênero que será elaborado? [sugerem que leiam ou escutem um exemplo do gênero visado para esclarecer as representações dos alunos.]

- A quem se dirige a produção?

- Que forma assumirá a produção? [gravação em áudio ou vídeo, carta, folheto, representação etc.]

- Quem participará da produção? [todos os alunos, alguns, individualmente, em grupo etc.]

2) Preparar os conteúdos dos textos que serão produzidos

Os alunos devem perceber a importância do conteúdo e saber com quais irão trabalhar. Os autores exemplificam, dizendo que, se o texto for uma carta de leitor, os alunos deverão conhecer bem a questão colocada e os argumentos a favor e contra as diferentes posições. Observam, também, que esse projeto pode ser 
“[...] parcialmente fictício, à medida que a motivação pode nascer mais diretamente do desejo de progredir, de adquirir novas capacidades" (Ibid., p. 101).

Após a "Apresentação da Situação", a próxima etapa é a elaboração de um primeiro texto inicial, oral ou escrito, que o aluno suponha corresponder ao gênero trabalhado: é a primeira produção. O aluno é colocado, desde o primeiro momento, "[...] em face a uma tarefa complexa e global, de maneira semelhante ao que acontece nas atividades autênticas de comunicação" (PASQUIER; DOLZ, 1996). Essa etapa permite ao professor avaliar as capacidades já adquiridas e ajustar as atividades e os exercícios previstos na seqüência às possibilidades e dificuldades reais de uma turma. Para os autores "[...] essa é a essência da avaliação formativa". Essas produções, que não receberão nota, "[...] constituem momentos privilegiados de observação, que permitem refinar a seqüência, modulá-la e adaptá-la de maneira mais precisa às capacidades reais dos alunos de uma dada turma" (SCHNEUWLY; DOLZ, 2004, p.101-102).

Os módulos, constituídos por várias atividades ou exercícios, subsidiam os alunos, dando-lhes os instrumentos necessários para dominar o gênero em questão, trabalhando os problemas detectados na primeira produção de maneira sistemática e aprofundada. Esclarecem que o movimento geral da seqüência didática vai, portanto, do complexo para o mais simples: da produção inicial aos módulos, cada um trabalhando uma ou outra capacidade necessária para o domínio geral do gênero e, que, na etapa conclusiva, o movimento leva novamente ao complexo: a produção final.

Os pesquisadores apresentam três questões quanto ao encaminhamento de decomposição do trabalho sobre os problemas: 1) Que dificuldades da expressão 
oral ou escrita abordar?; 2) Como construir um módulo para trabalhar um problema particular?; 3) Como capitalizar o que é adquirido nos módulos?

Quanto ao primeiro aspecto, afirmam que o aluno deve aprender a fazer a imagem, a mais exata possível, do destinatário do texto, do gênero visado, de sua finalidade e de sua posição como locutor ou autor. Além disso, o aluno deve conhecer as técnicas para buscar, elaborar ou criar conteúdos, ação que difere muito em função dos gêneros, como também difere o planejamento da estrutura do texto e da linguagem mais eficaz a ser utilizada.

Quanto ao segundo aspecto, sugerem que as atividades propostas, em cada módulo, devem ser "[...] as mais diversificadas possível, dando, assim, a cada aluno a possibilidade de ter acesso, por diferentes vias, às noções e aos instrumentos, aumentando, desse modo, suas chances de sucesso" (Ibid., p. 105). Distinguem três grandes categorias de atividades e de exercícios:

a) Atividades de observação e de análise de textos: ponto de referência indispensável a toda aprendizagem eficaz da expressão, pode-se ler textos completos ou parte deles, compará-los etc;

b) Tarefas simplificadas de produção de textos: possibilita a concentração particular em um aspecto preciso da elaboração de um texto, permitindo descartar certos problemas de linguagem;

c) Elaboração de uma linguagem comum: para poder falar dos textos, comentá-los, criticá-los, melhorá-los.

Quanto ao terceiro aspecto, relativo à capitalização das aquisições, os estudiosos afirmam que a aquisição de um vocabulário técnico construirá, progressivamente, conhecimentos sobre o gênero trabalhado, associando-se a isso 
a construção de um registro dos conhecimentos adquiridos, durante o trabalho nos módulos, como listas de constatações, lembretes ou glossário.

No momento da produção final, o aluno pode pôr em prática os conhecimentos adquiridos, separadamente, nos módulos. Essa produção permite, também ao professor, realizar uma avaliação somativa que incidirá, de maneira explícita, sobre os aspectos trabalhados durante a seqüência; essa avaliação "[...] orienta os professores para uma atitude responsável, humanista e profissional" (lbid., p. 108). Também indicará para o aluno os objetivos atingidos e o que resta fazer, servirá de instrumento para regular e controlar seu próprio comportamento de produtor de textos durante a revisão e a reescrita, além de permitir-lhe avaliar os progressos realizados.

Seguem-se algumas reflexões, orientações e esclarecimentos sobre alguns pontos que consideram cruciais no procedimento "seqüência didática": escolhas pedagógicas; escolhas psicológicas; escolhas lingüísticas e finalidades gerais.

Sobre as escolhas pedagógicas, afirmam que a possibilidade de avaliação formativa regula o processo de ensino e de aprendizagem e que o procedimento se insere num projeto que motiva os alunos a escrever, além de maximizar, pela diversificação das atividades e dos exercícios, as chances de cada aluno se apropriar dos gêneros.

Sobre as escolhas psicológicas, consideram que o procedimento visa a transformar o modo de falar e de escrever dos alunos e que essa transformação ocorre porque diferentes instrumentos de linguagem são propostos, incluindo-se o fato de que a atividade de produção de textos é trabalhada em toda a sua complexidade, isto é, não somente como colocação de palavras em frases expressando idéias prévias, mas de maneira que transforme o modo de falar e de 
escrever dos alunos, no sentido de uma consciência mais ampla de seu comportamento de linguagem em todos os níveis.

Sobre as escolhas lingüísticas, asseveram que toda língua se adapta às situações de comunicação e funciona de maneira bastante diversificada e que "há formas históricas relativamente estáveis de comunicação [...] correspondendo a situações de comunicação típicas, a saber, os gêneros de textos. Estes últimos definem o que é 'dizível' através de quais estruturas e com que meios lingüísticos" (lbid., p. 109).

Essa afirmação responde à expectativa criada por Bakhtin (2003, p. 262), ao dizer que "pode parecer que a heterogeneidade dos gêneros discursivos é tão grande que não há nem pode haver um plano único para seu estudo [...]", epígrafe deste sub-capítulo, ilustrando o grupo de Genebra que nos apresenta um caminho para o ensino dos gêneros discursivos. Como se sabe, a mesma trilha é sugerida pelos PCNs de língua portuguesa (1997/1998), em que "passam a ter importância considerável tanto as situações de produção e de circulação dos textos como a significação que nelas é forjada" (SCHNEUWLY; DOLZ, 2004, p. 11). Neles, "[...] convoca-se a noção de gêneros [discursivos ou textuais] como um instrumento melhor que o conceito de tipo para favorecer o ensino de leitura e de produção de textos escritos e, também, orais (Ibid., p. 11).

Sobre as finalidades gerais, dizem que os procedimentos descritos concretizam as seguintes finalidades: preparar os alunos para dominar sua língua nas situações mais diversas da vida cotidiana; desenvolver uma relação consciente e voluntária com seu comportamento de linguagem e construir nos alunos uma representação da atividade de escrita e de fala em situações complexas. 
Complementam, dizendo que a perspectiva adotada nas seqüências é uma perspectiva textual, o que implica levar em conta os diferentes níveis do processo de elaboração de textos como: marcas de organização características de um gênero; elementos de responsabilidade enunciativa e de modalização dos enunciados e emprego dos tempos verbais característicos.

Já o domínio de gramática, sintaxe e ortografia não está ligado a um gênero preciso. Ele passa pela compreensão e pela apropriação das regras gerais da língua e necessita de conhecimentos explícitos sobre seu funcionamento ${ }^{2}$. Trata-se de desenvolver, nos alunos, capacidades de análise que lhes permitam melhorar esses conhecimentos, para tanto é preciso reservar tempo para um ensino específico. A bagagem que terão acumulado, ao longo desses momentos de reflexão específica, poderá ser reinvestida, com proveito, nas tarefas de escrita e de revisão previstas nas seqüências, que apesar de constituírem momento de intersecção entre as atividades de expressão e de estruturação, não "[...] podem assumir a totalidade do trabalho necessário para levar os alunos a um melhor domínio da língua e devem apoiar-se em certos conhecimentos, construídos em outros momentos" (Ibid., p. 114).

Afirmam que cada gênero necessita de um ensino adaptado, pois apresenta características distintas, no entanto, afirmam que os gêneros podem ser agrupados em função de certo número de regularidades lingüísticas, e que uma progressão "em espiral” permite um melhor domínio do mesmo gênero em diferentes níveis. Dessa forma, em cada nível [ciclos/ séries], o aluno terá exercitado a produção de gêneros pertencentes a diversos agrupamentos. Reforçam que a repetição dos mesmos gêneros a cada ano não se justifica, porém a retomada de objetivos já

\footnotetext{
${ }^{2}$ Referência a atividades de caráter epilingüístico. [N.T.]
} 
trabalhados, após um certo espaço de tempo, e numa nova perspectiva, é indispensável para solidificar a aprendizagem.

Além disso, asseguram que "a escolha dos gêneros tratados de acordo com os ciclos/ séries justifica-se pela idéia de que a aprendizagem não é uma conseqüência do desenvolvimento, mas uma condição para ele" (lbid., p. 124). Deve-se considerar, segundo os autores, que a aprendizagem é lenta e longa e que, para assegurar o domínio dos principais gêneros, no final do ensino fundamental, propõe-se uma iniciação precoce, com objetivos adaptados às primeiras etapas.

Sobre a gestão do ensino, no que diz respeito à duração da seqüência, Pasquier, A. e Dolz, J. (1996, p. 05) afirmam que as investigações realizadas mostram que um ensino "concentrado", num período de tempo, dá melhores resultados. As aprendizagens que o aluno realiza são mais eficazes, duráveis e profundas, se o trabalho ocorrer de maneira intensiva, concentrado, num período breve, de não mais do que duas ou três semanas.

Justificam, apresentando as seguintes razões: 1) quando as atividades orientadas para um mesmo objetivo sucedem-se cotidianamente, há menos perda por esquecimento e pode-se assegurar melhor a continuidade na aprendizagem; no caso de interrupção, o efeito demonstrou-se contrário; 2) toda aprendizagem supõe uma consciência clara, por parte do aprendiz, do que faz, de por que o faz; para onde se dirige; e que não pode ser mantida indefinidamente. Observam que "acima de uma, duas ou três semanas [...] os alunos não só perdem o interesse, mas também já não sabem muito bem por que razões estão fazendo as atividades e os exercícios [...]" (Ibid., p. 06). Os autores utilizam os termos cansaço, desatenção e desinteresse para designar essa atitude dos alunos. Esse ponto nos importa pelo 
fato de, em capítulo posterior, refletirmos sobre a duração da seqüência didática proposta pelo Prêmio Escrevendo o Futuro.

Feitas essas considerações, apresentamos o quadro com os agrupamentos de gêneros, propostos pelos autores (Ibid., p. 121):

ASPECTOS TIPOLÓGICOS

\begin{tabular}{|c|c|c|}
\hline $\begin{array}{l}\text { DOMÍNIOS SOCIAIS DE } \\
\text { COMUNICAÇÃO }\end{array}$ & $\begin{array}{l}\text { CAPACIDADES DE } \\
\text { LINGUAGEM } \\
\text { DOMINANTE }\end{array}$ & $\begin{array}{l}\text { EXEMPLOS DE GÊNEROS } \\
\text { ORAIS E ESCRITOS }\end{array}$ \\
\hline $\begin{array}{l}\text { Cultura literária } \\
\text { ficcional }\end{array}$ & $\begin{array}{l}\text { NARRAR } \\
\text { Mimeses da ação através } \\
\text { de intriga }\end{array}$ & $\begin{array}{l}\text { Conto maravilhoso } \\
\text { Fábula } \\
\text { Lenda } \\
\text { Narrativa de aventura } \\
\text { Narrativa de ficção científica } \\
\text { Narrativa de enigma } \\
\text { Novela fantástica } \\
\text { Conto parodiado }\end{array}$ \\
\hline $\begin{array}{l}\text { Documentação e } \\
\text { memorização de } \\
\text { ações humanas }\end{array}$ & $\begin{array}{l}\text { RELATAR } \\
\text { Representação pelo discurso } \\
\text { de experiências vividas, } \\
\text { situadas no tempo }\end{array}$ & $\begin{array}{l}\text { Relato de experiência vivida } \\
\text { Relato de viagem } \\
\text { Testemunho } \\
\text { Curriculum vitae } \\
\text { Notícia } \\
\text { Reportagem } \\
\text { Crônica esportiva } \\
\text { Ensaio biográfico }\end{array}$ \\
\hline $\begin{array}{l}\text { Discussão de } \\
\text { problemas sociais } \\
\text { controversos }\end{array}$ & $\begin{array}{l}\text { ARGUMENTAR } \\
\text { Sustentação, refutação } \\
\text { e negociação de } \\
\text { tomadas de posição }\end{array}$ & $\begin{array}{l}\text { Texto de opinião } \\
\text { Diálogo argumentativo } \\
\text { Carta do leitor } \\
\text { Carta de reclamação } \\
\text { Deliberação informal } \\
\text { Debate regrado } \\
\text { Discurso de defesa (adv.) } \\
\text { Discurso de acusação (adv.) }\end{array}$ \\
\hline
\end{tabular}


ASPECTOS TIPOLÓGICOS

\begin{tabular}{|c|c|c|}
\hline $\begin{array}{c}\text { DOMÍNIOS } \\
\text { SOCIAIS DE } \\
\text { COMUNICAÇÃO }\end{array}$ & $\begin{array}{l}\text { CAPACIDADES DE } \\
\text { LINGUAGEM } \\
\text { DOMINANTE }\end{array}$ & $\begin{array}{l}\text { EXEMPLOS DE GÊNEROS } \\
\text { ORAIS E ESCRITOS }\end{array}$ \\
\hline $\begin{array}{l}\text { Transmissão } \\
\text { e construção }\end{array}$ & $\begin{array}{l}\text { EXPOR } \\
\text { Apresentação textual de } \\
\text { diferentes } \\
\text { formas dos saberes }\end{array}$ & $\begin{array}{l}\text { Seminário } \\
\text { Conferência } \\
\text { Artigo ou verbete de enciclopédia } \\
\text { Entrevista de especialista } \\
\text { Tomada de notas } \\
\text { Resumo de textos "expositivos" ou } \\
\text { explicativos } \\
\text { Relatório científico } \\
\text { Relato de experiência científica }\end{array}$ \\
\hline $\begin{array}{l}\text { Instruções } \\
\text { e prescrições }\end{array}$ & $\begin{array}{l}\text { DESCREVER AÇÕES } \\
\text { Regulação mútua de } \\
\text { comportamentos }\end{array}$ & $\begin{array}{l}\text { Instruções de montagem } \\
\text { Receita } \\
\text { Regulamento } \\
\text { Regras do jogo } \\
\text { Instruções de uso } \\
\text { Instruções }\end{array}$ \\
\hline
\end{tabular}

Apresentada a concepção de ensino de língua materna baseada nos estudos sobre gêneros e seqüências didáticas, reconhecemos o valor desse novo caminho e dessa nova perspectiva, em prol dos trabalhos de desenvolvimento da oralidade e da escrita na escola, porque postulamos com Lopes-Rossi (2002, p.20) ao afirmar que as condições de escrita na escola, fora desta proposta, correm o risco de ser inadequadas por: artificialidade das situações de redação; falta de finalidade do texto, a não ser cumprir uma exigência do professor; descaracterização do uso da linguagem; artificialidade dos temas propostos; falta de motivação de escrita por parte do aluno; falta de um real leitor para o seu texto [exceto o professor]; falta de acompanhamento do professor ao longo das várias etapas de elaboração do texto. Acreditamos que é necessária uma mudança de concepção no ensino e na 
aprendizagem da produção escrita na escola, sendo este 0 momento e esse, 0 caminho. 


\subsection{As teorias retórico-argumentativas}

[...] a teoria da argumentação visa, através do discurso, a obter uma ação eficaz sobre os espíritos [...]

(Perelman e Olbrechts-Tyteca)

Mosca (2004b, p. 27) afirma que "para Ducrot e Ascombre, a argumentação se inscreve na própria língua, dada a natureza argumentativa da linguagem", de modo particular, nos textos especificamente argumentativos. Antes de nos debruçarmos sobre as análises do artigo de opinião, parece oportuno percorrer as teorias argumentativas desenvolvidas por Perelman e Olbrechts-Tyteca (2005), baseadas na Retórica de Aristóteles - inspiração para a Nova Retórica.

No prefácio à edição brasileira do Tratado da Argumentação - A Nova Retórica (2005), Fábio Ulhoa Coelho afirma ser instigante como algumas idéias importantes, esmaecidas ao longo da história, ressurgem vigorosas e renovadas em contexto histórico diverso. É o caso da noção aristotélica de dialética. Os dois modos básicos de raciocinar propostos por Aristóteles, demonstração analítica e argumentação dialética, não foram desenvolvidos e explorados na mesma medida. O primeiro, segundo Coelho, "[...] se traduz numa demonstração fundada em proposições evidentes, que conduz o pensamento à conclusão verdadeira [...]" onde se alicerça "[...] a lógica formal; o outro se expressa através de um argumento sobre enunciados prováveis, dos quais se poderiam extrair conclusões apenas verossímeis [...]" (PERELMAN; OLBRECHTS- TYTECA, 2005: XI). Apesar de, ao longo da história, observarmos uma desvalorização deste último, o prefaciador afirma que não se nota, no pensamento aristotélico, nenhuma hierarquização entre essas duas maneiras e que vinte e três séculos foram necessários para que houvesse um 
resgate da idéia dialética, por meio dos estudos feitos por Perelman e OlbrechtsTyteca.

Chaïm Perelman e Lucie Olbrechts-Tyteca ${ }^{3}$, em seu Tratado da Argumentação - A Nova Retórica (2005), refletem sobre a teoria argumentativa, considerando as questões retóricas como fundamentais para a finalidade do convencimento e da persuasão, uma vez que só o uso da lógica não seria suficiente para dar conta da ação de argumentar, pois, além da razão, temos as emoções, os valores, as preferências. Quando se trata de argumentar e de influenciar o outro por meio do discurso, não é possível menosprezar as condições psíquicas e sociais do auditório, sem as quais a argumentação ficaria sem um objetivo e sem nenhum efeito.

Segundo Mosca (2004b, p. 46-47), "a Retórica dilata a extensão de seu campo para toda manifestação discursiva que visa à adesão do ouvinte/ leitor, podendo-se dizer que todo discurso que não aspira a uma validade impessoal depende necessariamente da retórica". Ela não é simplesmente uma techne a exigir cultivo e arte, mas uma visão de vida que implica tomada de posição, ação no mundo. A autora reforça que fatos atuais que ocupam importante espaço, como o dos Direitos Humanos, em suas múltiplas formas e ocorrências, "[...] por si sós já deixam patentes a vitalidade da Retórica, enquanto proposta de caminhos e alternativas, para os quais se buscam os meios eficientes de convencimento e de expressão" .

Exemplificaremos as afirmações de Mosca (2004b) sobre a extensão dos campos da Nova Retórica, seu intercâmbio com outras disciplinas das Ciências da

\footnotetext{
${ }^{3}$ Daqui por diante, por serem muitas as referências feitas aos dois autores do livro Tratado da Argumentação. A Nova Retórica, será nomeado somente o primeiro autor, Perelman.
} 
Linguagem e a importância dos estudos das técnicas argumentativas desenvolvidas por Perelman - já que seu uso se justifica pela interação, pela necessidade de adesão -, estabelecendo uma relação com os estudos feitos por pesquisadores da Análise da Conversação - AC.

Lembremos os estudos feitos por Luiz Antônio Marcuschi (1999, p. 284, apud SILVA, 1999, p. 109). O autor afirma que a conversação, por ser uma atividade em que se desenvolvem negociações permanentes entre indivíduos, custa trabalho e exige altruísmo. Essa afirmação indica que a argumentação está presente nas negociações permanentes desenvolvidas em todas as atividades comunicacionais.

Mosca (2004b, p. 17) assevera que, partindo-se do princípio de que a argumentatividade está presente em toda e qualquer atividade discursiva, tem-se também o fato de que argumentar significa considerar o outro como capaz de reagir e de interagir diante das teses que lhe são apresentadas, "[...] tendo-se uma verdadeira arena em que os interesses se entrechocam, quando o clima é de negociação, e em que prevalece o anseio de influência do poder".

O objeto da teoria perelmaniana é o estudo das técnicas argumentativas que permitem obter a adesão dos espíritos às teses que se lhes apresentam ao assentimento. O autor afirma que as mesmas técnicas de argumentação utilizadas nas discussões ao redor da mesa familiar são usadas em um debate em um meio muito especializado (PERELMAN; OLBRECHTS- TYTECA, 2005).

Koch (2004a, p. 17-18), na mesma linha de reflexão, confirma a característica argumentativa da comunicação, defendendo que "a interação social por intermédio da língua caracteriza-se fundamentalmente pela argumentatividade". Ressalta que o homem é um ser dotado de razão e vontade, ele julga, avalia, critica, ou seja, forma juízos de valor. Sua ação verbal é dotada de intencionalidade. Para 
ela, argumentação e retórica são "quase sinônimos", ocorrendo a presença de ambas, em maior ou em menor grau, em todo e qualquer tipo de discurso.

Conforme Mosca (2004b, p. 22- 26), "[...] o ato de informar não existe em estado puro e serve antes a convencer e persuadir do que por si próprio. É a ação sobre os espíritos por meio do discurso. Discurso persuasivo, portanto, é "[...] destinado a agir sobre os outros através do logos (palavra, razão), ele envolve a disposição que os ouvintes conferem aos que falam (ethos) e a reação a ser desencadeada nos que ouvem (pathos)" ${ }^{\prime 4}$ (Ibid., p. 22). Esses três elementos, para Perelman, já são os argumentos.

Ao utilizar técnicas argumentativas, o autor belga julga de fundamental importância, em uma situação comunicacional dialógica, a consideração do outro, a alteridade deliberativa, se a intenção for promover a adesão do interlocutor, por meio do convencimento, da persuasão.

Para a Nova Retórica, a distinção entre os termos "convencer" e "persuadir" é primordial. O ato de convencer se dirige unicamente à razão, por meio de um raciocínio lógico e de provas objetivas. É capaz, portanto, de atingir um "auditório universal". Seu caráter é demonstrativo e atemporal. Já o ato de persuadir procura atingir a vontade, o sentimento do outro [ouvinte/ leitor], por meio de argumentos verossímeis. Seu caráter é ideológico, subjetivo e temporal, procura atingir um "auditório particular" (KOCH, 2004a, p. 18).

Propomo-nos chamar 'persuasiva' a uma argumentação que pretende valer só para um auditório particular e chamar 'convincente' àquela que deveria obter a adesão de todo ser racional (PERELMAN; OLBRECHTS- TYTECA, 2005, p. 31).

\footnotetext{
${ }^{4}$ Para Aristóteles "as provas fornecidas pelo discurso são de três espécies: a primeira encontra-se no ethos do orador, a segunda, no fato de colocar o ouvinte em certa disposição, a terceira, no próprio discurso (logos), uma vez que ele demonstra ou parece demonstrar" (Cf. AMOSSY, 2005, p. 40).
} 
Perelman (2005) sustenta que, para quem está preocupado com o caráter racional da adesão, convencer é mais do que persuadir. Já, para quem se preocupa com o resultado, persuadir é mais do que convencer, pois a convicção não passa da primeira fase que leva à ação. Cita Rousseau, filósofo para quem "de nada adianta convencer uma criança, 'se não se sabe persuadi-la'” (Ibid., p. 30).

Acreditando que "a escolha dos termos, para expressar o pensamento, raramente deixa de ter alcance argumentativo" e que "não existe escolha neutra" (PERELMAN; OLBRECHTS- TYTECA, 2005, p.168 - 169), encontramos diversos momentos em que são analisadas as escolhas lexicais e a força persuasiva que elas possuem dentro do discurso.

Afirma que "para discernir o uso argumentativo de um termo, é importante, pois, conhecer as palavras ou expressões de que o orador poderia ter se servido e às quais preferiu a palavra utilizada". O conjunto de locuções disponíveis, família de palavras $^{5}$, não são ligadas por um sistema de derivações, mas por expressões aparentadas pelo sentido e "[...] são, de certo modo, o fundo contra o qual se destaca o termo utilizado" (Ibid., p. 170).

O próprio filósofo belga assevera: "nosso tratado só versará sobre recursos discursivos para se obter a adesão dos espíritos: apenas a técnica que utiliza a linguagem para persuadir e convencer será examinada[...]". Em outro momento, reforça essa afirmação dizendo que " a linguagem não é somente meio de comunicação, é também instrumento de ação sobre as mentes, meio de persuasão" (PERELMAN; OLBRECHTS- TYTECA, 2005, p. 8 - 149).

As mesmas questões são encontradas no trabalho de Koch (2004a) para quem as análises desses recursos lingüísticos interessam enquanto marcas

\footnotetext{
${ }^{5} \mathrm{O}$ autor esclarece emprestar a terminologia dos significistas holandeses.
} 
argumentativas, utilizadas pelo enunciador, para promover a adesão do enunciatário, são as marcas lingüísticas relativas ao modo como é produzido o discurso e que constituem as diversas modalidades da enunciação. Segundo a autora, essas relações discursivas - ideológicas ou argumentativas - relacionadas à intencionalidade do falante, estabelecidas entre enunciado e enunciação são detectadas por meio de uma gramática textual ou macrossintaxe do discurso trabalho que será analisado mais detidamente em capítulo posterior.

Rocco (1989, p. 53) observa que a aplicação das teorias perelmanianas são fundamentais na análise de textos, pois "[...] muitas de suas proposições teóricas constituem-se, elas próprias, em critérios para uma compreensiva análise textual”.

Além da escolha dos termos, para o autor das teorias argumentativas, as modalidades que empregamos para expressar nosso pensamento mudam a realidade. Segundo ele, no sentido técnico do lingüista, as modalidades são em número de quatro: assertiva; injuntiva; interrogativa e optativa.

A modalidade assertiva é conveniente em qualquer argumentação. A injuntiva expressa-se pelo imperativo e é eficaz para aumentar o sentimento de presença, fator essencial da argumentação, pois atua de modo direto sobre a nossa sensibilidade. Exemplifica essa modalidade, afirmando que o locutor de uma competição esportiva, ao prescrever aos jogadores fazerem isto ou aquilo, comunica indiretamente um juízo sobre sua coragem ou sobre sua hesitação que "[...] dão à cena um alto grau de presença, devido ao fato de que quem fala parece participar da ação que descreve" (PERELMAN; OLBRECHTS- TYTECA, 2005, p. 179).

O modo interrogativo tem uma importância retórica considerável, porque além de aumentar o sentimento de presença do objeto - responder a uma pergunta é 
confirmar o acordo implícito sobre a existência do objeto -, em geral, é uma forma hábil para encetar raciocínios, com a cumplicidade do interlocutor, pois ao responder, ele adota esse mesmo argumento.

A modalidade optativa, para ele, talvez seja a que melhor se presta à expressão das normas. "A ação de voto 'tomara que ele consiga'[...]" exprime uma aprovação e, indiretamente, uma norma[...] (Ibid., p. 181).

Além do modo, assegura que o emprego dos tempos verbais também permite agir sobre o auditório e que cada língua oferece possibilidades que mereceriam um estudo minucioso, específico. Fazendo referência à língua francesa, o autor belga afirma que o perfeito é irrefragável, o fato; o imperfeito é o tempo do transitório; o presente expressa o universal, a lei, o normal, é o tempo da máxima, "[...] daquilo que é considerado sempre atual, jamais invalidado[...]", é o que tem a propriedade de proporcionar o sentimento de presença (Ibid., p. 181).

Perelman (2005, p. 183) também analisa o uso argumentativo dos pronomes. Assevera que o emprego da terceira pessoa como sujeito, mesmo definida, no lugar da primeira, pode ter o efeito de diminuir a responsabilidade do sujeito, criar uma distância entre quem fala e o que ele diz. Em alguns casos, a utilização do pronome ou do adjetivo indefinido pode ser ambígua, podendo abranger o orador ou não. Cita como exemplo as asserções "certas pessoas estão a par de tudo" e "a gente não se diverte aqui“.

Com relação ao plural, o autor afirma que o simples fato de pôr um acontecimento no plural é significativo, pois o plural promove uma generalização e que o uso do artigo definido, assim como o do singular pelo plural, "[...] terá amiúde efeitos argumentativos dignos de nota", o mesmo ocorrendo no processo inverso (lbid., p.184): 
Em química, experimenta-se em corpos particulares e tiram-se daí afirmações concernentes a 'o cloro', 'o fósforo'; o artigo definido permite tratar as amostras como representantes de uma espécie. Assim também o uso do singular pelo plural, 'o judeu', 'o russo', tem um significado inegável. Julgamos reconhecer aí, a um só tempo, uma ação de presença, pela transformação do grupo em uma pessoa, e a unificação do ponto de vista, a impossibilidade de distinguir entre os bons e os maus que tal transformação acarreta (lbid., p. 184).

Logo a seguir, considera que o emprego inusitado do demonstrativo possibilita criar um efeito de presença muito vivo. Para exemplificar, utiliza um período de François Mauriac, em Le mystère Frontenac: "Seus olhos fixaram a grande cama com colunas torsas onde, oito anos atrás, seu irmão mais velho, Michel Frontenac, havia sofrido aquela interminável agonia” (Ibid., p. 184). Nesse caso, segundo o autor, o demonstrativo refere-se a algo que só é conhecido por uma das personagens, mas que torna o efeito de presença inegável.

Outra estratégia argumentativa analisada é aquela evidenciada por meio da escolha das qualificações, do adjetivo com vistas à argumentação. $O$ autor assegura que a escolha de um epíteto enuncia fatos incontestáveis, não sendo necessária uma justificação, pois "atribuir uma qualidade a um objeto já é escolhêla entre muitas outras[...]" (PERELMAN; OLBRECHTS- TYTECA, 2005, p. 175). Esclarece que é facilmente detectável o aspecto tendencioso de sua apresentação e que, como não é possível qualificar sem escolher, tal escolha raramente é desprovida de intenção argumentativa tanto para qualificar como para desqualificar como, por exemplo, "em vez de separar os indivíduos em pobres e ricos, basta pôr no primeiro plano a oposição entre negros e brancos, para que o branco pobre se sinta valorizado" (Ibid., p.144). Complementa que para operar essa mudança de ponto de vista, não só o adjetivo mas também o substantivo comum e o próprio podem ser utilizados. 
O autor afirma que a qualificação, a inserção numa classe, pode exprimir-se não pelo emprego de uma noção elaborada, mas pelo uso de uma conjunção de coordenação, como "e", "ou", "nem". Esse processo de qualificação por coordenação pode aplicar-se a qualquer objeto, basta tratá-los da mesma maneira (lbid., p. 146).

Sobre o advérbio, o autor o considera empregado junto ao verbo:

Estas considerações relativas ao epíteto e à inserção de um ser numa classe valem, mutatis mutandis, para os advérbios e os verbos, que, tanto uns como os outros, permitem escolher certos aspectos dos dados para pô-los em evidência. A escolha expressa pelo advérbio será mais visível do que a expressa pelo verbo. Em vez de "avançar penosamente", empregar-se-ão em geral, com muito mais eficácia, os verbos "rastejar", "esgueirar-se" (Ibid., p. 591).

Essas observações lembram-nos do importante trabalho de Van Dijk ${ }^{6}$ sobre as questões relativas a discurso e ideologia. $\mathrm{O}$ autor faz uma análise do poder da argumentação nos discursos dos meios de comunicação de massa, na transmissão da ideologia, avaliando as escolhas lingüísticas neles presentes. Para ele, essas escolhas evidenciam uma postura ideológica de segregação social com o objetivo de criar um modelo mental por meio de estratégias discursivas. ${ }^{7}$ Essa referência remete-nos, mais uma vez, ao texto de Mosca (2004b) sobre a extensão dos campos da Nova Retórica, seu intercâmbio com outras disciplinas das Ciências da Linguagem e a importância dos estudos das técnicas argumentativas desenvolvidas por Perelman.

\footnotetext{
${ }^{6}$ Van Dijk é representante da Análise Crítica do Discurso - ACD - ciência que tem interesse especial pela linguagem, pelo fato de ela mediar a ideologia. A ACD objetiva a produção de emancipação (C.f. VAN DIJK, Teun A. Cognição discurso e interação. $6^{\mathrm{a}}$ ed. São Paulo: Contexto, 2004).

${ }^{7}$ Citamos como exemplo o fato de que, após analisar vários jornais europeus de grande circulação social, o autor concluiu que existe uma polarização na utilização dos pronomes pessoais Nós e Eles: Nós refere-se a uma apresentação positiva de si mesmo - elite branca; Eles refere-se a aspectos negativos do outro - imigrantes, negros.
} 
Fica evidente que a escolha dos elementos lexicais e dos recursos lingüísticos só se torna argumentativa, por estar carregada de intenções persuasivas por parte do interlocutor, ilustrando que não é tão simples a utilização de um pronome, de um artigo, de um adjetivo ou de um tempo verbal, no lugar de outro. São as marcas lingüísticas que registram e dão força a essa argumentatividade. Perelman (2005) considera que os termos utilizados, seu sentido, sua definição, só são compreendidos no contexto fornecido pelos hábitos, pelos modos de pensar, pelos métodos, pelas circunstâncias exteriores e pelas tradições conhecidas por seus usuários. Sustenta que a adesão a certos usos lingüísticos é normalmente a expressão de tomadas de posição, explícitas ou implícitas. Fortalecidos por essas colocações, encontramos respaldo e embasamento teórico para, além de verificar os tipos de argumentos encontrados, nos artigos de opinião analisados, fazer também um levantamento das escolhas lexicais e dos recursos lingüísticos empregados como estratégia argumentativa pelo produtor do texto.

Nilce Sant'anna Martins (2003), em Introdução à Estilística, faz uma interessante abordagem sobre a questão da escolha, não como estratégia argumentativa, mas como estratégia estilística. Essa colocação pode ser útil aos nossos estudos por ampliar as possibilidades de analisar a intencionalidade ${ }^{8}$ do

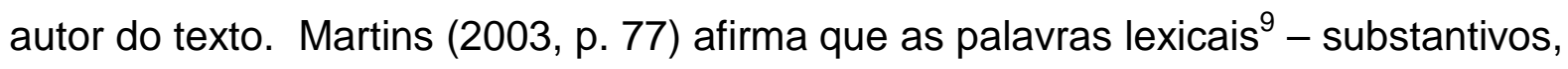
adjetivos, advérbios derivados de adjetivos e verbos que exprimem ação e processo, com exceção dos verbos auxiliares e de ligação -, "[...] despertam, em

\footnotetext{
${ }^{8}$ Como analisar a intencionalidade argumentativa dos autores dos textos que compõem nosso corpus, considerando que são crianças com idade entre dez e onze anos? Buscamos apoio em Mosca (2004a, p. 132) que afirma que a argumentatividade pode ser intuitiva e, em Louzada (1996), que afirma que faz parte das condutas lingǘsticas das crianças, desde tenra idade, a defesa de um certo ponto de vista visando ao convencimento.

${ }^{9}$ Além das palavras lexicais, a autora analisa as palavras gramaticais, cuja significação só é apreendida no contexto lingüístico e só são significativas quando acompanhadas de outras (Cf. MARTINS, N. S., 2003, p. 72).
} 
nossa mente, uma representação, seja de seres, seja de ações, seja de qualidades de seres ou modos de ações" e que "[...] remetem a algo que está fora da língua e que faz parte do mundo físico, psíquico ou social”. Os vocábulos lexicais exprimem emoções, sentimentos, julgamentos e avaliação. Com relação a este último, cita, como exemplo, a palavra palácio. A esta palavra aderem-se, além da idéia de "moradia", "edifício", a idéia de "grandeza", "luxo", "riqueza" e outras de conotações que acionam o imaginário das pessoas, em função de seu repertório discursivo.

Os recursos discursivos, como vimos, são utilizados para obter a adesão dos espíritos, é a técnica [techne] que utiliza a linguagem para persuadir e para convencer. Quando não há acordo, quando as provas são discutidas, o recurso à argumentação não pode ser evitado. Sua eficácia implica cultivo, aplicação, estratégia e habilidade na escolha dos meios para executá-la, atendendo à elocutio [recursos de expressão], à inventio [temática], ao dispositio [arranjo das partes] e também à actio [ação, considerando o outro], além da memória [posse do discurso, permite retenção e improvisação] (MOSCA, 2004b, p. 20).

Nesse jogo argumentativo, em que o outro é fundamental - pois, quando se trata de argumentar, tem-se o objetivo de levar o outro à adesão a nosso ponto de vista - conveniente faz-se, também, conceituar "auditório universal" e "auditório particular". Considerar aqueles a quem se destina o discurso é o primeiro passo para escolher as técnicas discursivas "[...] que permitem 'provocar ou aumentar a adesão dos espíritos que se lhes apresentam ao assentimento"' (PERELMAN; OLBRECHTS- TYTECA, 2005, p. 4).

Perelman (2005) esclarece que o que conservou da retórica tradicional, em suas teorias, é a idéia de auditório, imediatamente evocada, assim que se pensa em discurso que, para ele, é uma apresentação pela palavra ou pela escrita. É a esse 
auditório que o orador $^{10}$ é obrigado a adaptar-se, pois é em função dele que qualquer argumentação se desenvolve. Com efeito, o que é admitido por certas pessoas não o é necessariamente por outras, daí a importância de se considerar o pathos. Portanto, para ele, auditório é o conjunto daqueles que o orador quer influenciar com sua argumentação.

Cada orador pensa naqueles a quem procura persuadir e que constituem o auditório ao qual se dirige seu discurso. Essa concepção deve ser tão próxima quanto possível da realidade, pois uma imagem inadequada fará com que a intenção persuasiva do discurso não se efetive. "Auditório universal” é um auditório ideal, construção mental de quem se refere a ele, é constituído, segundo o autor, pela humanidade inteira, ou pelo menos [virtualmente] por todos os homens adultos e normais. Outro tipo de auditório é formado, no diálogo, unicamente pelo interlocutor a quem se dirige, é o "auditório particular". O terceiro é constituído pelo próprio sujeito quando ele delibera consigo mesmo as razões de seus atos (Ibid., p. 33-34).

Um artigo de opinião é impresso em jornais e revistas de circulação social, seu auditório é composto por leitores representantes das mais variadas classes e atividades sociais, adultos, racionais e normais, representantes da humanidade inteira, o que, para o autor das teorias argumentativas, faz com que esse auditório seja classificado como universal, logo a argumentação deve ser convincente, baseada em um raciocínio lógico e apresentar provas objetivas, apelando para o racional.

\footnotetext{
${ }^{10}$ Perelman (2005), ao tratar de questões relativas às técnicas retórico-argumentativas, utiliza o termo orador para referir-se ao produtor do discurso oral ou escrito. Achamos por bem manter esse vocábulo, ao logo de nossos estudos, pois referenciam esse autor que se inspirou em Aristóteles e seus gêneros oratórios para construir seu tratado. Contudo, empregaremos também, como sinônimos, as palavras produtor do texto, enunciador, escritor e autor pelo fato de nosso corpus ser composto por textos escritos.
} 
Uma argumentação dirigida a um auditório universal deve convencer o leitor do caráter coercivo das razões fornecidas, de sua evidência, de sua validade intemporal e absoluta, independente das contingências locais ou históricas (Ibid., p. 35).

Em contrapartida, pelo próprio formato desse veículo de comunicação, esse leitor recebe a mensagem de forma individualizada, caracterizando esse auditório como particular, cuja persuasão exige uma argumentação que leve em conta razões afetivas e emocionais.

Concluímos, portanto, que, com relação ao artigo de opinião, a necessidade de se pensar no leitor é fundamental, pelo fato de se desejar a comunhão dos espíritos, a adesão aos valores defendidos. Para tanto, devem-se utilizar argumentos múltiplos para conquistar os diversos componentes desse auditório presumido. Nas palavras de Perelman (2005, p. 24), "é a arte de levar em conta, na argumentação, esse auditório heterogêneo que caracteriza o grande orador".

Importante também para a conquista desse auditório é a figura do orador, este se constrói, segundo ele, conforme o auditório a quem se dirige, além do que, é preciso ter uma qualidade reconhecida para tomar a palavra e ser ouvido. Afirma que essa qualidade, sem a qual muitas vezes nem se é autorizado a tomar a palavra, pode variar conforme as circunstâncias e que há certos campos em que essa habilitação é minuciosamente regulamentada.

Sobre essa questão, em Retóricas, o autor afirma que, embora o caráter do auditório seja primordial na argumentação retórica, a opinião que esse auditório tem do orador desempenha papel determinante ${ }^{11}$. Ainda que o prestígio do orador possa

\footnotetext{
11 Galit Haddad, em seu artigo Ethos prévio e ethos discursivo: o exemplo de Romain Rolland, afirma que "o ethos prévio ou pré-discursivo condiciona a construção do ethos discursivo" e que "o orador, ao pronunciar seu discurso, deve construir uma imagem de si que seja análoga a seu objetivo argumentativo, levando em consideração a idéia que presumivelmente o auditório projeta dele” ( In: AMOSSY, Ruth, 2005).
} 
resultar do discurso, uma parte desse prestígio está, a cada enunciado, exposta ao risco, pois da mesma forma "[...] como a personalidade do orador garante a seriedade da argumentação, inversamente, uma argumentação fraca ou desastrada diminui a autoridade do orador" (PERELMAN, 2004, p. 74-75).

Em Retóricas, Perelman (2004, p. 68), assinala que o discurso epidítico tem por efeito colocar em destaque quem o pronuncia: "o orador é o ponto de mira". Para pronunciá-lo o orador deverá ter garantido previamente seu prestígio, devido à sua pessoa ou à sua função.

A força persuasiva dos argumentos utilizados pelo produtor do artigo de opinião começaria, pois, a ser construída pelo seu prestígio, pelo respeito que os leitores devotam a ele, por meio do conhecimento de seu ethos pré-discursivo. Trata-se do argumento de autoridade referente ao orador: "[...] existe uma série de argumentos cujo alcance é totalmente condicionado pelo prestígio. A palavra de honra, dada por alguém como única prova de uma asserção, dependerá da opinião que se tem dessa pessoa como homem de honra [...]" (PERELMAN; OLBRECHTSTYTECA, 2005, p. 347).

Considerando essas afirmações, em relação aos artigos de opinião que compõem nosso corpus, a princípio, temos um produtor de texto que não é um jornalista e que também não é uma pessoa reconhecida socialmente. Neste cenário $^{12}$, temos um aluno que representa o papel de articulista e um leitor que deve entrar nesse jogo cênico ${ }^{13}$, proposto pelas oficinas ${ }^{14}$ e criado pelo professor

\footnotetext{
${ }^{12}$ Empregamos o termo cenário na mesma acepção de Marcuschi (2005). O autor, ao utilizar esse termo, faz a seguinte citação: "O termo cenário aparece na acepção de Herbert H. Clark (1996, p. 3-12) quando analisa os tipos de cenário em interações verbais orais e escritas [...]". Os cenários surgem na combinação de cena e meio para constituírem a arena comunicativa (Cf. MARCUSCHI, L. A. O diálogo no contexto da aula expositiva: continuidade, ruptura e integração. In: PRETI, Dino (Org). Diálogos na fala e na escrita. São Paulo: Humanitas.VOL.7, 2005, p. 45).

${ }^{13}$ Segundo Koch (2004a, p. 22), Carlos Vogt desenvolve a concepção de linguagem como ação dramática: representação 1: todo enunciado diz algo, representa um estado de coisas do mundo; representação 2: mas o diz de um certo modo, isto é, o modo como o enunciado é dito é demonstrado [modalizado] por meio de marcas
} 
com finalidade didática. A Oficina 1, descrita por nós em capítulo posterior, sugere ao professor a criação de uma situação de produção. A sala de aula tornar-se-á, por meio de um jogo de faz-de-conta, uma verdadeira redação de jornal, tendo o professor como editor e o aluno como articulista convidado. O prestígio de seu ethos pré-discursivo, neste caso, já existiria e seu prestígio como orador será construído como o de qualquer outro, pela maneira como conduz seus argumentos e busca promover a adesão de seu interlocutor.

Cabe ao produtor do artigo, ao longo de sua argumentação, manter ou aumentar esse prestígio. Com o objetivo de provocar a adesão, o acordo com seu auditório, ele utilizará premissas que servirão de fundamento para sua construção. Os objetos de acordo que podem servir de premissas são agrupados em duas categorias, uma relativa ao real - os fatos, as verdades e as presunções; e outra relativa ao preferível - os valores, as hierarquias e os lugares do preferível.

Com respeito às premissas relativas ao real, Perelman (2005, p. 75$)$ define fato como sendo aquilo "[...] que é comum a vários entes pensantes e poderia ser comum a todos"15 , com a característica de podermos "[...] postular a seu respeito um acordo universal, não controverso". Para as verdades, o autor aplica a mesma definição de fatos, apesar dos problemas filosóficos das relações entre eles. As presunções estão vinculadas ao normal e ao verossímil e como os fatos e as verdades também gozam do acordo universal como, por exemplo, "[...] a presunção de que a qualidade de um ato manifesta a da pessoa[...]" (Ibid. p.79).

\footnotetext{
lingüísticas. Esse autor utiliza-se de uma acepção teatral para designar os diferentes papéis distribuídos nas cenas dramáticas que são os atos de fala, entendidos por nós como qualquer ato interativo comunicacional que utiliza a linguagem verbal oral ou escrita. É criado um jogo cênico pelo qual se distribuem, entre os personagens, máscaras que só têm realidade dentro do próprio discurso, determinando um jogo de representações dramáticas, ou seja, um mascaramento recíproco que é parte constitutiva essencial do jogo argumentativo.

${ }^{14} \mathrm{O}$ material encontra-se em anexo.

${ }^{15}$ Perelman esclarece que retirou essa citação de H. Poincaré, La valeur de la science, 1946, Introdução, p. 65.
} 
Outras questões de relevância no processo argumentativo, além dos fatos, das verdades e das presunções, são os valores, as hierarquias e os lugares do preferível. Valores são objetos de acordo a que se recorre para motivar o ouvinte a fazer certas escolhas, em vez de outras. Existem valores que são universais ou absolutos tais como o Bem, o Verdadeiro, o Belo entre outros, e os valores particulares que podem ser vinculados aos universais e servir para especificá-los. O autor considera fundamental a distinção entre valores abstratos, como a justiça ou a veracidade, e valores concretos, como a Igreja ou a França. Afirma que, sejam quais forem os valores dominantes num meio cultural, a argumentação se baseia, conforme as circunstâncias, ora nos valores abstratos ora nos valores concretos. Importante também é a hierarquização desses valores como, por exemplo, a superioridade dos homens sobre os animais, dos deuses sobre os homens etc (Cf. PERELMAN; OLBRECHTS - TYTECA, 2005, p. 83-96).

Para fundamentar valores ou hierarquias ou reforçar a intensidade da adesão, pode-se relacioná-los com outros valores ou com outras hierarquias. É ainda possível recorrer a premissas de ordem geral: os lugares. Primeiramente, Perelman analisa os lugares de quantidade, ou seja, premissas que afirmam que alguma coisa é melhor do que outra por razões quantitativas. Esclarece que, entre os vários lugares de quantidade assinalados por Aristóteles, temos: um maior número de coisas é preferível a um menor número; o que é mais duradouro é preferível ao que é menos. Em segundo lugar, temos a análise dos lugares de qualidade que remete à valorização do único, algo de valor incomparável e aparece quando se contesta a virtude do número: o verdadeiro não pode sucumbir, seja qual for o número de seus adversários. Por último temos outros lugares como: a) os da ordem que afirmam a superioridade do anterior sobre o posterior; b) os do existente 
que afirmam a superioridade do que existe, do que é atual, do que é real sobre o possível, o eventual ou o impossível; c) os da essência que concedem a superioridade aos indivíduos enquanto representantes bem caracterizados dessa essência; d) os do valor da pessoa vinculados à sua dignidade, ao seu mérito, à sua autonomia (lbid., p. 94-112).

O autor adverte que foram mencionados os lugares utilizados com mais freqüência. Rocco (1989) assegura que a escolha de qualquer um deles deverá ser feita em função de certas visões de mundo, de padrões eleitos, de uma determinada ideologia, de um tempo histórico. "Assim, por exemplo, as relações velho/ novo; durável/ momentâneo; rico/ pobre, entre outras, serão caracterizadas e valorizadas diversamente, como aliás já o foram em períodos anteriores da história" (ROCCO, 1989, p. 59).

Outro aspecto não menos importante é a oposição existente dentro dos próprios auditórios, uns especializados e outros marcados pelo senso comum. Para o autor, "[...] senso comum consiste numa série de crenças admitidas no seio de uma determinada sociedade, que seus membros presumem ser partilhadas por todo ser racional". Acrescenta que o orador deve contar, para suas presunções, com a inércia psíquica e social do ouvinte, que corresponde à inércia na física, presumir que seja em virtude da força do hábito, a atitude admitida ou adotada anteriormente - o normal, o real, o atual - continuará no futuro, isso é, não precisa ser justificada. No entanto, quando se trata de mudanças, elas precisam ser justificadas e é preciso encontrar razões para isso (PERELMAN; OLBRECHTSTYTECA, 2005, p. 112).

Quanto às possibilidades argumentativas, o autor traz três tipos de argumentação: ad humanitatem ou ad rem, baseada na verdade, é válida para toda 
humanidade, visa ao auditório universal; ad hominem, baseada na opinião, é válida para persuadir certas pessoas, visa ao auditório particular e ad personam que se constitui em um ataque contra a pessoa do adversário, visa a desqualificar o outro.

O autor destaca, na seqüência de seu tratado, a função das figuras: tropos. Elas passam a ser examinadas como figuras do discurso, por participarem de um procedimento discursivo de construção de sentido. Considerando-as segundo o fim a que se destinam na argumentação, classifica-as como figuras de presença, figuras de seleção e figuras de comunhão [grifo do autor].

As figuras de escolha ou de seleção, representadas pela metáfora, perífrase, retificação, correção, definição, sinédoque e metonímia, impõem ou sugerem uma escolha. Dotadas de grande força persuasiva, resultam em grande efeito argumentativo.

As figuras de comunhão, artifício utilizado para criar a comunhão com o auditório, são representadas, pelo uso de clichês, provérbios e máximas. Isso porque o estereótipo ${ }^{16}$, no caso do clichê, como uma representação coletiva cristalizada é um meio fácil de comunhão; as máximas condensam a sabedoria das nações e são meios eficazes de promover essa sabedoria e fazê-la evoluir, sua força é tão grande, que são necessárias sérias razões para rejeitá-la. Os provérbios são máximas curtas, tornadas populares, por exprimir um acontecimento particular, sugerem uma norma e apresentam um aspecto menos erudito e mais popular que certas máximas. É o lugar comum - a doxa para Aristóteles - compartilhado por todos, aceito pela coletividade e utilizado como estratégia argumentativa. Podemos acrescentar a essas figuras a emoção que atua sobre a imaginação, a interrogação oratória, a citação, a enálage de pessoa, a alusão, a pressuposição e a apóstrofe.

\footnotetext{
${ }^{16}$ Cf. Charaudeau, P.; MAINGUEnEAU, D.Dicionário de Análise do Discurso, 2004, p. 215.
} 
Considerar que para cada auditório existe um conjunto de coisas admitidas que têm a possibilidade de influenciar suas reações, é considerar os acordos de que dispõe o orador, nos quais pode apoiar-se e que servirão de ponto de partida para a sua argumentação. Esses acordos constituem um dado que precisa ser selecionado e o simples fato de selecionar certos elementos e apresentá-los ao auditório, confere a esses elementos uma presença que, como vimos, é para o autor "um fator essencial da argumentação", pois ela "[...] atua de um modo direto sobre nossa sensibilidade" (PERELMAN; OLBRECHTS- TYTECA, 2005, p. 132). Lançar mão da repetição, especificar o lugar e o momento de uma ação, utilizar termos concretos em vez dos abstratos, deixa mais viva a imagem que evocam, aumentando a impressão de presença. As figuras de presença, que têm por objetivo presentificar o objeto do discurso, são: onomatopéia, sinonímia, amplificação, enálage de tempo e repetição.

Em seguida, o autor dá início à classificação dos argumentos em dois grupos: os argumentos quase-lógicos e os argumentos baseados na estrutura do real. Quanto aos primeiros, afirma que se apresentam como comparáveis a raciocínios formais, lógicos ou matemáticos, têm pretensão a certa validade em virtude de seu aspecto racional. No entanto, possuem somente uma aparência demonstrativa pelo seu caráter não-formal. Subdivide-os em argumentos que apelam para estruturas lógicas - contradição, identidade, transitividade, analiticidade, regra de justiça e reciprocidade - e os que apelam para as relações matemáticas - inclusão da parte no todo, divisão do todo em partes, comparação, argumento pelo sacrifício e probabilidade.

Inicia a análise dos argumentos quase-lógicos que apelam para estruturas lógicas destacando a identidade e a definição na argumentação que, para o autor 
das teorias, só serão consideradas quase-lógicas quando a identificação de seres, de acontecimentos ou de conceitos der azo a uma justificação argumentativa. Essa identificação consiste no uso de definições que podem ser justificadas com a ajuda de argumentos ou serem, elas próprias, argumentos. Outro argumento quase-lógico é a analiticidade. Toda análise é direcional e a escolha de uma direção é determinada pela busca de adesão do interlocutor, podendo-se utilizar definições ou enumerações. Caso a análise não nos ensine nada de novo, será caracterizada como tautologia. Em alguns casos, esta parece evidente e voluntária, criando uma identidade ou uma contradição como, por exemplo, "tostão é um tostão" e "Entramos e não entramos no mesmo rio", máxima de Heráclito citada por Perelman (lbid., p. 238 - 247).

Temos também a regra de justiça que "[...] requer a aplicação de um tratamento idêntico a seres ou a situações que são integrados numa mesma categoria" (Ibid., p. 248). Ela possibilitará que o fundamento utilizado em casos anteriores seja apresentado sob forma de argumentação para casos futuros. Os argumentos de reciprocidade "[...] visam a aplicar o mesmo tratamento a duas situações correspondentes”. Nesse caso, para que seja aplicável a regra de justiça, a mesma relação deve ser afirmada tanto entre $a$ e $b$ como entre $b$ e $a$, ou seja, uma relação simétrica. Citemos Quintiliano apud Perelman: "o que é honroso aprender, também é honroso ensinar" ou preceitos de moral humanista como o enunciado judaico-cristão: "Não faças a outrem o que não gostarias que te fizessem"(Ibid., p. 252). Perelman cita, também, os argumentos de reciprocidade apresentados como o inverso um do outro, como na afirmação de Pascal: "Pouca coisa nos consola, porque pouca coisa nos aflige" (PERELMAN; OLBRECHTSTYTECA, 2005, p. 254 et seq.). 
Sobre os argumentos de transitividade, Perelman (2005) assegura que a transitividade é uma propriedade formal de certas relações que "[...] permite passar da afirmação de que existe a mesma relação entre os termos $a$ e $b$ e entre os termos $b$ e $c$, à conclusão de que ela existe entre os termos a e $c[\ldots]$ ". Considera transitivas as relações de igualdade, de inclusão e de ascendência. Afirma serem inestimáveis, nos casos em que se trata de ordenar seres ou acontecimentos, cuja confrontação direta não pode ser efetuada.

Passando para os argumentos quase-lógicos que apelam para as estruturas matemáticas temos a inclusão da parte no todo. O autor observa a necessidade de distinguir dois tipos de procedimento: o que se limita a demonstrar a inclusão das partes num todo; e o que demonstra a divisão do todo em suas partes. Os primeiros não atribuem nenhuma qualidade particular nem a certas partes nem ao conjunto: "o que vale para o todo vale para a parte[...] ". "O mais das vezes a relação do todo com suas partes é tratada pelo ângulo quantitativo: o todo engloba a parte e [...] o valor dela é proporcional à fração que ela constitui com relação ao todo" (Ibid., p. 262). Quanto aos segundos, os argumentos por divisão, "[...] implicam evidentemente, entre as partes, certas relações que fazem que a soma delas seja capaz de reconstituir o conjunto" (Ibid., p. 271). Esclarece que o argumento por divisão está na base do dilema e também na relação de complementaridade.

Sobre os argumentos de comparação, Perelman (2005) afirma que, sem eles, a argumentação não poderia ir muito longe. Neles, os objetos são avaliados uns em relação aos outros e esses argumentos são, em geral, apresentados como constatação de fato. Assegura que a escolha dos termos de comparação adaptados ao auditório pode ser um elemento essencial da eficácia de um argumento e que a utilização do superlativo é eficaz na argumentação, pois indica superioridade de 
algum objeto, seja por ser superior a todos os outros, seja por ser incomparável, único em seu gênero. Lembra que "para desqualificar alguém, um procedimento eficaz é cotejá-lo com o que ele despreza [...]". A verdade é que os seres comparados fazem, a partir daí, parte de um mesmo grupo" (lbid., p. 277).

Já a argumentação pelo sacrifício, segundo o autor, é a que alega o sacrifício a que se está disposto a sujeitar-se, para obter certo resultado, permite medir o valor atribuído ao motivo do próprio sacrifício. Como ilustração, cita Pascal: "Só creio nas histórias cujas testemunhas se deixariam degolar" (Ibid., p. 288).

Com respeito à argumentação quase-lógica pelo provável, esta ganha importância, se houver avaliações baseadas na relevância dos acontecimentos e na probabilidade de seu aparecimento. Em geral, assume um caráter empírico.

O estudioso faz, também, algumas considerações sobre o papel do ridículo na argumentação. Ridículo é aquilo que merece ser sancionado pelo riso; é uma forma de condenar um comportamento transgressor que não se julga bastante grave ou perigoso, a ponto de ter de ser reprimido com violência. O ridículo é uma arma poderosa de que o orador dispõe contra os que pretendem abalar sua argumentação.

Após tecer considerações sobre os argumentos do primeiro grupo, os quaselógicos, o autor trata dos argumentos do segundo grupo: os argumentos baseados no real. Esclarece que estes são "[...] fundamentados na estrutura do real [...]" e "[...] valem-se dela para estabelecer uma solidariedade entre juízos admitidos e outros que se procura promover" (PERELMAN; OLBRECHTS- TYTECA, 2005, p. 297). Examina os argumentos baseados na estrutura do real, segundo as ligações que unem um fenômeno a suas conseqüências - ligações de sucessão: vínculo causal, argumento pragmático, causa e conseqüência, fins e meios, argumento do 
desperdício, argumento de direção - e as ligações que unem uma pessoa a seus atos, um grupo a seus indivíduos - ligações de coexistência: interação entre o ato e a pessoa, argumento de autoridade, ligação simbólica, argumento de hierarquia, técnica de ruptura.

Dentre as ligações de sucessão, o primeiro caso tratado é o vínculo causal e seus efeitos argumentativos. Ele ocorre quando se deseja, a partir de um dado acontecimento, aumentar ou diminuir a crença na existência de uma causa que o explicaria ou de um efeito que dele resultaria. Já o argumento pragmático é aquele que permite apreciar um ato ou um acontecimento, consoante suas conseqüências favoráveis ou desfavoráveis, presentes e futuras e não requer, para ser aceito pelo senso comum, nenhuma justificação.

Com relação aos argumentos que consideram os fins e os meios, Perelman (2005, p. 315) afirma que existe uma interação entre os objetivos perseguidos e os meios empregados para atingi-los e que não devemos esquecer que, "[...] conquanto seja verdade que o fim valoriza os meios, nem sempre ele os justifica, pois o uso destes pode ser condenável em si ou ter conseqüências desastrosas[...]". Para que o meio seja valorizado pelo fim, é necessário que ele seja eficaz.

O argumento do desperdício prega que, uma vez que já se começou algo e já se aceitaram sacrifícios, cumpre prosseguir, pois tudo o que já se fez, se perderia em caso de desistência. Poderiam aproximar-se deste argumento todos os que alegam a oportunidade que não se deve perder, um meio que existe e do qual é preciso servir-se.

O argumento de direção responde à pergunta: aonde se quer chegar? Pode ser utilizado cada vez que uma meta for considerada como um ponto de referência, uma etapa numa certa direção. Ele visa sempre a tornar uma etapa solidária de 
desenvolvimentos posteriores, ele "[...] desperta o temor de que uma ação nos envolva num encadeamento de situações cujo desfecho se receia[...]" (Ibid., p. 327). Pode assumir diversas formas como: a) propagação: alerta contra o crescimento nocivo de certos fenômenos; b) argumento do contágio: considera o fenômeno inicial como um mal; c) argumento da vulgarização: alerta contra a desvalorização do que é raro; d) argumento da consolidação: alerta contra repetições que dão pleno significado ao que era apenas esboço; e) mudança de natureza: enfatiza a mudança entre as primeiras etapas e a conclusão.

Ao contrário do anterior, os argumentos de superação insistem na possibilidade de ir sempre mais adiante num certo sentido, sem que se entreveja um limite nessa direção, com um crescimento contínuo de valor. Para realizar a superação, o autor considera duas figuras: as lítotes e a hipérbole. A primeira enfraquece o pensamento e a segunda o exprime de forma exagerada.

Nas ligações de coexistência, temos a união de duas realidades de nível desigual, sendo uma mais explicativa do que a outra. O primeiro caso é o da pessoa e seus atos. Baseia-se no seguinte: a construção da pessoa humana, vinculada aos atos, é ligada a uma distinção entre o que considera importante, próprio do ser de quem se fala e o que considera transitório, manifestação exterior do sujeito. Afirma que "a reação do ato sobre o agente é capaz de modificar constantemente a nossa concepção de pessoa, em se tratando de atos novos que lhe atribuímos ou de atos antigos aos quais nos referimos" e que a pessoa coincidiria com um conjunto estruturado de seus atos comuns (Ibid., p. 337). Explica que ato é tudo que pode ser considerado emanação da pessoa, como ações, modos de expressão, reações emotivas, cacoetes involuntários ou juízos. 
Perelman considera um ato um elemento que permite construir e reconstruir nossa imagem da pessoa. Atos passados e seu efeito adquirem certa consistência. Esclarece que o comportamento e o modo de ser dos homens podem ser explicados não só pelo fato de eles pertencerem a um grupo, como também pela época ou regime com que se relacionam. Completa, afirmando que podemos utilizar essa ligação entre ato e pessoa para desqualificar o adversário e que, quando desejamos impedir a reação do ato sobre o agente ou a reação do agente sobre o ato, podemos utilizar a técnica de ruptura que consiste em romper essa relação. Essa técnica também é bem-vinda quando queremos romper a ligação entre o grupo e seus membros, o que pode ser realizado por meio da exclusão.

Ainda com relação à interação entre ato e pessoa, indica que merece atenção especial o discurso como ato do orador, pois ele é a manifestação por excelência da pessoa, é a impressão que se dá de si mesmo por meio das próprias palavras, fato que os antigos chamavam de ethos oratório [grifo do autor]. Essa interação expõe constantemente o prestígio de quem argumenta.

Continuando o estudo das estratégias argumentativas, Perelman (2005) avalia a influência que o prestígio exerce sobre os argumentos, como no caso do argumento de autoridade. Ele ocorre quando se mencionam atos ou juízos de uma pessoa ou de um grupo de pessoas como meio de prova a favor de uma tese, podendo constituir a única prova ou ser completado por outros recursos de argumentação. Assevera que, antes de invocar uma autoridade, costuma-se confirmá-la, consolidá-la, dar-lhe a seriedade de um testemunho válido, para que sua autoridade seja reconhecida pelo auditório. As autoridades invocadas são variáveis, podem ser a "opinião comum"17, o parecer de certas categorias de

\footnotetext{
${ }^{17}$ As aspas, nesta expressão como nas seguintes, que aparecem neste parágrafo, foram utilizadas pelo autor.
} 
homens - filósofos, cientistas etc - pessoas designadas pelo nome e até mesmo será impessoal como "a Bíblia”, “ a doutrina” ou "a física”. Como no argumento anterior, pode-se utilizar o argumento de autoridade para desqualificar o outro, denunciando a incompetência do até então considerado competente.

Outro tipo de argumento tratado pelo autor é o da ligação simbólica que acarreta transferências entre o símbolo e o simbolizado. É o que ocorre quando, por exemplo, a cruz, a espada, a bandeira são encarados como símbolos do cristianismo, da pátria. Pelo fato de ser mais concreto, mais manipulável que o simbolizado, o símbolo impõe sua presença e desperta sentimentos de amor ou ódio, veneração ou desprezo. Não se vê a pátria, mas vê-se ou descreve-se a bandeira tremulando ou desfraldando-se ao vento. Esse recurso desempenha papel eminente na apresentação de premissas à argumentação e pode ser realizado tanto pela metonímia quanto pela sinédoque.

Os argumentos de hierarquia dupla, assim como os valores, fazem parte dos acordos que servem de premissas ao discurso. Exprimem normalmente uma idéia de proporcionalidade, direta ou inversa, ou pelo menos um vínculo entre termo e termo. Ele permite assentar uma hierarquia contestada numa hierarquia admitida e, por isso, presta enorme serviço quando se trata de justificar regras de conduta. Se certas leis são preferíveis a outras, é a elas que cumpre obedecer, não às outras. Se certas virtudes são superiores, cumpre esforçar-se por adquiri-las.

Ao tratar das ligações que fundamentam a estrutura do real, temos o fundamento pelo caso particular - o exemplo, a ilustração, o modelo e o antimodelo - e, pelo raciocínio por analogia - a analogia e a metáfora.

Inicialmente, o autor examina aqueles representados pelo caso particular, tratando, a princípio, do argumento pelo exemplo. Este permite uma generalização 
a partir de casos particulares. Essa generalização permite a passagem de um caso a outro, pois parte de um relato concreto que o ouvinte não tem motivo para colocar em dúvida. A escolha dos casos deverá ser feita de tal forma, que se tenha segurança do caráter representativo das amostras extraídas do real, lembrando que essa escolha compromete o orador como uma espécie de confissão.

Já o argumento por ilustração difere do argumento pelo exemplo, pelo fato de ser incumbido de fundamentar a regra. Esta tem a função de reforçar a adesão a um princípio conhecido e aceito, fornecendo casos particulares que esclarecem o enunciado geral. O autor observa que o exemplo deve ser incontestável, a ilustração pode ser duvidosa, mas deve impressionar vivamente a imaginação, para impor-se, pois ela corrobora a regra. Ressalta que a ilustração voluntariamente inadequada pode constituir uma forma de ironia. Cita Antônio, personagem da peça Júlio César de Shakespeare que, embora não cessando de repetir que Bruto é um homem honrado, enumera seus atos de ingratidão e de traição (PERELMAN E OLBRECHTS-TYTECA, 2005, p. 412).

Com relação aos argumentos pelo modelo e pelo antimodelo, o autor afirma que, quando se trata de conduta, um comportamento particular pode não só servir para fundamentar ou ilustrar uma regra geral, como para estimular uma ação nele inspirada. O valor da pessoa e seu prestígio, habitualmente, são propostos como modelo para a imitação de todos; suas características ou atos poderão inclusive ser adaptados a uma imagem ou situação que se deseja inspirar. No entanto, se o que se quer é afastar-se dessa pessoa e de seu prestígio, a ação do antimodelo é mais eficaz, a repulsa chegará, às vezes, a provocar a mudança de uma atitude anteriormente adotada, pela única razão de que é igualmente a do antimodelo. Perelman (2005, p. 419) acrescenta que, para não se correr o risco de escolher 
modelos que comportam características repreensíveis e antimodelos com qualidades dignas de imitação, "os autores são levados a embelezar ou a enegrecer a realidade, a criar heróis e monstros, totalmente bons ou totalmente maus, a transformar a história em mito, em lenda, em figura exageradamente esquemática".

Analisados os argumentos fundamentados pelo caso particular, o autor passa a tratar do argumento fundamentado no raciocínio por analogia. A analogia ocorre quando há similitude de estruturas, em que se pode aplicar a seguinte fórmula: A está para $\mathrm{B}$, assim como $\mathrm{C}$ está para D. O autor chama de tema o conjunto dos termos $\mathrm{A}$ e $\mathrm{B}$; e de foro o conjunto dos termos $\mathrm{C}$ e $\mathrm{D}$ que servem para estribar o raciocínio. E adverte: para haver analogia, tema e foro devem pertencer a áreas diferentes, pois quando as duas áreas forem iguais, temos um raciocínio pelo exemplo ou pela ilustração. O autor cita um exemplo de analogia tirada de Aristóteles: "Assim como os olhos dos morcegos são ofuscados pela luz do dia, a inteligência de nossa alma é ofuscada pelas coisas mais naturalmente evidentes" (lbid., p. 424).

$\mathrm{Na}$ seqüência de suas análises, faz considerações sobre a metáfora, afirmando que "[...] ela é um tropo, ou seja, uma mudança bem-sucedida de significação de uma palavra ou de uma locução[...]" e que, segundo Dumarsais, "[...] transporta-se, por assim dizer, a significação própria de um nome para outra significação, que só lhe convém em virtude de uma comparação que existe na mente" (Ibid., p. 453). Assegura que, no que tange à argumentação, pode ser concebida como uma analogia condensada resultante da fusão de um elemento do foro com um elemento do tema. Exemplifica, buscando, em Aristóteles, essa relação analógica: "O que a velhice é para a vida, a noite é para o dia. Logo, diremos a noite velhice do dia e a velhice noite da vida [...]". Ressalta seu valor 
argumentativo pela grande força persuasiva que possui. E completa: "toda analogia - afora aquelas que se apresentam em forma rígidas, como a alegoria, a parábola torna-se espontaneamente metáfora" (lbid., p. 453 - 457). Esclarece que é justamente a ausência de fusão na alegoria e na parábola, a base da diferença entre elas e a metáfora.

Ao longo da exposição sobre as técnicas da arte de argumentar, Perelman (2005) envereda pelas ligações argumentativas que, como afirma, tornam solidários elementos que podiam ser, de início, considerados independentes. Quando há recusa em reconhecer a existência de uma ligação, ocorre a dissociação das noções que consiste em cortar os fios que amarram elementos isolados, como na técnica da ruptura, e também em modificar a própria estrutura deles. Essa estratégia tem, como protótipo, o par aparência-realidade de uso generalizado e importância filosófica.

Ao tratar da interação dos argumentos, insiste que os argumentos estão em constante interação. É ela que determina, em grande parte, a escolha dos argumentos, sua amplitude e sua organização, tendo em vista a força dos argumentos [grifo do autor]. Esta força está vinculada tanto à intensidade de adesão do ouvinte às premissas, quanto à relevância dos argumentos em debate. Ela se manifesta, de um lado, pela dificuldade que haveria em refutar e, de outro, por suas qualidades próprias. Toda refutação merece nosso esforço e é digna de ser levada em consideração, não só com o objetivo de prestígio, mas também a fim de conquistar a atenção do auditório e assegurar força aos argumentos empregados. Estratégia importante é refutar uma objeção para deixar o campo livre para interpretações mais favoráveis.

Da mesma forma que devemos considerar a força dos argumentos para garantir a adesão do auditório, também é preciso empregar estratégias inversas 
como meio de diminuir essa força, em especial a dos adversários, por exemplo: uma emoção exagerada, desproporcional ao assunto; ou a acentuação do caráter genérico, previsto e fácil de encontrar.

Em um processo de argumentação, não há limite absoluto para acumulação útil dos argumentos, eles estão em interação constante, sendo que a convergência entre eles estimulará a amplitude da argumentação. Nos artigos analisados, em nosso corpus, nota-se, como veremos, uma acumulação e uma interação entre os argumentos. Perelman (2005, p. 524) adverte que a amplitude pode, por outro lado, ser perigosa, pois todo argumento evocado, por sua presença, chama a atenção do auditório sobre certos fatos, leva-o a pensar em situações que podem suscitar objeções. Aponta alguns paliativos para esse perigo: introduzir uma argumentação complementar para evitar os efeitos de argumentos incompatíveis; deixar alguns argumentos subentendidos, caso se tema sua utilização; fazer uma alusão ou deixar seu desenvolvimento a cargo do ouvinte por meio de reticências ou suspensão do pensamento.

Quanto à ordem dos argumentos, em um discurso argumentativo, ela deve levar em conta todos os fatores suscetíveis de favorecer a acolhida pelos ouvintes. Em outras palavras, essa ordem é objeto de uma escolha cuja única regra é a busca de adesão. Quando se dispõe de certo número de argumentos para sustentar a tese defendida, examinam-se três modos de disposição: a ordem de força decrescente; a ordem de força crescente; e a nestoriana ${ }^{18}$ que consiste em começar e terminar com os argumentos mais fortes. As duas primeiras apresentam inconvenientes, pelo fato de que uma principia por argumentos medíocres que podem indispor o ouvinte; outra pode causar uma impressão desfavorável, já que, por vezes, a primeira idéia é a que

\footnotetext{
${ }^{18}$ Perelman (2005) esclarece que Nestor havia colocado, no meio, suas tropas menos confiáveis.
} 
se conserva na mente do interlocutor. Por essa razão, é preconizada a ordem nestoriana.

Por fim, Perelman (2005) faz referência às partes do discurso. Inicia afirmando que o exórdio é a que pretende, mais especificamente, atuar sobre a disposição do auditório, tendo por objetivo captar sua benevolência, sua atenção, seu interesse, garantindo as condições prévias favoráveis para que seja apresentada a argumentação. Ele "[...] sempre será adaptado às circunstâncias do discurso, ao orador e ao auditório, ao assunto tratado, aos adversários" (Ibid., p. 562). Preparado o auditório, cumpre indicar a tese que se defenderá. Além de orientar o discurso, ela é também uma tomada de posição do orador.

Concluímos nossa síntese, asseverando a importância dos estudos realizados sobre as estratégias retórico-argumentativas como fundamentação para a leitura e análise do nosso corpus.

Devemos, ainda, fazer uma reflexão sobre a idade e o nível dos alunos cujos textos compõem o corpus. Trata-se de pré-adolescentes, ainda em formação, com uma capacidade de argumentação em progressão. Sendo assim, apenas uma parte dos procedimentos descritos será perceptível em sua produção, como ilustrarão as análises adiante. 


\subsection{Macrossintaxe do Discurso}

[...] os elementos [...] inscrevem-se no discurso através de marcas lingüísticas, fazendo com que ele se apresente como verdadeiro "retrato" de sua enunciação.

(Ingedore G. V. Koch)

Luiz Antônio Marcuschi, ao prefaciar o livro Argumentação e Linguagem de Ingedore G. V. Koch (2004a, p. 9), afirma que "a análise do discurso ou lingüística de texto [...] tem dimensões que abarcam o que há longo tempo vem florescendo e se desenvolvendo em várias áreas interligadas: a semântica, a pragmática, a retórica e a teoria da argumentação, entre outras", e que a autora constrói suas análises, percorrendo esses domínios e seus problemas, centrando-se, sobretudo, na Semântica Argumentativa, situada por ela no âmbito da Macrossintaxe do Discurso.

Koch (2004a) considera que faltam, entre a lingüística do enunciado e a lingüística da enunciação, alguns conceitos que podem ser encontrados na Semântica Argumentativa, levando em conta a língua em sua intersubjetividade. Segundo ela, esta seria a síntese ideal, entre a visão de língua de Saussure [objeto social, do qual o indivíduo é escravo] e a de Chomsky [objeto ideal, lugar da liberdade, da criatividade individual, dada a competência lingüística inata de todo falante]. A ampliação da noção desta última inclui, "[...] além do conhecimento de regras gramaticais, a consciência do falante quanto ao 'modus operandi' da língua no contexto social” (Ibid., p.15). É, para ela, a valorização da função social da língua. Afirma, ainda, que a ação do homem sobre o mundo é dotada de intencionalidade e argumentatividade. 
Koch (2004a) explica que a argumentatividade está inscrita na própria língua, pelo fato de o homem ser dotado de razão e vontade e, constantemente, avaliar, julgar, criticar, isto é, formar juízos de valor e tentar influir sobre o comportamento do outro ou fazer com que compartilhe determinadas conclusões. Sua ação sobre o mundo, por isso, é dotada de intencionalidade e em seu discurso subjaz uma ideologia. Ao produzir um discurso, o homem se apropria da língua, não só com o objetivo de veicular mensagem, mas, principalmente, com o objetivo de atuar, de interagir socialmente, instituindo-se como EU e, ao mesmo tempo, como interlocutor, o OUTRO. No caso do texto escrito alguém se fixa como locutor, e o(s) outro(s) como destinatário(s), "[...] não havendo possibilidade de troca (pelo menos, imediata) de papéis entre ambos; predomina, nesse tipo de discurso, uma organização interna, pelo fato de não haver possibilidade de reajustes de relação entre os interlocutores para cada evento particular da enunciação", o que o diferencia do texto falado (lbid., p. 21).

Em cada texto, de acordo com a intencionalidade do enunciador, seriam estabelecidos novos tipos de relações argumentativas que implicam na apresentação de explicações, justificativas, razões. Essas relações discursivas são eminentemente subjetivas, pois dependem das intenções do falante e dos efeitos a que visa ao produzir o seu discurso.

Koch (2004a, p. 21) assevera que "[...] a argumentação constitui atividade estruturante de todo e qualquer discurso, já que a progressão deste se dá, justamente, por meio das articulações argumentativas[...]", desse modo deve-se considerar a orientação argumentativa dos enunciados que compõem um texto como fator básico de coesão e, principalmente, de coerência textual. 
Para a autora, tanto a intencionalidade quanto a argumentatividade estão registradas na língua por meio de marcas lingüísticas - operadores argumentativos, modalizadores -, portanto, para compreender uma enunciação é preciso apreender essas intenções, lingüisticamente constituídas.

Assim, a maioria das relações existentes entre os enunciados componentes de um texto só podem ser detectadas por meio de uma gramática textual ou macrossintaxe do discurso. Encadeando-se uns sobre os outros, de acordo com as intenções do falante e, por conseqüência, com o sentido que se pretende dar ao discurso, os enunciados trazem em seu bojo relações de ordem pragmática, que se revelam, na maioria das vezes, através dos operadores do discurso ou operadores argumentativos - os quais, por meio desse encadeamento, estruturam os enunciados em um texto verbal linear (Ibid., p. 31).

Como afirmamos anteriormente, Koch (2004a) desenvolve estudos e reflexões sobre essas questões, amparada nas pesquisas de Ducrot, Vogt, Guimarães e Weinrich. Na análise do nosso corpus, artigos de opinião produzidos por alunos do ensino fundamental I, buscaremos a presença de algumas dessas marcas discursivas que constituem pistas para se perceber a intencionalidade argumentativa dos respectivos produtores. Para tanto, retomamos os estudos da autora, dando especial atenção àqueles que se mostram pertinentes à nossa pesquisa, pelo fato de terem sido trabalhados com os alunos, nas atividades propostas pelas oficinas, como, por exemplo, as expressões articuladoras, na Oficina 5.

Consideramos impossível pretender avaliar todos os aspectos, sobretudo, levando em conta a faixa etária dos alunos. No entanto, procuraremos não perder de vista o processo em seu conjunto tal qual se apresenta nas fontes teóricas pesquisadas. Para tanto, faremos um recorte teórico, no sentido de operacionalizar instrumentos para uma análise dos resultados obtidos e para sugestões de eventuais reformulações do processo, em fases posteriores. 


\subsubsection{Os tempos verbais no discurso}

Koch (2004a) retoma $\mathrm{H}$. Weinrich, em sua obra Tempus, sobre as formas verbais do francês quanto à função dos tempos verbais no discurso.

O autor alemão constata, ao estudar os tempos verbais do francês, entre outras questões, o fato de eles se distribuírem em dois grupos ou sistemas temporais, com empregos distintos e que não se combinam, normalmente, no mesmo período. São eles ${ }^{19}$ :

Grupo I - Indicativo: presente [canto], pretérito perfeito composto [tenho cantado], futuro do presente [cantarei], futuro do presente composto [terei cantado], além das locuções verbais formadas com esses tempos [estou cantando, vou cantar etc].

Grupo II - Indicativo: pretérito perfeito simples [cantei], pretérito imperfeito [cantava], pretérito mais-que-perfeito [cantara], futuro do pretérito [cantaria] e locuções verbais formadas com tais tempos [estava cantando, ia cantar].

Após estudo de várias situações comunicativas, Weinrich conclui que, da mesma forma que os tempos verbais, as situações comunicativas se dividem em dois grupos: mundo narrado e mundo comentado. Ao primeiro, pertencem todos os tipos de relato, literários ou não. Por se tratar de eventos relativamente distantes, perdem muito de sua força, permitindo, assim, uma atitude "relaxada" (aspas da

\footnotetext{
${ }^{19}$ Os tempos verbais em português foram exemplificados pela autora. Cf. Koch (2004a, p. 35).
} 
autora). Ao segundo, pertencem a lírica, o drama, o ensaio, o diálogo, o comentário, enfim, todas as situações comunicativas que apresentem, como característica, a atitude tensa do falante, pois "[...] se trata de coisas que o afetam diretamente", já que "[...] 'comentar é falar comprometidamente”. O emprego dos verbos comentadores é um alerta para advertir o leitor/ ouvinte de que se trata de algo que o afeta diretamente e de que o discurso exigiria uma resposta $(\mathrm{KOCH}, 2004 \mathrm{a}, \mathrm{p}$. 36).

Observa que, quando se introduz um ou mais tempos do mundo narrado no mundo comentado [ou vice-versa], em inobservância à concordância dos tempos, tem-se a metáfora temporal. Cita, como exemplo, o uso do imperfeito, do passado simples $^{20}$ e do condicional ${ }^{21}$ em situações comentadoras. Essa atitude exprime um matiz de validez limitada, trazendo ao mundo comentado o relaxamento e a falta de compromisso do mundo narrado. "Limita-se, assim, a validez do discurso, pela introdução de matizes que podem exprimir cortesia, timidez, hipótese, incerteza, irrealidade etc". Se, pelo contrário, por exemplo, utilizarmos o presente histórico, em uma narrativa, teremos a validez do fato, algo de tensão, compromisso e seriedade. "Isto é: comenta-se como se se narrasse ou narra-se como se se comentasse."(Ibid., p. 39).

Weinrich (1974, p. 159) afirma que a forma mais conhecida de metáfora temporal é o uso do discurso direto, em que se empregam tempos do grupo I, na narração em que se encontram tempos do grupo II. Considera, neste caso, que "[...] el narrador prefiere el estilo directo cuando quiere conseguir uma presencia más

\footnotetext{
${ }^{20}$ Em português, pretérito perfeito.

${ }^{21}$ Em português, futuro do pretérito.
} 
inmediata y uma participación más íntima del lector. El estilo directo és más vivo que el indirecto."22

O subjuntivo, o imperativo, o gerúndio, o particípio e o infinitivo são considerados semitempos, ou seja, formas que se mostram indiferentes à distinção entre mundo comentado e narrado, por isso não são formas verbais em sua totalidade. Apresentam-se ligados a um tempo pleno, que lhes determina a situação comunicativa, podendo fixar a perspectiva ou estabelecer relevo.

Koch (2004a) afirma que a adequação desses estudos para o português é válida, considerando como problema o fato de nossa língua apresentar elevado índice de incidência do pretérito perfeito tanto no relato como no comentário e acrescenta:

Somos de opinião que, quando a co-ocorrência do perfeito simples com tempos do mundo comentado não se dá dentro do mesmo período, é possível considerar tais empregos como momentos narrativos dentro do comentário: introduz-se um relato para servir de base a um comentário posterior, ou se faz o comentário, acrescentando-se, a seguir, um argumento ou uma exemplificação em forma de relato (lbid., p. 41).

A autora, com base na posição de Bull (1960) a respeito da forma espanhola "cantó", acrescenta: "[...] nos casos em que o pretérito perfeito co-ocorre com tempos do comentário dentro de um mesmo período, fato bastante freqüente em português, somos de opinião que se trata de um tempo do mundo comentado[...]", ocorre uma neutralização entre duas formas diversas; "[...] a que constitui, em nossa língua, o tempo zero do mundo narrado e a que representa a perspectiva retrospectiva em relação ao tempo zero no mundo comentado"(lbid., p. 42).

Os textos que compõem nosso corpus pertencem ao gênero textual artigo de opinião, que apresenta predominância de uma situação comunicativa do mundo

\footnotetext{
${ }^{22}$ Tradução: "[...] o narrador prefere o estilo direto quando quer conseguir uma presença mais imediata e uma participação mais íntima do leitor. O estilo direto é mais vivo que o indireto."
} 
comentado, onde se manifesta a opinião do autor sobre um tema polêmico, devendo, portanto, apresentar tempos do Grupo I, por pretender criar uma atitude tensa do enunciador, um comprometimento. O artigo trata de coisas que afetam diretamente o enunciador e o discurso exige uma resposta do leitor.

A análise da ocorrência desses tempos será feita no capítulo referente à análise do corpus, auxiliado pelo quadro do anexo 2.

\subsubsection{Operadores argumentativos}

Koch (2004a, p. 102) assevera que "[...] a argumentatividade não constitui apenas algo acrescentado ao uso lingüístico, mas, pelo contrário, está inscrita na própria língua, ou seja, [...] o uso da linguagem é inerentemente argumentativo. Além do que, todo enunciado tem como característica constitutiva o fato de se apresentar como orientando a seqüência do discurso, determinando encadeamentos possíveis para continuá-lo, alguns são empregados com a pretensão de orientar o interlocutor para certos tipos de conclusão, com exclusão de outras igualmente possíveis.

A autora afirma que existem, na gramática de cada língua, morfemas responsáveis por esse tipo de relação, os operadores argumentativos ou discursivos que, em alguns casos, são considerados pelas gramáticas tradicionais como elementos meramente relacionais - conectivos, como mas, porém, embora, já que, pois ou, até mesmo, não são enquadrados pela N.G.B. ${ }^{23}$ em nenhuma das dez classes de palavras. Esclarece que "é a macrossintaxe do discurso ou semântica argumentativa que vai recuperar esses elementos, por serem justamente eles que

\footnotetext{
23 Segundo a autora, Rocha Lima chama-os de palavras denotativas, Bechara, de palavras de inclusão [até mesmo, também, inclusive]; de exclusão [só, somente, apenas, senão]; de retificação [aliás, ou melhor, isto é]; de situação [afinal, então], Celso Cunha de palavras “essencialmente afetivas” (Cf. KOCH, 2004a, p. 103).
} 
determinam o valor argumentativo dos enunciados, constituindo-se, pois, em marcas lingüísticas importantes da enunciação"24 (Ibid., p.103).

Dada a validade da análise dos operadores argumentativos, em nosso estudo reproduziremos o seu exame como é proposto pela autora, em Argumentação e Linguagem (2004a), complementados por análises presentes em sua outra obra: $A$ Inter-ação pela Linguagem (2004c) :

1. Estabelecem hierarquia dos elementos numa escala, assinalando o argumento mais forte no sentido de uma determinada conclusão $\mathbf{r}-$ mesmo, até, até mesmo, inclusive - ou, então, mais fraco - ao menos, pelo menos, no mínimo.

2. Havendo dois ou mais argumentos orientados no mesmo sentido, seus elementos podem ser encadeados por meio de operadores que somam argumentos a favor de uma mesma conclusão como $e$, também, nem, tanto ... como, não só ..mas também, além de, além disso, etc.

3. $\quad \operatorname{Ainda}^{25}$, já e agora introduzem conteúdos pressupostos.

Ainda pode servir como marcador de excesso temporal/ não temporal e introdutor de mais um argumento a favor de determinada conclusão.

\footnotetext{
${ }^{24}$ A autora considera conveniente, para um exame desses morfemas, retomar a noção de classe e escala argumentativa formulada por Ducrot. "Dois ou mais argumentos orientados no mesmo sentido, isto é, para uma mesma conclusão, constituem uma classe argumentativa. Diz-se que p é um argumento para a conclusão r, se pé apresentado como devendo levar o interlocutor a concluir $\mathbf{r}$. Quando vários argumentos - p, p',p',... - se situam numa escala graduada, apontando, com maior ou menor força, para a mesma conclusão r, diz-se que eles pertencem à mesma escala argumentativa $(\mathrm{KOCH}, 2004 \mathrm{a}, \mathrm{p} .103)$.

${ }^{25}$ Koch (2004a) cita, como exemplo: Paulo mora no Rio./ Paulo ainda mora no Rio./ Paulo já mora no Rio./ Paulo agora mora no Rio.
} 
Já, agora podem ser empregados como indicadores de mudança de estado.

4. Aliás, além do mais introduzem, de maneira subreptícia, um argumento decisivo, apresentando-o a título de acréscimo.

5. Isto é, quer dizer, em outras palavras visam a esclarecer, retificar, desenvolver, ajustar, precisar.

6. Operadores que se distribuem em escalas opostas: Tudo, todos para escalas orientadas no sentido de uma afirmação plena; nada, nenhum, negação plena. Pouco orienta no sentido da negação, da restrição e um pouco, no sentido da afirmação. Quase ${ }^{26}$ aponta para a afirmação da totalidade e apenas, para a negação da totalidade.

7. Portanto, logo, por conseguinte, pois, em decorrência, conseqüentemente, e sinônimos, são operadores que introduzem uma conclusão relativa a argumentos apresentados em enunciados anteriores.

8. Ou, ou então, quer ... quer, seja ... seja introduzem argumentos alternativos que levam a conclusões diferentes ou opostas.

9. Mais que, menos que, tão ... como, etc estabelecem relações de comparação entre elementos, com vistas a uma dada conclusão.

\footnotetext{
${ }^{26}$ Koch $(2004 \mathrm{c})$ alerta para o fato de certos operadores obedecerem a regras combinatórias como, por exemplo, quase que combina com a maioria, ao passo que apenas permite seu encadeamento com poucos.
} 
10. Porque, que, já que, pois, etc introduzem uma justificativa ou explicação relativa ao enunciado anterior.

11. Mas $^{27}$, porém, contudo, todavia, entretanto e embora ${ }^{28}$, ainda que, posto que, apesar de (que), etc contrapõem argumentos orientados para conclusões contrárias.

A autora conclui, reiterando a importância do estudo desses operadores, pois grande parte da força argumentativa do texto depende dessas marcas lingüísticas que, ao selecionarem "[...] enunciados capazes de constituírem a seqüência do discurso, são responsáveis pela sua orientação argumentativa global, no sentido de levarem o interlocutor a um determinado tipo de conclusões em detrimento de outras" (KOCH, 2004a, p. 107):

Evidencia-se, portanto, que essas instruções, codificadas, de natureza gramatical, supõem evidentemente um valor retórico da construção, ou seja, um valor retórico - ou argumentativo - da própria gramática. $\mathrm{O}$ fato de se admitir a existência de relações retóricas ou argumentativas inscritas na própria língua é que leva a postular a argumentação como ato lingüístico fundamental (lbid., p. 107).

Nossos estudos constataram a presença de vários operadores argumentativos, nos textos, que compõem nosso corpus; principalmente, os trabalhados nas oficinas, conforme se verificará no quadro do anexo 5 na página 221. Em capítulo posterior, examinaremos em detalhe essas marcas argumentativas.

\footnotetext{
27 A autora afirma que mas é considerado por Ducrot “o operador argumentativo por excelência”e assim explica seu esquema de funcionamento: o locutor introduz em seu discurso um argumento possível, com o qual não se engaja, que pode ser atribuído a terceiros, a um determinado grupo ou ao saber comum de determinada cultura; a seguir, opõe-lhe um argumento decisivo para a conclusão contrária, ao qual adere.

${ }^{28}$ Segundo Koch (2004c), existe uma diferença entre os operadores do grupo do mas e os do grupo do embora. No caso do mas, cria-se um suspense por se apresentar uma conclusão R, para depois introduzir o argumento que levará o interlocutor à conclusão R'; ao empregar embora, o locutor antecipa que o argumento introduzido por esse operador vai ser anulado.
} 


\subsubsection{Modalidades do discurso}

Koch ( 2004a) afirma que, na estruturação do discurso, a relação entre os enunciados é freqüentemente projetada a partir de certas relações de modalidade e que, em seu trabalho, essa questão é enfocada sob o ponto de vista da pragmática lingüística, pois consideram-se as modalidades como parte da atividade ilocucionária ${ }^{29}$ por revelarem a atitude do falante perante o discurso que produz. Em outras palavras, retoma ela, ao produzir um discurso, o enunciador manifesta suas intenções e sua atitude diante dos enunciados que produz por meio de sucessivos atos ilocucionários de modalização, dotados de valor argumentativo. Esses atos se atualizam por meio dos diversos modos de lexicalização que a língua oferece, os operadores modais.

Considera que o recurso às modalidades permite ao locutor marcar a distância relativa em que se coloca com relação ao enunciado que produz, seu grau de engajamento com relação ao que é dito, determinado o grau de tensão estabelecido entre os interlocutores; permite que ele deixe "pistas" [aspas da autora] quanto às suas intenções e possibilita, também, modalizar atos produzidos por outras "vozes" [aspas da autora], provenientes de enunciadores diferentes.

a) performativos explícitos: eu ordeno, eu proíbo, eu permito, etc;

b) auxiliares modais: poder, dever, querer, precisar, etc;

c) predicados cristalizados: é certo, é preciso, é necessário, é provável, etc;

d) advérbios modalizadores: provavelmente, certamente, necessariamente, possivelmente, etc;

\footnotetext{
${ }^{29}$ Ato ilocucionário é a "força” com que os enunciados são produzidos. (Cf. KOCH, 2004a, p.18)
} 
e) formas verbais perifrásticas: dever, poder, querer, etc. + infinitivo;

f) modos e tempos verbais: imperativo; certos empregos de subjuntivo; uso do futuro do pretérito com valor de probabilidade, hipótese, notícia não confirmada; uso do imperfeito do indicativo com valor de irrealidade, etc;

g) verbos de atitude proposicional: eu creio, eu sei, eu duvido, eu acho, etc;

h) entonação: ocorre na linguagem oral e permite distinguir uma ordem de um pedido;

i) operadores argumentativos: pouco, um pouco, quase, apenas, mesmo, etc;

Quanto às modalidades que, segundo a autora, apresentam um caráter ilocucionário argumentativo, tem-se ${ }^{30}$ :

a) Modalidades aléticas: necessidade: é necessário;

b) Modalidades epistêmicas: crença: probabilidade e certeza;

c) Modalidades deônticas: conduta, normas - obrigatoriedade e permissividade: é obrigatório, é permitido;

d) Modalidade imperativa: obrigação e permissão: eu ordeno, eu permito;

e) Modalidade assertiva: afirmação;

f) Modalidade cognitiva: possibilidade.

\footnotetext{
${ }^{30}$ Koch recorre ao trabalho de GUIMARÃES, E. R. J. (1979). Modalidade e argumentação lingüística. Tese de doutorado, São Paulo, FFLCH da USP e acrescenta que para que se tornasse viável estabelecer a exata correspondência das diversas modalidades com os atos de linguagem possíveis, seria preciso que se tivesse uma tipologia exaustiva destes, o que ainda não se concretizou.
} 
Todos esses recursos lingüísticos [formas verbais, situações comunicativas, operadores argumentativos e modalidades do discurso entre outros], utilizados pelo produtor do texto, funcionam, como vimos, como indicadores de suas intenções, de seus sentimentos e de suas atitudes em relação ao seu discurso [nas análises do corpus, adiante, ilustramos o uso de alguns desses recursos]. Os estudos dessas marcas são importantes aliados não só para uma leitura crítica dos discursos, permitindo-nos "[...] percebê-las no discurso do outro[...]" (KOCH, 2004a, p. 108), alertando-nos contra os "[...] simulacros discursivos[...]" (MOSCA, 2004b, p. 50), como também para a produção de textos argumentativos eficazes que cumpram a função não só de convencer com argumentos racionais, mas também de persuadir, mediante argumentos de caráter emocional.

Koch (2004a) assevera que o fato de tentar minimizar a importância dessas marcas, não conscientizando o usuário da língua do seu valor argumentativo, dando pouca atenção a elas nos livros didáticos ou nas aulas de língua portuguesa (KOCH, 2004c, p. 39), "[...] pode ser interpretado, até mesmo, como uma postura de caráter ideológico" (KOCH, 2004a, p. 108). Ela sugere, a nosso ver, que ensinar a argumentar seria uma maneira de formar cidadãos críticos e conscientes. 


\subsection{Heterogeneidade no discurso}

Quanto a mim, em tudo eu ouço 'vozes' e relações dialógicas entre elas.

(Bakhtin)

Assumimos, nesta pesquisa, embasados nos trabalhos desenvolvidos por Perelman (2004; 2005), Mosca (2004) e Koch (2004) que a argumentatividade está inscrita na própria língua. Não será diferente nossa posição quanto ao dialogismo e à polifonia, apoiados nos estudos de Bakhtin (2003; 2004) e de Authier-Revuz (1990). Para o autor de Estética da Criação Verbal, tanto o dialogismo quanto a polifonia fazem parte das interações verbais como condição constitutiva do sentido.

A vida é dialógica por natureza. Viver significa participar do diálogo: interrogar, ouvir, responder, concordar, etc. Nesse diálogo o homem participa inteiro e com toda a vida: com os olhos, os lábios, as mãos, a alma, o espírito, todo o corpo, os atos. Aplica-se totalmente na palavra, e essa palavra entra no tecido dialógico da vida humana, no simpósio universal (BAKHTIN, 2003, p. 348)

Brandão (2002, p. 51) afirma que Bakhtin elabora sua teoria da polifonia, baseado no pressuposto de que o ser humano é inconcebível fora das relações que o ligam ao outro. É pelo fenômeno social da interação verbal, realizada por meio de enunciados e enunciações que se toma consciência de si mesmo, através dos outros. "Eu tomo consciência de mim e me torno eu mesmo unicamente me revelando para o outro, através do outro e com o auxílio do outro" (BAKHTIN, 2003, p. 341).

Bakhtin (2003) considera que tudo o que diz respeito ao homem, a começar pelo seu nome, chega do mundo exterior à sua consciência, pela boca dos outros. É pelas palavras que se recebe do outro, que se forma a imagem de si mesmo. A palavra, para o autor, é plurivalente e o dialogismo é uma condição constitutiva do 
sentido, como já afirmamos. "Nenhuma palavra é 'neutra', mas inevitavelmente 'carregada', 'ocupada', 'habitada', 'atravessada' pelos discursos nos quais 'viveu sua existência socialmente sustentada' " (AUTHIER-REVUZ, 1990, p. 27).

Para o autor russo, o dialogismo tem uma dupla orientação: a primeira voltada para os outros discursos como processos constitutivos do próprio discurso; a segunda voltada para o outro da interlocução, o destinatário. Ressaltamos que é nesse primeiro aspecto que se constitui, segundo Authier-Revuz (1990, p. 26), "[...] uma teoria da dialogização interna do discurso", ou seja, na fala de cada um, outras vozes também falam: "as palavras são, sempre e inevitavelmente, 'as palavras dos outros"”.

Bakhtin (2003) afirma que não pode haver enunciados isolados. Eles sempre pressupõem enunciados que os antecedem e os sucedem, nenhum enunciado é o primeiro nem o último, mas apenas um elo na cadeia. Dessa forma, os outros discursos, "[...] fios dialógicos vivos [...]" constitutivos de todo discurso, tecem-se "[...] polifonicamente, num jogo de várias vozes cruzadas, complementares, concorrentes, contraditórias" (BRANDÃO, 2002, p. 53). Bakhtin assevera que não existe a primeira nem a última palavra e que não há limite para o contexto dialógico. Na relação criadora com a linguagem, não há palavra sem voz, "em cada palavra há vozes às vezes infinitamente distantes, anônimas, quase impessoais [...] quase imperceptíveis, e vozes próximas, que soam concomitantemente" (BAKHTIN, 2003, p. 330).

Somente o Adão mítico, abordando com sua primeira fala um mundo ainda não posto em questão, estaria em condições de ser ele próprio o produtor de um discurso isento do já dito na fala do outro (BAKHTIN, M. "Questions de litterature et d'esthétique" Moscou, 1975. Trad. Fr. Esthétique et théorie du roman, Gallimard, Paris, 1978 apud AUTHIER-REVUZ, 1990, p.27). 
Sendo assim, todo discurso é heterogêneo, é o produto de interdiscursos assim como todo sujeito que o produz. Authier-Revuz (1990) chama a essa característica do discurso de heterogeneidade constitutiva. Nessa perspectiva, o conceito de subjetividade não pode estar centrado num "eu" absoluto, mas num sujeito "[...] partícula de um corpo histórico-social no qual interage com outros discursos de que se apossa ou diante dos quais se posiciona (ou é posicionado) para construir sua fala" (BRANDÃO, 2002, p. 54).

Em Heterogeneidades Enunciativas, Authier-Revuz (1990) faz uma articulação entre o conceito de "dialogismo"31 do círculo de Bakhtin e a releitura de Freud, feita por Lacan, sobre o aspecto psicanalítico de um sujeito dividido e de uma fala heterogênea, fruto da descoberta do inconsciente pelo sujeito que "[...] não é mais senhor de sua morada [...]" (Ibid., p. 29). A partir desses conceitos, apresenta um estudo sobre a heterogeneidade própria do discurso a qual divide em: mostrada e constitutiva.

A heterogeneidade constitutiva, citada anteriormente, é própria de todo discurso, pois o sujeito é deslocado "[...] em um lugar múltiplo [...]", fundamentalmente heterônimo, “[...] em que a exterioridade está no interior do sujeito"; constitutivamente, no sujeito e no seu discurso está o outro (lbid., p. 29)

Sempre sob as palavras, "outras palavras" são ditas: é a estrutura material da língua que permite que, na linearidade de uma cadeia, se faça escutar a polifonia não intencional de todo discurso, através da qual a análise pode tentar recuperar os indícios da "pontuação do inconsciente" (AUTHIER-REVUZ, 1990, p. 28).

\footnotetext{
${ }^{31}$ A autora esclarece que o círculo de Bakhtin não tem preocupação central com o diálogo face a face, mas com aquele que se constitui por meio de uma reflexão multiforme, semiótica e literária, uma teoria da dialogização interna do discurso (AUTHIER-REVUZ, 1990, p. 26).
} 
Já a heterogeneidade mostrada inscreve o outro na seqüência do discurso. Authier descreve algumas formas de heterogeneidade que acusam essa presença. São elas:

a) Explícitas: discurso relatado - discurso direto, discurso indireto e conotação autonímica: aspas, itálico, glosa; comentário [inscrição da palavra do outro sem quebra da estrutura sintática];

b) Implícitas: discurso indireto livre, ironia antífrase, alusão, imitação, reminiscência [sem fronteira lingüística nítida entre a voz do locutor e a do outro].

Para ela, essas marcas, essa zona de contato entre exterior e interior do discurso são profundamente reveladoras. As formas marcadas, escolhidas para evidenciar explicitamente essas fronteiras, são, ao mesmo tempo, um sintoma e uma defesa, por dois motivos: em primeiro lugar, para perceber de que outro é preciso se defender, a que outros é preciso recorrer para se constituir; e, em segundo lugar, pelo tipo de relação que aí se joga com o outro:

[...] um discurso teórico, por exemplo, para ultrapassar a tecedura dos discursos pré-existentes na qual ele é tomado e na qual ele se faz, da marcação de posição de afrontamento polêmico, de uma "luta pela vida" quando o que se joga na zona de contato não é a ordem da discussão [...] mas o direito à existência para um dos dois apenas (AUTHIER-REVUZ, 1990, p. 31).

Há uma negociação entre as duas formas de heterogeneidade. O sujeito, impossibilitado de fugir da heterogeneidade constitutiva de todo discurso, ao explicitar a presença do outro, através das marcas da heterogeneidade mostrada, expressaria, na verdade, seu desejo de dominância. Movido pela ilusão do centro, por um processo de denegação, localiza o outro e delimita seu lugar. Essas marcas 
confirmam um "eu" que se coloca como sujeito de seu discurso; por esse ato individual de apropriação que introduz aquele que fala em sua fala, dá forma ao sujeito enunciador e corpo ao discurso (Ibid., p. 33).

Nesse sentido, para Bakhtin (2003, p. 380), “a palavra deve transformar-se em minha-alheia“. As palavras do outro, assimiladas, renovam-se criativamente em novos contextos, tudo que é dito é um "já-dito”, como afirma Brandão (2002, p.67).

Considerando os aspectos polifônicos e dialógicos, constitutivos do sentido do discurso, analisaremos, em nosso corpus, esse embate de vozes sociais que são reveladoras do conhecimento de mundo do aluno, adquirido por meio de suas relações sociais e da apropriação de informações, seja em contato com adultos à sua volta, seja em atividades propostas pelas oficinas, sobre a questão polêmica tratada em seu texto. Verificaremos também a coerção dessas e de outras vozes [possivelmente do professor e/ ou de outros adultos] sobre o discurso dos alunosprodutores dos artigos de opinião semifinalistas. Cabe lembrar que a análise da utilização dessas vozes sociais com função argumentativa é fundamental, não só pelo fato de que a argumentação está inscrita na própria língua, mas também porque compõe um dos critérios de avaliação do concurso. 
CAPÍTULO II

PRÊMIO ESCREVENDO O FUTURO - 2004 


\subsection{Apresentação do Concurso}

Esta descrição tem o objetivo de apresentar o Prêmio Escrevendo o Futuro, com a preocupação de não perder o espírito dos textos produzidos pela equipe organizadora que procura envolver os professores, figuras importantes desse projeto, pelo fato de serem os principais responsáveis pelo seu sucesso.

O tema do projeto, em 2004, foi "O lugar onde vivo", utilizado para produzir textos nos seguintes gêneros: artigos de opinião, poemas e memórias, o primeiro deles, objeto deste estudo.

O conjunto de materiais que compõe o Prêmio - Kit Itaú de Criação de Textoé constituído por um caderno, Cá entre nós, e três fascículos: Pontos de vista (para texto de opinião), Poetas da escola (para poesia) e Se bem me lembro... (para memórias). Limitamo-nos, aqui, ao caderno Cá entre nós e ao fascículo Pontos de Vista. 


\subsection{Caderno Cá entre nós ${ }^{32}$}

\subsubsection{Orientações iniciais}

O caderno Cá entre nós é composto por onze páginas que apresentam o Prêmio Escrevendo o Futuro - 2004 e traz os seguintes tópicos:

a) Escrever: um convite irrecusável;

b) Organização da escola;

c) O Kit Itaú de Criação de textos:

- A escolha do gênero;

- A produção de textos na sala de aula;

- A Comissão Julgadora da escola;

- Os critérios de avaliação: poema; artigo de opinião e texto de memórias;

- O anúncio dos melhores textos da escola;

- Um dedo de prosa com o diretor da escola.

Assim começa a apresentação do material que, como afirmam as autoras, objetiva apoiar os professores em sua tarefa de ensinar a escrita, em sala de aula, e fornecer orientações para a organização de todo o trabalho na escola.

Escrever. Transformar pensamentos em palavras. Tirar o branco do papel e contar histórias sem fim. Misturar sentimentos com letras e construir uma poesia. Registrar para o mundo uma opinião. Transformar o lápis em uma lupa, investigar lugares e acontecimentos, produzir memórias, histórias de vida que nos levam a lugares e tempos desconhecidos. Usar ponto, vírgula, parágrafo e travessão e tudo o mais que for necessário para dar forma aos textos elaborados. Enfim, escrever e reescrever é o desafio que o Prêmio Escrevendo o

\footnotetext{
${ }^{32}$ O Prêmio Escrevendo o Futuro, em 2007, conta com o site www.escrevendoofuturo.org.br. onde encontramos vários links com: orientações do Prêmio 2006; textos semifinalistas; textos de formação; página interativa etc.
} 
Futuro propõe às crianças brasileiras, alunos de $4^{\text {as }}$ e $5^{\text {as }}$ séries das escolas públicas de todo o país.

Os organizadores informam que as atividades propostas, nos fascículos, significam uma contribuição do Prêmio Escrevendo o Futuro para o ensino da escrita na escola e visam a aprimorar esse trabalho, para ser aproveitadas por todos os que tenham interesse em melhorar a qualidade da educação pública brasileira, até mesmo, ser utilizadas em reuniões pedagógicas da escola. Esclarecem que essas atividades e orientações estão sintonizadas com as diretrizes contidas nos currículos oficiais mais recentes de Língua Portuguesa, inclusive nos Parâmetros Curriculares Nacionais - PCNs.

Os fascículos apresentam oficinas com as respectivas atividades, seus objetivos e as descrições de situações e tarefas para que os professores possam orientar seus alunos a: conhecer melhor o lugar onde vivem; aprimorar as características dos gêneros priorizados; produzir seus textos e auto-avaliar a escrita elaborada.

No final de cada fascículo, são apresentados alguns modelos de textos, que serão lidos e analisados pelos alunos, nas oficinas, e por papéis timbrados nos quais será transcrito, pelo próprio aluno, o texto que participará das várias fases do concurso.

As orientações enfatizam a necessidade de envolver toda a escola: professores, pais, alunos, funcionários e pessoas da comunidade, pois todos podem contribuir para o sucesso na produção de textos. A equipe organizadora considera importante apresentar o Prêmio Escrevendo o Futuro, seus objetivos, as etapas, os prazos e os materiais de apoio para todas as pessoas envolvidas que deverão ser informadas, regularmente, sobre o andamento das atividades. 
A escolha do gênero cabe aos professores e exige a leitura antecipada dos três fascículos [Pontos de Vista, Poetas da escola e Se bem me lembro], pois eles só estarão em condições de encaminhar a discussão com os alunos e de integrá-los para a escolha da alternativa mais adequada às características de cada grupoclasse, a partir do momento em que tiverem uma idéia das propostas.

Os autores justificam a necessidade do envolvimento do maior número possível de professores, pois dessa forma poderá haver um trabalho interdisciplinar: o professor de Geografia realizaria um estudo do meio com os alunos; o de História poderia colaborar no levantamento da história da cidade e de histórias de vida, orientando os alunos a realizar entrevistas e pesquisas; o de Ciências ajudaria efetuando uma análise das condições ambientais da cidade etc.

O diretor da escola, segundo os organizadores, é a figura-chave de todo o percurso do Prêmio, pois é ele quem apoiará os professores, na busca de alternativas para superar eventuais dificuldades, nos esforços para mobilizar a equipe escolar e a comunidade em torno do processo e da aprendizagem da escrita, na divulgação das conquistas e das produções realizadas.

Como o que está em jogo é aprender a escrever, a equipe organizadora solicita que o acompanhamento do progresso dos alunos seja feito por meio de registros sistemáticos de avanços e dificuldades observados; e que se organize uma pasta com as produções da classe. Essas ações subsidiarão os professores no planejamento de novas intervenções, visando ao contínuo aperfeiçoamento da produção escrita de todos os alunos. Os organizadores orientam sobre a necessidade de arquivar os textos produzidos, pois o texto vencedor deverá ser enviado juntamente com as primeiras produções feitas pelo seu autor. 
A Comissão Julgadora da escola terá a tarefa de ler e analisar os textos dos vencedores das classes participantes e escolher o melhor para ser enviado à União dos Dirigentes Municipais [Undime]. Independentemente do gênero, a escola escolherá um único texto para representá-la na seleção estadual.

Essa Comissão deverá ser composta por no mínimo quatro pessoas, representantes da comunidade e da escola como, por exemplo: um representante dos pais; um representante dos professores que não esteja diretamente envolvido no concurso; um representante dos alunos que também não esteja envolvido diretamente no concurso; um morador da cidade que utilize a escrita no seu trabalho, um jornalista, por exemplo, e um integrante da direção da escola. A diversidade fortalecerá a lisura e a transparência das decisões e dos encaminhamentos.

Aconselha-se que os avaliadores, membros da Comissão Julgadora da Escola, mantenham coerência e valorizem os mesmos aspectos e critérios priorizados pelos professores nas oficinas. Asseveram ser de fundamental importância que todos os membros sigam as mesmas orientações, de modo que seja eliminada a subjetividade na escolha. Para tanto, o material fornece três tabelas com critérios de avaliação, uma para cada gênero, que orientam na atribuição de pontos aos textos avaliados.

No caso dos artigos de opinião, a avaliação deve considerar, sobretudo, se o texto busca convencer ${ }^{33}$. Dividem o valor total do texto, dez pontos, em dois grupos, assim dispostos: 7 pontos atribuídos aos aspectos próprios do gênero e 3 pontos atribuídos aos aspectos mais gerais do texto, conforme tabela abaixo:

\footnotetext{
${ }^{33}$ Uma das questões que procuraremos verificar, além de outras, é se os textos analisados só buscam convencer, apresentando argumentos que apelam para a razão ou se também procuram persuadir o leitor por meio da emoção.
} 


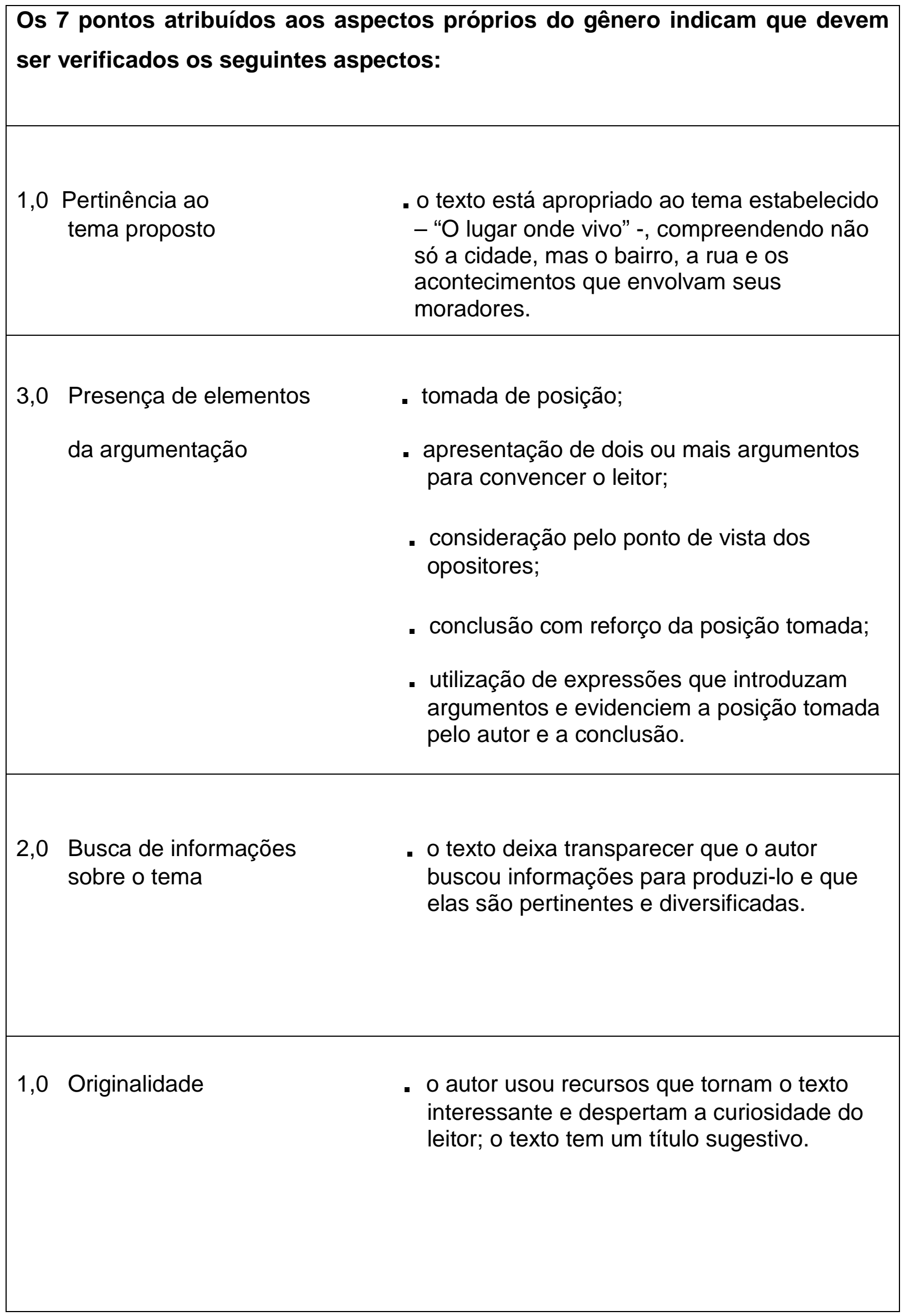


Os 3 pontos atribuídos aos aspectos mais gerais do texto são relacionados a:

$\begin{array}{ll}3,0 \text { Aspectos gerais de } & \text {. concordância verbal; } \\ \text { gramática e ortografia } & \text {. concordância nominal; } \\ & \text {. uso do pronome; } \\ \text {. pontuação; } \\ \text {. uso de maiúscula; } \\ \text {. uso de parágrafo; } \\ \text {. correção ortográfica. }\end{array}$

Nossa pesquisa centrar-se-á na análise e verificação da presença de elementos da argumentação, segundo item da tabela, nos textos semifinalistas do Pólo São Paulo. Esses aspectos são fundamentais na construção do artigo de opinião, além de ser um dos critérios utilizados para a avaliação feita pela Comissão Julgadora.

Escolhido o texto vencedor, os organizadores do concurso sugerem que os melhores textos da escola também sejam homenageados, num evento bem planejado, buscando o reconhecimento, pelas pessoas da comunidade, dos trabalhos que mais se destacaram. Sugerem ainda, se possível, a publicação dos textos no jornal da cidade ou da região.

O envelope contendo o texto vencedor, juntamente com os primeiros textos produzidos pelo aluno, será encaminhado à Undime, entidade parceira do Prêmio Escrevendo o Futuro, pelo diretor da escola. 


\subsection{Fascículo Pontos de Vista - Texto de opinião}

O fascículo Pontos de Vista é composto por:

a) Apresentação feita pelo Presidente da Fundação Itaú Social;

b) Carta ao professor;

c) Sumário;

d) Opinião no cotidiano;

e) Sobre o artigo de opinião;

f) Oficinas.

\section{a) Apresentação do Programa Itaú Social}

Roberto Egydio Setúbal, Presidente da Fundação Itaú Social faz a apresentação do Programa, afirmando que a educação é um direito fundamental de cada cidadão e que a iniciativa privada pode e deve colaborar, agora e no futuro, para a construção de uma sociedade que crie e amplie oportunidades para crianças e jovens brasileiros. Assevera que é, nesse contexto, que se insere a Fundação Itaú Social, desenvolvendo e apoiando programas na área de educação pública, especificamente, no ensino fundamental.

Esclarece que o Programa Escrevendo o Futuro é o resultado desse entendimento. Ele se organiza por meio de um conjunto de ações voltadas à melhoria da produção escrita nas escolas públicas brasileiras, uma vez que a conquista das habilidades da leitura e da escrita significa um fator determinante de inclusão social e de sucesso para os jovens cidadãos na vida cotidiana e no mercado de trabalho. 
O Presidente afirma que, em anos pares, o Programa Escrevendo o Futuro premia alunos, professores e escolas por meio de um concurso de textos desenvolvidos, nas salas de aula, em oficinas de formação e que, nos anos ímpares, promove ações para aprimorar a formação dos professores, fornecendo subsídios para o ensino e a leitura.

\section{b) Carta ao professor}

$\mathrm{Na}$ carta de apresentação dos fascículos, as autoras apresentam o tema do concurso e dizem que os organizadores do Prêmio idealizaram a produção de algumas publicações: uma de memórias, histórias de pessoas de diferentes lugares do Brasil; outra de textos em que os alunos defendam opiniões sobre assuntos diversos; e outra de poemas. Dessa forma, o aluno vai escolher e produzir textos bem específicos.

Afirmam que escrever memórias a partir de entrevistas com pessoas mais velhas sobre o lugar onde vivem é muito diferente de escrever um artigo de opinião ou um poema. A finalidade da elaboração de cada gênero é bastante específica, o que determina que apresentem características bem particulares. O texto de opinião, por exemplo, tem como finalidade convencer alguém de alguma coisa. $\mathrm{O}$ autor assume uma posição a favor ou contra uma questão que provoca discussões, debates, ou seja, a respeito da qual costuma haver pontos de vista discordantes.

Dizem que, muitas vezes, quando propomos que nossos alunos escrevam, não damos a essa escrita uma finalidade clara, nem estimulamos sua circulação fora da escola. Os leitores das produções são, quase sempre, apenas os professores, 
isso contribui para padronizar as produções escolares. A redação é feita na escola e para a escola.

Esclarecem que a proposta desse material parte do princípio de que as condições de produção da escrita e a finalidade dos textos devem ficar claras para os alunos, como também o fato de que eles serão publicados e lidos por muitas pessoas. Esses esclarecimentos farão com que os alunos compreendam que é preciso escrever corretamente, com capricho. Se muitas pessoas lerão as produções, é necessário que sejam legíveis.

Asseveram que, ao preparar os alunos para esta tarefa, não se espera que eles escrevam como adultos. O que se espera é que escrevam poemas, memórias sobre o lugar onde vivem ou textos de opinião que revelem o próprio ponto de vista sobre o tema tratado. As orientações organizadas são válidas não só para o concurso, mas também para o dia-a-dia na escola. A escrita deve ser feita a partir de uma situação de produção próxima àquelas da vida real que ocorrem fora do espaço escolar. Consideram que cada situação de produção propõe respostas diversas às questões: o que vou escrever? para quem? com qual finalidade? qual a posição do meu interlocutor? como devo me dirigir a ele? ${ }^{34}$ Por isso, o encaminhamento de cada gênero exige orientação e direcionamento específicos.

Afirmam que tanto os professores quanto os organizadores do Prêmio e autores do material de apoio são os mediadores cuja tarefa maior é contribuir para a melhoria da qualidade da educação brasileira. Os organizadores desejam que as sugestões possam ser úteis e que todos se "empolguem com a participação no concurso, trabalhem bastante animados" e façam um bom trabalho que tenha prosseguimento, independentemente dos vínculos com o prêmio.

\footnotetext{
${ }^{34}$ Retomam proposta de Dolz e Schneuwly refletida nos PCNs. Como afirmam Roxane Rojo e Glaís Sales Cordeiro, neles " [...] passam a ter importância tanto as situações de produção e de circulação do texto como a significação que neles é forjada" (SCHNEUWLY; DOLZ, 2004, p.11).
} 


\section{c. Sumário}

Trata-se de indicador que facilita o manuseio do material.

\section{d. Opinião no cotidiano}

Neste item, as autoras afirmam que, pelo fato de vivermos em conjunto, dar opinião sobre questões cotidianas é uma atitude corriqueira. Mas há situações em que essas opiniões são manifestadas na esfera pública e exigem um planejamento do que se vai dizer como, por exemplo, em debates políticos na televisão. Uma opinião não se restringe à fala, em jornais e revistas, também é dada por escrito, em seções como cartas de leitores, artigos de opinião e editoriais: textos que exprimem a posição do leitor, do jornal ou do articulista sobre dada questão.

Os artigos jornalísticos de opinião são importantes instrumentos para a formação do cidadão. Aprender a ler e a escrever esse tipo de texto, na escola, contribui não só para desenvolver a capacidade de participar de discussões sobre as questões do lugar onde se vive, com argumentos convincentes, como também, se informar, formar opinião sobre elas e contribuir para resolvê-las.

\section{e. Sobre o artigo de opinião}

A proposta do material é trabalhar com artigo de opinião, um gênero argumentativo escrito, publicado em jornais, revistas e internet. Por esse motivo, as autoras propõem, primeiramente, uma reflexão sobre esse gênero. Justificam, dizendo que o conhecimento que o professor adquirir sobre as características do 
gênero textual "artigo de opinião" dará a ele a possibilidade de auxiliar os alunos, desenvolvendo um bom trabalho com leitura e escrita desse gênero na escola.

Notamos que essas reflexões demonstram uma clara preocupação dos organizadores com a formação dos professores, possivelmente, por considerarem que nem todos os profissionais envolvidos no concurso dominem a concepção de ensino, por meio do trabalho com os gêneros, principalmente, pelo fato de o prêmio ter uma abrangência nacional. Basta verificar a procedência dos textos vencedores: eles representam as mais diversas regiões do país.

Segundo as autoras, a produção de um artigo de opinião pressupõe a existência de uma situação social de comunicação em que estejam envolvidos um jornal ou uma revista, seu editor, um articulista convidado e leitores interessados em conhecer a opinião do referido articulista que, normalmente, não faz parte do quadro de funcionários do jornal e representa áreas de atuação como, por exemplo, a médica, a jurídica, a política, a sindical entre outras. São formadores de opinião, homens reconhecidos por sua competência social ou profissional. Citam, como exemplo, Antônio Ermírio de Moraes, José Sarney e Ives Gandra da Silva Martins.

Esclarecem que a intenção de um artigo de opinião não é a divulgação de um fato, mas uma reação-resposta ao que já se disse sobre ele. Os articulistas tomam aquilo que já foi dito como objeto de crítica, de questionamento ou de concordância. Emitem seu ponto de vista e incorporam ao seu discurso a fala de outras pessoas que já se pronunciaram sobre o tema, valorizando a opinião delas ou desvalorizando-a, dialogando com elas.

Além dessas informações, as autoras reforçam o fato de que o tom do artigo de opinião é o convencimento, seu objetivo é convencer ou persuadir ${ }^{35}$ o leitor,

\footnotetext{
${ }^{35}$ Neste momento, as autoras utilizam, além do termo convencer, o termo persuadir.
} 
tentando engajá-lo na posição de aliado, antecipando as possíveis objeções, levando-as em conta e, como articulistas, representar setores sociais, posicionandose. Essa situação de produção é revelada por marcas lingüísticas que demonstram a posição do articulista ["penso que", "do nosso ponto de vista"]; fundamentam os argumentos ["pois", "porque"]; trazem as diferentes vozes ["alguns dizem que", "as pesquisas apontam"] e introduzem a conclusão ["portanto", "logo"].

Essas considerações sugerem a necessidade de buscar suporte teórico para nossas análises, dentre outros, nos trabalhos de Koch (2004a), Authier-Revuz (1990), Bakhtin (2003) e Perelman \& Olbrechts-Tyteca (2005) e, no que se refere ao ensino por meio do trabalho com gêneros, Bronckart (2003) e a Dolz e Schneuwly (2004). Por essa razão, apresentamos a síntese desses autores na primeira parte.

Finalizando, as autoras afirmam que as oficinas propostas objetivam desenvolver a capacidade de argumentação dos alunos, aproximar os textos produzidos dos genuínos artigos publicados em jornais e revistas e ampliar o domínio sobre a linguagem escrita. Para que eles "mergulhem no gênero" e "peguem o tom" [aspas das autoras], textos extraídos de jornais e revistas, como também textos produzidos pelos alunos vencedores da etapa 2002, são utilizados para leitura e análise. Sendo assim, a leitura é o ponto de partida para o conhecimento do gênero, etapa preparatória para a produção que virá na seqüência.

\section{f. Oficinas}


Transcreveremos, abaixo, o quadro-síntese das oficinas que dá ao professor uma visão geral do caminho a ser percorrido. Trata-se de uma seqüência didática ${ }^{36}$ que se desenvolve ao longo de algumas aulas, partindo da criação de uma situação de produção e de atividades de leitura para chegar à produção textual. Logo após, será feita uma descrição de cada uma das oficinas - ou etapas da seqüência didática -, dada sua importância para o desenvolvimento das habilidades de competência de escrita programadas pelo concurso que devem transparecer nas produções do corpus.

\section{Quadro-síntese das oficinas}

\begin{tabular}{|l|l|}
\hline Oficina & Objetivo \\
\hline $\begin{array}{l}\text { orienta para a escrita do gênero } \\
2 \quad \text { Identificando }{ }^{37} \text { questões polêmicas } \\
\text { sem as quais não há artigo de opinião }\end{array}$ & $\begin{array}{l}\text { Levantar, junto com os alunos, questões } \\
\text { polêmicas que circulam em sua } \\
\text { comunidade. }\end{array}$ \\
\hline 3 Lendo artigos de opinião & $\begin{array}{l}\text { Colocar o aluno, por meio de um jogo } \\
\text { simbólico, no lugar do articulista. }\end{array}$ \\
\hline $\begin{array}{l}\text { Levar os alunos a ter um contato inicial } \\
\text { com o gênero, identificando questões } \\
\text { polêmicas. }\end{array}$ \\
\hline
\end{tabular}

\footnotetext{
${ }^{36}$ A expressão "seqüência didática" é utilizada pelos autores Adam, A., além de Dolz e Schneuwly (2004). Convém observar que as autoras utilizam, neste fascículo do Prêmio 2004, a expressão "sequiência de atividades". Já, no material impresso do Prêmio 2006, as autoras utilizam "sequiência didática".

${ }^{37}$ Notamos grande quantidade de gerúndios nos títulos das oficinas e das atividades. Com aspecto durativo, essa forma nominal do verbo exprime o fato em desenvolvimento, enquanto ele ocorre, em geral acompanhando outra forma verbal não nominal, expressa na ação principal. O gerúndio dos títulos, no entanto, aparece solto, isolado, repetidas vezes. Soa como um anglicismo. Em vez dele, seria preferível o infinitivo - outra forma nominal do verbo - que nomeia e indica o processo verbal, exprimindo a idéia da ação e aproximando-se, também, do substantivo, outra categoria adequada para títulos expressos em frases nominais, sem verbo. (CUNHA, C.; CINTRA, L., 2001e BECHARA, 2004). Com base em gramáticos, sugerimos trocar o gerúndio dos títulos por infinitivo ou substantivo. Por exemplo: Identificação [...]; Leitura [...] ; Reconhecimento e articulação [...]; Análise [...]; Ensaio [...]; Aprimoramento [...] e Busca de [...] .
} 


\begin{tabular}{|c|c|}
\hline Oficina & Objetivo \\
\hline 4 Primeira produção & $\begin{array}{l}\text { Diagnosticar o conhecimento do aluno do } \\
\text { gênero para melhor intervir em seu } \\
\text { processo de aprendizagem. }\end{array}$ \\
\hline $\begin{array}{l}5 \text { Reconhecendo e articulando posições, } \\
\text { argumentos e conclusões }\end{array}$ & $\begin{array}{l}\text { Levar o aluno a reconhecer alguns } \\
\text { elementos do gênero. }\end{array}$ \\
\hline 6 Pesquisa de opinião & $\begin{array}{l}\text { Possibilitar a inserção de opiniões de } \\
\text { pessoas da comunidade na produção } \\
\text { escrita. }\end{array}$ \\
\hline 7 Analisando um artigo de opinião & $\begin{array}{l}\text { Perceber a forma de tecer um artigo de } \\
\text { opinião. }\end{array}$ \\
\hline $\begin{array}{l}8 \text { Ensaiando a produção de um artigo de } \\
\text { opinião }\end{array}$ & $\begin{array}{l}\text { Utilizar o resultado das oficinas } \\
\text { anteriores para a elaboração de uma } \\
\text { escrita coletiva, mediada pelo professor. }\end{array}$ \\
\hline 9 Aprimorando o texto & $\begin{array}{l}\text { Distinguir marcas de oralidade próprias } \\
\text { da escrita. }\end{array}$ \\
\hline 10 Buscando informações & $\begin{array}{l}\text { Buscar dados sobre o tema escolhido } \\
\text { para sustentar a opinião. }\end{array}$ \\
\hline 11 Produção final & $\begin{array}{l}\text { Produzir a escrita individual que } \\
\text { participará da seleção para o concurso. }\end{array}$ \\
\hline
\end{tabular}




\section{Oficina 1 - Situação de produção}

Orientam que, primeiramente, é fundamental explicar aos alunos as condições que regem o Prêmio Escrevendo o Futuro e incentivá-los a participar, principalmente pela recompensa de aprender a escrever com qualidade e, assim, poder participar melhor da vida da comunidade, além dos possíveis prêmios.

A proposta coincide com a de Dolz e Schneuwly (2004): para a produção de qualquer gênero de texto, é preciso criar uma situação de produção, fictícia ou real. Para essa atividade, a proposta é que, em sala de aula, seja criado um ambiente semelhante ao de uma redação de jornal. O professor seria o editor que convida um conhecedor do assunto debatido para publicar um artigo na seção "Opinião". Os alunos assumem a posição desse articulista convidado a escrever sobre uma questão polêmica que esteja mobilizando a comunidade onde vivem. Deverão assumir uma posição e argumentar a favor dessa posição, buscando convencer os leitores de que seu ponto de vista é o melhor, como articulistas devem conhecer bem o assunto para construir seus argumentos. Deve ser criado um nome bem sugestivo para o jornal fictício.

O item conclusivo, "Dica para o professor", afirma que há momentos, no trabalho escolar, em que é preciso simular uma situação de produção, mas que também há oportunidades reais em que se pode solicitar uma produção escrita, como cartazes para a festa junina da escola, carta ao prefeito fazendo um pedido, uma biografia de uma personalidade da cidade etc. 


\section{Oficina 2 - Identificando questões polêmicas}

Esta oficina é composta por quatro atividades:

\section{Envolvendo os alunos e colocando-os no papel de articulista}

Com o objetivo de envolver os alunos e colocá-los na posição do articulista, pedem que o professor leve para a classe assuntos ventilados na televisão ou no rádio, de preferência que afetem o contexto em que vivem. Finalizam, indicando sugestões de temas.

\section{Escolhendo uma questão e realizando o debate}

Propõem a organização de um debate oral, tendo o professor como mediador cuja função é estimular a discussão, de forma imparcial, entre dois grupos, um a favor e outro contra determinado tema. O público será composto pelos demais alunos. Cada grupo deverá encontrar argumentos para fundamentar sua posição e o público pode elaborar perguntas. Após algum tempo de debate, propõe-se a troca de papéis. Isso permitirá que o aluno se coloque no lugar do outro e amplie sua visão sobre a questão polêmica que estiver sendo discutida.

O debate, retomado da proposta de Dolz e Schneuwly (2004), é um bom exercício para envolver os alunos, permite que criem argumentos coerentes com o ponto de vista assumido e ouçam as justificativas da posição contrária, criando oportunidade para que possam rever a própria posição ou reafirmá-la. 


\section{Resgatando situações vividas pelos alunos}

Formar uma roda de conversa e fazer perguntas aos alunos, incentivando-os a trazer suas experiências e seus conhecimentos sobre alguma questão polêmica que vivenciaram e que afetou a vida do lugar onde vivem. Se necessário, apresentar notícias presentes em jornais e revistas ou apresentar alguns temas abordados pelos alunos semifinalistas do concurso anterior. É fundamental que eles encontrem assuntos que sintam como seus e nos quais estejam implicados, pois assim, aquilo que disserem terá mais força, não soará como um conjunto de palavras vazias.

\section{Levantando questões que causam maior mobilização}

Fazer um quadro com as questões polêmicas que geraram mobilização, na etapa anterior, anotar as posições tomadas e os primeiros argumentos surgidos. $\mathrm{O}$ quadro, transcrito parcialmente abaixo, será utilizado em outras ocasiões, no caso de ser necessário organizar mais pesquisas sobre o assunto ou, até mesmo, outro debate, por isso deverá ficar em um local visível.

\section{Questão1}

Posição favorável - Argumentos

a)

b)

Posição contrária - Argumentos

a)

b)

Questão 2 [...] 


\section{Oficina 3 - Lendo artigos de opinião e reconhecendo questões polêmicas}

Esta oficina é composta por três atividades:

\section{Lendo artigos produzidos por alunos}

Os alunos deverão ler os dois artigos de opinião que acompanham essa atividade e que devem ser copiados numa folha de papel ou na lousa. Esses textos ${ }^{38}$ foram produzidos por alunos semifinalistas da primeira edição do concurso e neles serão identificadas as questões polêmicas presentes. Sugerem que o professor, para ajudá-los, faça perguntas e dê pistas.

\section{Familiarizando o aluno com artigos de opinião publicados em jornal}

As autoras orientam que, para que os alunos se capacitem a escrever artigos de opinião, é necessário ter contato com esse gênero. $O$ artigo escolhido foi publicado no jornal Folha de São Paulo, na seção Opinião, no dia 24 de março. Escrito por Antônio Ermírio de Moraes, "Depois da água, por que não o ar?”39. Consideram que o texto trata de uma questão polêmica, fundamental para a sobrevivência da humanidade e, "mesmo que não seja do interesse imediato de seus alunos, seria importante que eles pensassem sobre ela". Sete questões, que deverão ser respondidas pelos alunos, acompanham a atividade.

Após algumas reflexões sobre a escolha desse texto, faremos algumas considerações. A primeira é sobre o fato de as autoras afirmarem que o tema não é

\footnotetext{
${ }^{38}$ Os textos encontram-se em anexo.

${ }^{39} \mathrm{Na}$ edição do Prêmio Escrevendo o Futuro - 2006, esse artigo foi substituído pelo texto Sou contra a redução da maioridade penal de Renato Roseno que, na edição 2004, acompanha o material de apoio.
} 
de interesse dos alunos, então perguntamos: por que apresentá-lo, por que não buscar algo que seja de interesse deles? Conforme Louzada (1996, p. 138) "[...] quanto mais estreitas [...] forem as relações entre leitura e escrita, mais efeitos positivos podem trazer para o desenvolvimento das competências de leitura e de escrita dos alunos”. Com relação ao entendimento do texto, faz-se necessário avaliar fatores que interferem nesse processo, neste caso, a faixa etária dos alunos, seus esquemas cognitivos, sua bagagem cultural e seu conhecimento dos elementos lingüísticos. Quanto a isso cabe recuperar as colocações de Koch (2006, p. 28): "em nosso dia-a-dia, depararmo-nos com inúmeros textos [...] cuja produção é 'orientada' para um determinado tipo de leitor [um público específico], o que, aliás, vem evidenciar o princípio interacional constitutivo do texto [...]". Consideramos significativo para a aprendizagem apresentar textos com certo grau de informatividade, pois sabemos que "[...] a compreensão não requer que os conhecimentos do texto e do leitor coincidam, mas que possam interagir dinamicamente" (Alliende \& Condemarín, 2002, p126-7, apud Koch, 2006, p. 37).

Outro aspecto é quanto ao tamanho do artigo. As instruções sugerem aos professores que o reproduzam na lousa ou tirem cópias para que os alunos possam acompanhar a leitura. As duas opções são questionáveis: a primeira, pelo fato de que copiá-lo exigiria das crianças de $4^{a}$ ou 5 séries uma custosa atividade e um longo tempo; a segunda, porque talvez se torne complicado providenciar as cópias necessárias. Este concurso, como já afirmamos, abrange as mais diversas regiões do país. Devemos esclarecer que as autoras sempre incentivam os professores a superar os obstáculos, inclusive, relatando exemplos de alguns profissionais que o fizeram, como no caso da professora de um aluno cujo texto foi um dos finalistas da última edição. Em sua cidade não havia banca de jornal, ela diz o que fez para 
conseguir o jornal de que precisava. Mas lembramos: o sucesso do projeto tem relação direta com a viabilidade do projeto.

\section{Fazendo circular artigos de opinião}

O professor fará circular, entre os alunos, outros artigos de opinião publicados em jornais, disponíveis no final do volume do caderno; se preferir, acrescentará textos escolhidos por ele ou solicitará aos alunos que formem equipes para que cada uma consiga um jornal.

Esses artigos sofrerão o mesmo processo de análise do artigo da Folha de São Paulo, sendo, então, socializados pelas equipes.

\section{Oficina 4 - Primeira produção}

As autoras esclarecem que os textos produzidos, nesta etapa, servirão de diagnóstico para o professor, no sentido de fazer as intervenções necessárias na estrutura do artigo, verificando se ele traz uma questão polêmica; localiza o leitor em relação a essa questão, deixa clara a posição do autor; apresenta o pensamento dos opositores; traz argumentos convincentes; apresenta problemas graves de ortografia ou gramática e outras dificuldades. Essas produções iniciais devem ser guardadas, pois serão comparadas com a produção final e enviadas para o concurso.

Para os alunos, servirão para avaliar o próprio desempenho. O professor deve ajudá-los a verificar os problemas, explicando-lhes que os adultos escrevem seguidas vezes o mesmo texto, antes de obter uma forma satisfatória. Além disso, 
deve incentivá-los a participar das próximas oficinas, para aperfeiçoar a escrita do texto e ter mais chances de ganhar os prêmios. Novamente, os organizadores utilizam o prêmio como motivação para incentivar a participação dos alunos. Esse procedimento foi utilizado na oficina 1 , quando da apresentação do concurso. Avaliamos de forma positiva essa estratégia, pois o desejo de vencer auxiliará professores e alunos a superar as dificuldades enfrentadas ao longo da seqüência didática.

\section{Oficina 5 - Reconhecendo e articulando posições, argumentos e conclusões}

Essa oficina é composta por 5 atividades:

\section{Reconhecendo posições, argumentos e conclusões}

O objetivo é exercitar o conhecimento desses elementos, nos fragmentos dos artigos de opinião apresentados, dois textos de alunos semifinalistas do concurso anterior. Propõem que se peça aos alunos, por meio de perguntas, que identifiquem a questão polêmica discutida, as palavras que marcam a tomada de posição, a palavra que indica a introdução de argumentos e os próprios argumentos.

\section{Reconhecendo argumentos favoráveis e contrários}

O professor deve iniciar uma discussão sobre lição de casa e perguntar o que cada um pensa a respeito do assunto. Em seguida, deve escrever, na lousa, os argumentos propostos pelo material, dividir os alunos em duplas e lançar o desafio: 
descobrir quem poderia ser autor dos argumentos a favor e contra a lição de casa e quais palavras ou expressões forneceram pistas para fazer a descoberta.

\section{Colocando-se no ponto de vista do outro}

Esta atividade tem o objetivo de levar os alunos a se colocar no ponto de vista do outro e a antecipar as possíveis alegações de seus opositores, para depois refutá-las. A situação proposta é a posição diferente entre pais e filhos sobre determinada questão. Os papéis representados pelos alunos, de pai e de filho, deverão ser trocados, as duplas deverão socializar os argumentos utilizados e depois registrá-los no caderno.

\section{Conhecendo os elementos articuladores do artigo de opinião}

As autoras afirmam que todas as atividades propostas, até então, objetivaram levantar alguns aspectos do texto de opinião, mas que, isolados, não formam um texto. É preciso organizá-los e ligá-los e encaminhar o texto para um fechamento, de modo que ele tenha uma conclusão satisfatória. Explicam que todo gênero possui elementos articuladores que permitem a retomada de algo comentado anteriormente e o acréscimo de novas idéias.

Propõem que o professor copie, em tarjetas, as frases sugeridas e as corte nas linhas pontilhadas. Cada grupo terá o desafio de montá-las adequadamente. As expressões articuladoras propostas para esse trabalho são: "porque; pois; visto que; portanto; então; logo e por isso". 
Nota-se, aqui, uma atividade voltada para o emprego dos operadores argumentativos, conforme propõe Koch (2004a).

\section{Utilizando expressões articuladoras}

Com o objetivo de fazer com que os alunos compreendam o valor da negociação, percebendo que ela é fundamental para o exercício da democracia, as autoras pedem que o professor polemize a seguinte situação: os alunos de uma escola podem usar a quadra de esportes no final de semana. No entanto, como fizeram muita bagunça, a diretora proibiu seu uso.

Logo após, sugerem que o professor promova a reflexão do grupo por meio de perguntas sobre o assunto e proponha um jogo dramático, sendo que cada aluno desempenharia um papel.

O próximo passo será convidar os alunos a completar uma carta para a diretora da escola em questão. O desafio consiste em preencher as lacunas com expressões articuladoras que deverão ser transcritas em uma tabela, numa folha de papel, e afixada em local visível.

Para esta atividade, além do modelo da carta, o professor é subsidiado com exemplos de expressões articuladoras que serão transcritas, a seguir, por sua importância para o concurso, pelo fato de serem elementos avaliados pela Comissão Julgadora e, sobretudo, por serem fundamentais na construção do texto argumentativo, conforme Koch (2004a). Por esses motivos, faremos um levantamento da ocorrência desses elementos, em nossa análise da produção discente. 
As expressões apresentadas são aquelas que:

a) Anunciam a posição do autor: do meu ponto de vista; na minha opinião; pensamos que; pessoalmente.

b) Indicam certeza ou probabilidade: sem dúvida; está claro que; com certeza; é indiscutível; me parece que; provavelmente.

c) Introduzem argumentos: porque; pois; mas.

d) Introduzem a conclusão: então; conseqüentemente; por conseguinte; assim.

e) Organizam a articulação do texto como um todo: por um lado ... por outro lado; primeiramente, em segundo lugar, para finalizar.

\section{Oficina 6 - Pesquisa de opinião}

Esta oficina é composta por 2 atividades:

\section{Fazendo uma pesquisa de opinião com a comunidade}

Os objetivos desta atividade são: reconhecer marcas que identificam opiniões como, por exemplo, "sou a favor porque ...", "na minha opinião ..." ; identificar o que as pessoas dizem para sustentar sua posição; considerar opiniões contra e a favor e trazer as vozes dos entrevistados.

A proposta é que o quadro elaborado, na atividade da oficina 2, seja retomado e que sejam escolhidas três ou quatro questões polêmicas que envolvam a classe. Organizados em grupos, os alunos deverão entrevistar pelo menos 5 pessoas da comunidade, fazendo uma pesquisa de opinião. Os argumentos serão anotados em 
fichas cujos modelos são sugeridos pelos organizadores. Posteriormente, serão montados quadros com os resultados das pesquisas de opinião.

Convém notar que, em um dos quadros sugeridos, são utilizados os operadores pois, porque, visto que. Reafirmamos que tanto as expressões tratadas na oficina anterior como esses operadores serão considerados, em nosso trabalho, quando da análise do corpus.

\section{Identificando exemplos e pesquisas usados como argumentos}

Esta atividade objetiva que os alunos: reconheçam a presença de exemplos utilizados como argumentos pelos entrevistados; identifiquem dados de pesquisas, empregados por eles para fundamentar sua posição e derrubar o argumento de seus opositores e, por último, encontrar, em alguns argumentos, comentários feitos por autoridades no assunto, citando, como exemplo, as seguintes construções: $O$ senhor fulano, que é vereador, disse que... .

Antes, porém, a classe é convidada a exercitar essa atitude, construindo exemplos para opiniões sugeridas pelo material.

Um dos resultados obtidos por essa atividade é um elevado índice de polifonia nos textos semifinalistas, o que nos levou a buscar suporte teórico nos estudos de Bakhtin (2003) e Authier-Revuz (1990). Pela análise, fomos ainda levados a refletir sobre a presença de termos que não são próprios na linguagem de crianças na faixa etária entre 10 e 11 anos e que foram encontrados nos textos. 


\section{Oficina 7 - Analisando um artigo de opinião}

Nesta oficina, são propostas 2 atividades: "Lendo o texto de Thais" e "Identificando diferentes vozes".

O objetivo, ao analisar o texto de Thais Gysanne, semifinalista do concurso 2002, é fazer com que os alunos percebam como ela construiu seu texto, seguindo o exemplo dos artigos publicados nos jornais, ao incorporar diferentes vozes que circulam em sua comunidade sobre a polêmica de que trata. Para auxiliar o professor, o material apresenta perguntas que serão respondidas pelos alunos. Elas visam a dar relevo aos seguintes aspectos, pertinentes a esse gênero de texto: o autor situa o leitor sobre a questão polêmica tratada; toma uma posição em relação ao assunto controverso; apresenta argumentos que justificam e sustentam a própria posição; antecipa e contesta os argumentos dos oponentes, desvalorizando-os; estabelece a ligação entre as partes do texto; conclui o texto utilizando expressão conclusiva, reafirmando a própria posição.

\section{Oficina 8 - Ensaiando a produção de um artigo de opinião}

A atividade desta oficina é a construção coletiva de um artigo de opinião, a partir de uma situação proposta, sobre a qual os alunos deverão tomar uma posição, levantar argumentos que favoreçam a posição tomada e encontrar um possível contra-argumento do oponente. O professor será o redator da escrita coletiva, auxiliando os alunos a organizar os argumentos, a empregar expressões que introduzem diferentes vozes, a dar um fechamento ao texto e a reafirmar a posição tomada. Além disso, caberá a ele ajudá-los a fazer a pontuação, a abertura de 
parágrafos e o uso de pronomes e sinônimos, para evitar a repetição de palavras. Esse texto será copiado pelos alunos, devendo, também, ficar exposto para servir de referência para a produção individual final.

\section{Oficina 9 - Aprimorando o texto}

As atividades que compõem esta oficina são:

\section{Lendo e analisando mais um texto de opinião}

Nesta leitura, os alunos serão orientados a refletir sobre os elementos articuladores do texto para evitar a repetição de palavras, isto é, o emprego de pronomes e palavras do mesmo campo lexical das que já foram utilizadas pelo autor (ações que estabelecem a coesão textual) e a substituição de conectivos utilizados na linguagem oral pela pontuação.

\section{Aprimorando um texto}

Fazendo o papel de revisores do texto, os alunos reescreverão o texto oferecido pelo material, evitando repetições de palavras, utilizando pontuação correta, abrindo parágrafos e eliminando expressões próprias da linguagem oral como "aí" e "então". 


\section{Oficina 10 - Buscando informações}

Argumentos firmes e consistentes são construídos por meio da busca de informações sobre o tema tratado. Esse domínio de dados quantitativos, históricos e geográficos, segundo orientam as autoras, contribui para a sustentação da argumentação. Para tanto, a proposta de trabalho, nesta atividade, é a realização de pesquisas, pelos alunos, em jornais, livros, internet, vídeos informativos complementados por entrevistas com especialistas conhecedores do assunto escolhido, para a produção de um artigo de opinião.

\section{Oficina 11 - Produção final}

Com o título Chegou a hora tão esperada!!!, nesta etapa final, as autoras afirmam que o entusiasmo do professor pela tarefa contaminará a todos, o que será demonstrado pela sua mobilização e pelo auxílio dado aos alunos na própria escrita. Sugerem que ele retome, anotando na lousa ou em uma folha de papel grande, a situação de produção proposta pelo projeto e as expressões características de um artigo de opinião. Orientam que, durante a produção do texto, sejam escritos corretamente, no quadro, os problemas relativos à ortografia que surgirem.

A palavra "entusiasmo" é muito utilizada pelas autoras. Desde o início, afirmam que o entusiasmo do professor contaminará os alunos, em outro momento desejam que todos se empolguem e trabalhem animados. Essas ações de incentivo remetem-nos a Schneuwly e Dolz (2004, p. 273), ao analisarem O lugar do 
professor e o sentido das coisas: "na seqüência didática, o papel do professor é primordial, em todos os momentos".

O roteiro, transcrito, a seguir, deverá ser copiado, na lousa, após a atividade de produção, e servirá de orientação para o aluno analisar seu texto, antes de passá-lo a limpo. O professor fará a revisão final antes de o texto ser redigido em sua versão definitiva e passado a limpo no papel especial destinado ao produto final.

\section{Correção}

1. Colocou o leitor a par da questão polêmica?

2. Tomou uma posição?

3. Introduziu-a com expressões como: penso que, na minha opinião?

4. Levou em consideração os pontos de vista dos adversários para construir seus argumentos? Exemplo: Muitas pessoas são favoráveis à construção de uma fonte, afirmando que ela embelezaria a cidade, porém ... .

5. Usou expressões que introduzem os argumentos, como pois, porque?

6. Utilizou argumentos de autoridade e/ ou exemplos?

7. Usou expressões para introduzir a conclusão? Exemplos: então, assim, portanto.

8. Concluiu o texto reforçando sua posição?

9. Verificou se a pontuação está correta?

10. Lembrou-se de iniciar com letra maiúscula os nomes próprios, início de parágrafos e após o ponto final?

11. Corrigiu os erros de ortografia?

12. Escreveu com letra legível para que todos possam entender? 


\section{Palavras (quase) finais}

Em linguagem informal, em tom de conversa entre amigos, as autoras encerram o projeto, afirmando que "os textos escritos" conversam entre si, da mesma forma como elas, que produziram o material, conversaram com os professores que "puseram a mão na massa" ${ }^{40}$ e também com outras pessoas que discutem ou discutiram a escrita e seu ensino. Apresentam uma relação de referências bibliográficas e sugerem que os professores "conversem" com alguns autores como Bakhtin, M. (1992), Rojo, R. (2000), Schneuwly, B. (1994) entre outros, indicados na bibliografia.

\section{Textos indicados}

Após as referências bibliográficas, as autoras finalizam o material com cinco textos de opinião ${ }^{41}$, cujos títulos são: Sou contra a redução da maioridade penal de Renato Roseno; Trabalho infantil consome o futuro de muitas crianças de Jô Azevedo; $A$ droga que é uma droga de Vera Meire Bestene; Meio ambiente $X$ direitos humanos de Sidney Grippi, Direito ao lazer $^{42}$ de Anna Helena Altenfelder e o texto vencedor do Prêmio 2002 "Benjamim sem máscara" de Ronilson da Silva Procópio. Esses textos têm o objetivo de complementar o trabalho do professor.

\footnotetext{
${ }^{40}$ A expressão empregada pelas autoras é "pondo a mão na massa".

${ }^{41}$ Os textos encontram-se em anexo.

${ }^{42}$ Um dos textos semifinalistas analisados em nosso corpus ( 201) traz como questão polêmica a necessidade de construção de áreas de lazer no seu bairro.
} 


\subsection{Considerações sobre o material do Prêmio}

Como vimos, as oficinas foram elaboradas para permitir ao aluno o acesso ao gênero discursivo "artigo de opinião", iniciando pela criação de uma situação de produção, pela leitura desse gênero e pela identificação das características e marcas lingüísticas que lhe são próprias. São propostos exercícios que permitem o desenvolvimento das habilidades necessárias para esse fim como: i) tomada de posição por parte do articulista diante da situação problema - oficina 8; ii) criação de uma situação de produção - oficina 2; iii) utilização de operadores argumentativos e marcadores discursivos - oficina 5; iv) identificação das diferentes vozes presentes no artigo de opinião - oficina $7 ;$ v) situações que permitam exercitar e fundamentar opiniões, assim como refutar opiniões contrárias - oficina 6; vi) atividades de pesquisa sobre o tema polêmico, na comunidade em que vivem, com o objetivo de munir o aluno de informações - oficina 6 -; vii) levantamento de dados, observações e análises sobre o assunto - oficina 10 .

Gostaríamos de refletir sobre a importância da atividade proposta pela oficina 10, considerando as afirmações de Louzada (1996). Segundo ela, "[...] a eficácia de todo discurso também se prende à quantidade e qualidade de informações, dados, observações e análises empreendidas pelo locutor, obtidas através de experiências concretas de vida e da leitura de textos e do mundo" (Ibid., p. 24). Trata-se da formação de repertório, sem o qual não há possibilidade de se ter idéias nem sequer de assumir posição a respeito de qualquer assunto. Essas afirmações são sustentadas pelas teorias de Vygotsky sobre desenvolvimento: todos os indivíduos podem aprender mais, se estimulados por outros, sendo assim, "[...] o homem se 
constitui na relação social, na relação com o outro "(OLIVEIRA apud LOUZADA, 1996, p. 35).

Considerando as propostas de atividades organizadas pelas oficinas, percebe-se, no material escrito, a intenção de estabelecer a interação e o estímulo de que fala Vygotsky, além de buscar apoio no trabalho dos autores Joaquim Dolz e Bernard Schneuwly, que constam da Referência Bibliográfica do Prêmio. Cabe esclarecer que nos limitamos ao material impresso, já que não houve acompanhamento da aplicação das oficinas nas escolas. O objetivo do trabalho é a apropriação de um novo instrumento, o artigo de opinião, que é um gênero secundário que se distancia bastante dos gêneros primários, por isso demanda um trabalho minucioso de preparação e acompanhamento em sua leitura e produção.

Schneuwly e Dolz (2004), ao tratarem dessa questão, recorrem ao exemplo do uso do MAS, tratado no texto de Michel Fayol, Daniel Gaonac'h e Serge Mouchon "Connecteurs et ponctuation: Comparaison production-compréhension": "o aluno já o domina em situações ou gêneros primários, no qual desempenha um certo papel. Esse instrumento é retomado e reutilizado para construir uma nova função no gênero secundário, que poderíamos chamar de mudança de perspectiva no texto [...]". Acrescentam que o antigo instrumento, pelo seu novo uso, reveste-se de novas significações, ao mesmo tempo em que se constroem outros instrumentos para essa nova função, outros meios lingüísticos [...]” (Ibid., p. 34).

Outro aspecto que merece nossa atenção é a viabilidade das atividades propostas nas oficinas. Constatamos que as que apresentam textos para serem passados, no lousa, demandam tempo gasto pelos alunos em copiá-los. Não que a cópia não traga algum benefício para a melhoria da escrita, mas porque não é esse o foco do projeto. Em segundo lugar, Schneuwly e Dolz (2004, p. 266), autores cujos 
estudos serviram de base para desenvolver a seqüência de atividades do concurso, consideram que o trabalho deve ser organizado "[...] de tal forma que uma seqüência não exceda, em nenhum caso, 15 aulas “(lbid., p. 227).

Para analisarmos esse aspecto, fizemos uma estimativa do tempo gasto em cada atividade, considerando-se aulas de 50 minutos e nossa experiência com crianças dessas séries, tanto em escolas da rede pública como da rede particular de ensino.

- Oficina 1 - Situação de produção: 1 aula.

- Oficina 2 - Identificando questões polêmicas:

1. Envolvendo os alunos e colocando-os no papel de articulista: 1 aula;

2. Escolhendo uma questão e realizando o debate: 2 aulas - uma para formar os grupos e elaboração dos argumentos e uma para o debate;

3. Resgatando situações vividas pelos alunos: 1 aula;

4. Levantando questões que causam maior mobilização: 1 aula.

- Oficina 3 - Lendo artigos de opinião e reconhecendo questões polêmicas:

1. Lendo artigos produzidos por alunos: 2 aulas - uma passar na lousa e uma para discutir;

2. Familiarizando o aluno com artigos de opinião publicados em jornal: 3 aulas - uma ou duas aulas para copiar e ler e uma aula para responder às questões;

3. Fazendo circular artigos de opinião: 2 aulas - uma para leitura e respostas às perguntas e uma para socialização; 
- Oficina 4 - Primeira produção: 2 aulas - uma para produção e uma aula para auto-avaliação.

- Oficina 5 - Reconhecendo e articulando posições, argumentos e conclusões:

1. Reconhecendo posições, argumentos e conclusões: 2 aulas - uma aula para responder e uma aula para socialização e discussão;

2. Reconhecendo argumentos favoráveis e contrários: 1 aula;

3. Colocando-se no ponto de vista do outro: 1 aula;

4. Conhecendo os elementos articuladores do artigo de opinião: 1 aula;

5. Utilizando ${ }^{43}$ expressões articuladoras: 3 aulas - uma aula para a dramatização, uma aula para a cópia da carta e uma preenchimento e discussão.

- Oficina 6 - Pesquisa de opinião:

1. Fazendo uma pesquisa de opinião com a comunidade: 3 aulas - uma aula para encaminhar a pesquisa, uma aula para completar os quadros e uma para socializar os dados;

2. Identificando exemplos e pesquisas usados como argumentos: 3 aulas duas aulas para copiar e construir exemplos e uma aula para analisar as entrevistas.

- Oficina 7 - Analisando um artigo de opinião: 3 aulas - uma aula para leitura e reflexão, uma aula para responder às questões e uma para socializar as respostas.

\footnotetext{
${ }^{43} \mathrm{O}$ emprego exagerado do gerúndio fica mais evidente quando títulos e subtítulos são colocados juntos.
} 
- Oficina 8 - Ensaiando a produção de um artigo de opinião: 2 aulas.

- Oficina 9 - Aprimorando o texto:

1. Lendo e analisando mais um texto de opinião: 2 aulas - uma aula para copiar e uma aula para análise;

2. Aprimorando um texto: 2 aulas - uma aula para copiar e uma aula para reescrever o texto.

- Oficina 10 - Buscando informações: 2 aulas.

- Oficina 11 - Produção final: 4 aulas - uma aula para anotações e discussão geral, duas para a produção do texto e uma aula para escrever o roteiro na lousa e orientar os alunos.

Não foram contabilizadas aulas com atividades de gramática (ortografia, concordância, regência, construção do discurso indireto, entre outras), necessárias para sanar dúvidas que são próprias do processo de escrita e reescrita, sugeridas pelas autoras, mas não previstas pelas oficinas, provavelmente, porque cada turma apresentará necessidades diferenciadas. Sabemos que o prazo previsto entre a inscrição no concurso e a entrega do texto escolhido pela comissão julgadora da escola é de vários meses, mas essas constatações nos levam a considerar um aspecto verificado por Schneuwly e Dolz (2004, p. 267), na aplicação de seqüências didáticas, que é o cansaço dos alunos e do professor.

Esse aspecto, duração da aplicação, nos faz refletir sobre o fato de o Prêmio Escrevendo o Futuro ter a intenção de instrumentalizar professores de escolas sediadas em regiões carentes, com pouca disponibilidade de publicações e professores sem cursos de capacitação que, ao ensinar, também aprendem, sendo 
um projeto que visa à aquisição da escrita e que deve ser desenvolvido paulatinamente. Nesse caso, acreditamos que o Prêmio atinja seu objetivo, não pelas cópias xerocopiadas necessárias para alguns textos sem considerar as condições sócio-econômicas da região e o cansaço dos alunos e do professor, o que precisa ser repensado, mas pela linguagem utilizada pelas autoras, pela clareza nas orientações e pelo tom de conversa informal. Todos esses elementos dão segurança aos professores que se sentem capazes e preparados para, em anos seguintes, auxiliar outros alunos nas atividades de escrita, tornando-se, dessa forma, multiplicadores.

Devemos ressaltar a importância das oficinas que viabilizaram a ampliação do repertório dos alunos envolvidos no concurso. Tanto as pesquisas quanto as entrevistas dão segurança aos articulistas, alunos redatores, para buscar, por meio de estratégias argumentativas, defender seu ponto de vista e refutar opiniões contrárias.

Outro aspecto que merece nossa atenção é a adequação dos textos escolhidos, como material de apoio, à faixa etária das crianças envolvidas no Prêmio. Frases como "Vivemos em um sistema socioeconômico historicamente desigual e violento [...]", "[...] temos que fazer opções mais eficientes e condizentes com os valores que defendemos." (Sou contra a redução da maioridade penal de Renato Roseno) ou "O segundo problema é que os recursos provenientes dessa taxa serão arrecadados para um fundo federal, para depois serem redistribuídos aos municípios." (Depois da água, por que não o ar? de Antônio Ermírio de Moraes) não são próprios do universo infantil.

No próximo capítulo, ao longo das análises, retomaremos alguns pontos de nossa reflexão sobre o concurso. 


\section{CAPÍTULO III}

TEXTOS SEMIFINALISTAS DO PÓLO SÃO PAULO PREMMIO ESCREVENDO O FUTURO - 2004 


\subsection{Apresentação do Corpus}

Neste capítulo, analisaremos os artigos de opinião que compõem o corpus da nossa pesquisa: os textos semifinalistas do Prêmio Escrevendo o Futuro, do Pólo São Paulo, no ano de 2004, do gênero artigo de opinião. Nosso objetivo, inicialmente, era verificar as estratégias argumentativas utilizadas pelos alunosautores por meio das marcas discursivas presentes no texto. Conforme nossas análises se ampliaram e se aprofundaram, sentimos necessidade de também buscar as marcas da heterogeneidade devido ao elevado índice de polifonia presente nos textos.

Nosso corpus é composto por oito textos que apresentam no cabeçalho: nome da escola e seu CNPJ; nome do professor e seu CPF; nome do aluno, série e sexo; data da produção e gênero do texto. Cada um vem marcado com um número em letra cursiva e com caneta colorida: 9; 32; 71; 76; 89; 128; 130 e 201, que será utilizado para nos referirmos a eles. A numeração das linhas foi feita por nós.

Antes de iniciar as análises, apresentaremos o título de cada texto e a questão polêmica de que tratam:

a) texto 9 : Contra sua vontade - dois animais vivem enjaulados, em um zoológico da cidade, e necessitam de um ambiente maior e mais adequado para viver e poder compartilhar a companhia de outros animais da mesma espécie;

b) texto 32: Santos com ou sem o Museu Pelé? - a permissão para a construção do museu enfrenta problemas burocráticos pelos impasses criados em torno da questão de sua posse ou localização; 
c) texto 71: Pensando no futuro de Amadeu Amaral - questão gerada em torno da aprovação do projeto para a pavimentação da Estrada Vicinal Sebastião Rodrigues Tristão, no município paulista de Marília;

d) texto 76: Segurança para todos - o pedido feito para a instalação de um semáforo, em frente à escola, não é atendido por questões burocráticas ligadas à Secretaria de Transportes do Município de Guarulhos;

e) texto 89: Café na Avenida: certo ou errado? - polêmica gerada pelo fato de o prefeito de Dois Córregos ter permitido que um fazendeiro de café utilizasse uma das principais avenidas da cidade para secar sua colheita;

f) texto 128: Os semáforos em Itaí - trata da necessidade ou não da instalação de semáforos na cidade;

g) texto 130: Com dinheiro não se brinca - a reforma da praça da cidade gerou divisão de opiniões em virtude do valor gasto nesse projeto;

h) texto 201: A construção de áreas de lazer em nosso bairro - polêmica criada pela falta de investimento público em áreas de lazer de bairros pobres, no caso, o Jardim Umuarama (não há referência sobre o nome da cidade).

Esses textos são o produto final resultante das oficinas conduzidas pelos professores, apoiados pelo material elaborado pelos organizadores do projeto Escrevendo o Futuro. Os artigos passaram pelas várias etapas de seleção, portanto, correspondem às exigências feitas pelo critério de avaliação do concurso, já indicadas em tabela no capítulo anterior ${ }^{44}$. Nosso interesse está voltado para a verificação e análise do segundo item que compõe essa tabela: presença de elementos da argumentação: tomada de posição; apresentação de dois ou mais argumentos para convencer o leitor; consideração pelo ponto de vista dos

\footnotetext{
${ }^{44}$ Quando da apresentação do Prêmio Escrevendo o Futuro, indicamos a tabela com os critérios de avaliação do concurso e a respectiva atribuição de pontos para cada item [Capítulo II]. (Conf. p. 88 - 89 )
} 
opositores; conclusão com reforço da tomada de posição; utilização de expressões que introduzam argumentos e evidenciem a posição tomada pelo autor e a conclusão. Conforme afirmamos, respondendo a uma necessidade advinda no decorrer do nosso trabalho, também, a polifonia será analisada, buscando perceber as diferentes vozes que se manifestam no texto.

Além desses aspectos, verificaremos, caso ocorram, outros recursos empregados pelos autores mirins como estratégia argumentativa, mesmo que não tenham sido trabalhados nas oficinas. Como afirma Louzada:

[...] a argumentação, entendida geralmente como prática de linguagem em que um locutor assume a defesa de um certo ponto de vista visando ao convencimento do alocutário, faz parte das condutas lingüísticas das crianças desde tenra idade tanto na sua vida cotidiana como, posteriormente, na escola. Trata-se de uma conduta que pode ser considerada própria ao processo de socialização e de desenvolvimento intelectual da criança (LOUZADA, 1996, p. 110, grifo nosso).

A esse respeito, MOSCA (2004a), em A teoria perelmaniana e a questão da afetividade, complementa:

[...] não é difícil constatar que a argumentação faz parte de todos os atos comunicativos da vida diária de qualquer cidadão, que a exercita de modo bastante intuitivo. No entanto, é também verdade que a argumentação eficaz depende da escolha dos argumentos, da maneira de articulá-los e de os modalizar de forma adequada"(Ibid., p. 132, grifo nosso).

Na tabela inserida nas instruções do Prêmio com os critérios de avaliação a que nos referimos, na página anterior, aparece a seguinte observação: “A avaliação deve considerar, sobretudo, se o texto busca convencer". Durante a exposição dos trabalhos das oficinas, encontramos o termo persuadir somente uma vez, no momento em que as autoras falam sobre o artigo de opinião: "todo esse movimento é feito tendo em vista o leitor, porque é para convencê-lo ou persuadi-lo que os articulistas escrevem". Sabemos que quem deseja convencer, usa a razão e quem 
procura persuadir, a emoção. Esse aspecto nos chama a atenção porque encontramos, nesta fase inicial das análises, algumas estratégias argumentativas utilizadas pelos alunos-produtores que atuam de modo direto sobre a sensibilidade do leitor e que não foram trabalhadas nas oficinas. Continuaremos refletindo sobre essa questão.

O artigo de opinião, por ser um texto que pertence ao agrupamento dos gêneros argumentativos (Cf. DOLZ, J.; SCHNEUWLY, B., 2004, p. 121), trata de questões controversas, a respeito das quais o autor toma uma posição, demonstra e sustenta seu ponto de vista, refuta a opinião do adversário, negocia a tomada de posição e tem não só a intenção de convencer como também de persuadir o leitor. Para tanto, lança mão de técnicas e recursos diversos.

Se a intenção primeira de um produtor de texto argumentativo é provocar ou aumentar a adesão do outro a seu ponto de vista, isso pode ser feito por meio de técnicas discursivas utilizadas de forma consciente ou inconsciente. O manejo de forma consciente é mais suscetível de sucesso, uma vez que a argumentação pode ser estruturada e hierarquizada, de modo a garantir um resultado eficaz, o que é mais difícil de ocorrer, no caso do processo inconsciente (Cf. MOSCA, 2004a, p. 132).

Os produtores dos textos de nosso corpus trabalharam, em sala de aula, com o professor e os colegas, em oficinas propostas pelo projeto, nas quais foram desenvolvidas várias atividades. A finalidade das oficinas foi a de instrumentalizar o aluno, para torná-lo competente no gênero discursivo "artigo de opinião", possibilitando que entrasse em contato com estratégias e procedimentos argumentativos próprios desse gênero. Outra finalidade foi ampliar a competência 
de leitura - mediante a adoção de uma postura crítica diante dos textos apresentados pelo material -, da escrita e da reescrita das próprias produções.

Feitas essas considerações, passamos a indicar os aspectos a serem analisados nas produções discentes.

\subsection{Análise do corpus}

\subsubsection{Ethos pré-discursivo e ethos discursivo: a busca do prestígio}

Consideramos importante tratar do ethos discursivo do articulista. Para Aristóteles, "o ethos constitui praticamente a mais importante das provas" (AMOSSY, 2005, p. 40). Seu prestígio é fundamental para adquirir o respeito do auditório - o pathos - e a comunhão dos espíritos. A conquista desse prestígio se dá, a princípio, pela imagem que se faz do orador, é o ethos pré-discursivo. Oleron (1983, p. 104) afirma que o respeito que se tem pelo orador "[...] faz com que suas palavras sejam mais pertinentes e mais claras. Desde o início, o seu prestígio torna o auditório mais atento". Perelman (2004, p. 75) afirma que uma parte desse prestígio está exposta ao risco, pois da mesma forma "[...] como a personalidade do orador garante a seriedade da argumentação, inversamente, uma argumentação fraca ou desastrada diminui a autoridade do orador". Logo, o prestígio é conquistado, mantido, ampliado ou reduzido, ao longo do discurso, pelo alcance que ele tem, ao discutir as questões que envolvem o tema polêmico, podendo-se afirmar que a palavra faz o orador.

Em momento anterior, no capítulo concernente à contextualização teórica, fizemos reflexões sobre o prestígio do ethos pré-discursivo dos autores dos textos 
analisados em nosso corpus e observamos que a situação de produção criada por meio da representação de papéis, na oficina 1 , deu a esses autores a confiabilidade de que precisavam. A manutenção desse respeito dar-se-ia pela demonstração do conhecimento sobre o assunto, ao longo do texto, pela segurança no posicionamento do autor e pelo reconhecimento e refutação de posições contrárias.

Algumas oficinas, como vimos, tiveram como proposta a construção do conhecimento sobre o assunto do qual trataria o texto: a oficina 6, por exemplo, possibilitou que os alunos fizessem uma pesquisa de opinião junto à população e pessoas envolvidas, por meio de entrevistas; a oficina 10 propunha a pesquisa sobre o tema em livros, jornais, revistas e internet. Tanto as pesquisas como as entrevistas com pessoas da comunidade dão a esse autor as condições necessárias para defender a posição que resolver assumir. Importante salientar que os leitores de um artigo de opinião ${ }^{45}$ têm como esquema de conhecimento ${ }^{46}$ prévio o respeito ao articulista, afinal ele tem o aval do meio de comunicação de massa, isto é, da publicação que representa.

Observamos em todos os textos a presença de um ethos seguro do tema, demonstrando conhecimento de fatos, dados, opiniões favoráveis e opiniões contrárias, apresentadas em discurso direto ou indireto. Os segmentos abaixo exemplificam esse desempenho:

\footnotetext{
${ }^{45}$ Conforme referência feita, no capítulo de contextualização teórica, buscamos a noção de linguagem como ação dramática que Koch retoma de Carlos Vogt (CF. Koch, 2004a, p. 22).

${ }^{46}$ Deborah Tannen e Cyntia Wallat, em Enquadres interativos e esquemas de conhecimento em interação, definem esquema de conhecimento como expectativas dos participantes do evento interacional acerca de pessoas, objetos, eventos e cenários do mundo (RIBEIRO, B. T., GARCEZ, P. M.(Org). 2002, p. 189).
} 
(9) Eles ficaram lá por três meses e se relacionaram muito bem com os outros primatas, principalmente Rita que estava interagindo com as fêmeas [...] (l.16)

(9) Mesmo o responsável pelo setor de tratamento dos animais do Zôo declarou que os chimpanzés estarão em melhores condições no novo recinto "Vamos resgatar uma dívida com eles e Ihes oferecer condições mais dignas." (I.38)

(32) Outro ponto não menos importante, que também conta a favor, é a valorização em $20 \%$ dos imóveis em torno do emissário submarino, segundo o Estudo de Impacto Ambiental - Relatório de Impacto Ambiental (EIA - Rima).(I.14)

Como podemos observar, no texto 9 , no primeiro segmento, temos um autor ciente dos fatos: indica o período em que os animais ficaram no novo ambiente e como se comportaram. No segundo, a transcrição da fala do responsável pelo setor dos animais do Zôo ilustra a entrevista feita pelo aluno, como complemento à pesquisa em jornais da cidade.

O texto 32 traz um dado estatístico levantado por um instituto de pesquisas, o que confere confiabilidade à opinião do aluno, afirmando seu ethos.

\subsubsection{Posicionamento do autor e intencionalidade}

Notamos que todos os textos apresentam, na introdução, um relato sobre os acontecimentos que envolvem a questão polêmica, indicando as circunstâncias em que ocorreram. Essa contextualização desperta o sentimento de presença ao qual Perelman atribui grande importância nos textos argumentativos, considerando-o 
fator essencial da argumentação, pois atua de modo direto sobre a nossa sensibilidade. A introdução, além de situar o leitor, relatando os fatos causadores da controvérsia criada, em torno de um assunto, também aponta pistas sobre o posicionamento do autor ${ }^{47}$, por meio da escolha de palavras ou expressões que desvendam seu pensamento, sua intenção. Como afirma Perelman (2005), não existe grau zero na escolha ${ }^{48}$. Observem-se grifos nossos nas passagens transcritas abaixo:

(9) Há muitos (anos) no Parque Zoológico Quinzinho de Barros, de Sorocaba, viviam dois chimpanzés Blackie e Rita que ficavam presos numa jaula fria e malcheirosa.(l.1)

(32) Há seis anos a cidade de Santos vem sofrendo com a polêmica criada em torno da construção do Museu Pelé, na Plataforma Emissário submarino, no bairro do José Menino. Devido a problemas burocráticos, o empreendimento não sai do papel. (I.6)

(89) Um fato bastante estranho aconteceu em Dois Córregos. O prefeito interditou a avenida Luiz Faulim Filho para secagem de café, provocando polêmica na cidade.(I.1)

No texto 9, por exemplo, para situar o leitor, o autor deixa claro seu posicionamento, ao usar os adjetivos fria e malcheirosa para qualificar a jaula onde estavam presos os animais. Esses caracterizadores antecipam a intencionalidade

\footnotetext{
${ }^{47}$ Cf. quadro do anexo 4.

${ }^{48} \mathrm{O}$ quadro do anexo 3 apresenta o levantamento dessas expressões.
} 
argumentativa, pois emitem um índice de avaliação ${ }^{49}$. O mesmo ocorre no texto 89 pela utilização de estranho para qualificar o fato de o prefeito interditar a avenida. Para Perelman (2005), a escolha de um adjetivo enuncia fatos incontestáveis, sendo facilmente detectável o seu aspecto avaliador. O teórico esclarece que, além do adjetivo, também os substantivos comum e próprio podem ser utilizados para efetuar essa operação. Na verdade, apoiada na organização do texto, toda escolha lexical pode exercer esse papel.

No caso do texto 32, não temos um adjetivo, mas uma expressão que indica o posicionamento do autor a respeito do empreendimento.

Interessante considerar a afirmação de Oleron (1983, p. 108):

A qualificação exprime-se no plano da linguagem pela atribuição de um rótulo que não é necessariamente um adjetivo qualificativo [...]. Tal rótulo, por si só, pelas conotações que se lhe prendem, é capaz de despertar reações positivas ou negativas no seio do público.

A expressão não sai do papel, emite um juízo de valor a respeito da lentidão da burocracia. Podemos afirmar que é lugar comum ${ }^{50}$ o sentimento da população a esse respeito, despertando no leitor uma reação simpática ao autor. Perelman (2005) considera o clichê uma estratégia argumentativa, por ser uma representação coletiva cristalizada. Ele é, para o teórico, uma figura de comunhão. Koch (2004a) denomina essas marcas lingüísticas de Índices de avaliação, ou seja, palavras ou expressões pelas quais se reconhece a posição do autor.

Ao longo da análise, verificamos que esses índices aparecem em todos os textos e não só na introdução. O quadro de dados de análises dos advérbios e

\footnotetext{
${ }^{49}$ Martins (2003, p. 79) refere-se às palavras cujo lexema exprime uma emoção, um sentimento, um estado psíquico. Afirma que "através do adjetivo o falante caracteriza emocionalmente o ser de que fala; através do substantivo abstrato destaca o sentimento, a qualidade, o estado, apresentando-os com mais realce, menos presos ao ser". Cita, como exemplos, as seguintes frases: A menina triste me comoveu. A tristeza da menina me comoveu. A tristeza sempre me comoveu.

${ }^{50}$ Para Aristóteles, a doxa.
} 
expressões atitudinais e índices de avaliaçãa ${ }^{51}$, do qual retiramos alguns exemplos, ilustra como isso ocorre:

(9) [...] essa reforma feita no zoológico deveria servir para reformar conceitos mesquinhos e egoístas de muitas pessoas. (1.56)

(32) [...] será que existe área melhor do que essa de frente para o mar? (I.30)

(71) [...] a pavimentação da estrada vicinal seria de grande importância. (I.53)

(128) [...] um ótimo investimento, oferecendo mais segurança. (I.31)

Completando, buscamos apoio em MOSCA (2004a, p. 131):

Somam-se assim causas racionais e afetivas diante dos fatos, das atitudes tomadas. De um sentimento de piedade, diante de um fato lamentável, pode-se, por exemplo, saltar para o conceito de justiçal injustiça, com base nas representações que se tem a esse respeito [...]

É o que podemos observar nos trechos retirados do texto 9:

(9) Há muitos [anos] no Parque Zoológico Quinzinho de Barros, de Sorocaba, viviam dois chimpanzés Blackie e Rita que ficavam presos numa jaula fria e malcheirosa.

Os chimpanzés eram revoltados, estressados e se irritavam com o público que muitas vezes achavam graça em atormentá-los. (sic) (I.6)

\footnotetext{
${ }^{51}$ Além desse quadro, temos análises de: tempos verbais; posicionamento do autor; operadores argumentativos e argumentos.
} 
Eles ficaram lá por três meses e se relacionaram muito bem com os outros primatas, principalmente Rita que estava interagindo com as fêmeas. (I.16)

Os primatas voltaram para o zoológico que foi reenaugurado, ficou uma beleza, jaulas com vidros, tem até cupinzeiro artificial que é o segundo do mundo, no recinto dos chimpanzés, que estão bem, mas sozinhos, tristes, vistos como bichos em extinção, presos. (sic) (l.44)

Na minha opinião resgatar seria livrá-los da prisão, para que tivessem uma vida digna, com respeito e junto com outros primatas.(1.50)

O aluno apresenta a jaula como fria e malcheirosa, desqualificando-a como moradia. Após a reforma o ambiente ficou uma beleza. Bastaria, racionalmente, para qualquer um, esse bem estar físico, os chimpanzés estão bem, mas... . Temos a força do operador argumentativo "mas", deixando clara a oposição entre ambiente salubre e ambiente emocionalmente sadio: sozinhos, tristes, como bichos em extinção, presos. Desqualifica-se novamente o ambiente, apelando para a emoção, ao utilizar os termos grifados acima, organizados em gradação. Neste momento, do sentimento de piedade ocorre um salto para o conceito de justiça, conforme indicação de Mosca (2004a). Para comentar a estratégia utilizada pelo aluno, lembramos a afirmação da mesma autora: "[...] a argumentação faz parte de todos os atos comunicativos da vida diária de qualquer cidadão, que a exercita de modo bastante intuitivo" (MOSCA, 2004a, p.132, grifo nosso).

Ainda com relação à escolha dos termos, convém analisar, nesse mesmo texto, a escolha e a utilização das palavras chimpanzé, primata e bicho. Antes, 
recorremos a Perelman (2005) sobre a questão dos valores e da hierarquia dos valores. Segundo ele, os valores, as hierarquias e os lugares do preferível são objetos de acordo acerca dos quais se pretende apenas a adesão de grupos particulares; e "a existência dos valores como objetos de acordo que possibilitam uma comunhão sobre modos particulares de agir é vinculada à idéia de multiplicidade dos grupos". Diz ainda: "recorre-se a eles para motivar o ouvinte a fazer certas escolhas em vez de outras e, sobretudo, para justificar estas, de modo que se tornem aceitáveis e aprovadas por outrem" (Ibid., p. 84). Quanto à hierarquia temos que os valores relativos às pessoas são superiores aos valores relativos às coisas; os valores relativos às pessoas são superiores aos relativos aos animais; o valor do útil é superior ao do inútil; o do justo ao útil e assim por diante.

Voltando ao texto 9, observamos que Rita e Blackie são denominados chimpanzés, especificando de que tipo de animal se trata. Vivem em um ambiente degradante; são animais, mas apresentam atitudes humanas como revolta, estresse e irritação. Nesse momento, temos uma figura de presença, a personificação, eles são elevados à categoria humana. Essa atitude do enunciador fica mais evidente no parágrafo 9, quando diz que o chimpanzé pensa, conhece, sente, odeia, se afeiçoa, sofre é igual a um humano, a única diferença é que ele não fala. Também podemos trazer, como exemplo, o parágrafo 7: O caso foi parar na Câmara Municipal de Sorocaba e uma vereadora enviou um requerimento ao Senhor Prefeito, solicitando se ele atenderia ao pedido dos chimpanzés. Para o autor das teorias argumentativas, “ [...] cada vez que desejamos tornar estáveis, concretos e presentes um grupo, uma essência, servir-nos-emos da personificação" (Ibid., p. 377). 
Os chimpanzés, ao serem transferidos para um ambiente adequado, digno, relacionam-se muito bem com outros primatas que lá moravam. A palavra primata é retomada no antepenúltimo parágrafo, para referir-se novamente aos animais que vivem nesse ambiente digno, no Santuário Ecológico Conservacionista Velho Jatobá.

Busquemos a definição de primata, no dicionário: " ordem dos mamíferos que compreende os macacos e, segundo muitos autores contemporâneos, o homem." (BUENO, 1982, p. 905). Essa definição esclarece a superioridade dos primatas em relação aos chimpanzés e os aproxima do homem, também pertencente a esse grupo. Elevar os animais à categoria humana é considerar a hierarquia dos valores, a superioridade dos valores relativos às pessoas. Colocá-los como iguais promove a adesão por meio da emoção. Quem gostaria de viver em uma jaula e ter seus direitos desrespeitados por uma atitude arbitrária do prefeito? É a regra de justiça que "[...] requer a aplicação de um tratamento idêntico a seres ou situações que são integrados numa mesma categoria" (PERELMAN; OLBRECHTS- TYTECA, 2005, p. 248).

No entanto, ao voltarem para o zoológico, independentemente da qualidade das novas acomodações, ainda assim trata-se de jaulas e eles estão presos, sozinhos, tristes, sem dignidade, vistos como bichos em extinção. Temos uma decategorização ${ }^{52}$ do referente; não são mais como seres humanos, agora são

\footnotetext{
${ }^{52}$ Lorenza Mondada e Danièle Dubois (2003, p. 22), em seu texto Construção dos objetos de discurso e categorização: Uma abordagem dos processos de referenciação, fazem um estudo sobre os processos de referenciação que participam da constituição do mundo. Em oposição à idéia de que a língua é um sistema de etiquetas que se ajustam mais ou menos bem às coisas, consideram que os sujeitos constroem, através de práticas discursivas e cognitivas social e culturalmente situadas, versões públicas do mundo. Para elas, as categorias e os objetos de discurso pelos quais os sujeitos compreendem o mundo não são nem preexistentes, nem dados, mas se elaboram no curso de suas atividades, transformando-se a partir dos contextos. Sobre decategorização, as autoras fazem a seguinte análise: “[...] quer se trate de objetos sociais ou de objetos 'naturais', observa-se que o que é habitualmente considerado como um ponto estável de referência para as categorias pode ser 'decategorizado', tornado instável, evoluir sob o efeito de uma mudança de contexto ou de ponto de vista".
} 
bichos, não pertencem a nenhuma categoria específica. Com relação a esse procedimento argumentativo, Mosca (2004a, p.130) observa que "as razões não bastam sempre para convencer, uma vez que elas não se concretizam sem 0 parecer, não bastando ser, e sem estarem ancoradas nas paixões" (grifo da autora).

Voltando à questão relativa ao posicionamento do autor diante da polêmica, a oficina 5 traz atividades que orientam os alunos quanto à necessidade de empregar expressões que tornem explícita a própria opinião, juntamente com exercícios práticos, com o objetivo de exercitar essa habilidade. Constatamos, após verificação, conforme o quadro de dados de análise do anexo 4, na página 219 , que o objetivo foi atingido. Todos os textos, excetuando-se um, o de número 32, apresentam essas expressões, como se percebe nas transcrições que se seguem:

(89) [...] portanto, sou contra a atitude do prefeito e concordo com aqueles que dizem que campanha eleitoral e dinheiro não se misturam. (I.47 - 48)

(128) Na minha opinião, os semáforos foram uma boa idéia [...] (I.13)

(130) Particularmente sou contra, pois segundo especialistas [...] (I. 8)

Na minha opinião poderiam até fazer algumas mudanças [...] (I.16)

Convém esclarecer, que o texto 32, apesar de não apresentar expressões que anunciam a posição do autor, deixa marcas de seu posicionamento, por meio da utilização de outras expressões, as orações modalizadoras, "[...] que funcionam com indicadoras das intenções, sentimentos e atitudes do locutor com relação ao seu discurso" (KOCH, 2004a, p. 136). Elas servem para modalizar o conteúdo 
proposicional que se encontra na segunda oração. Essas orações foram trabalhadas pela oficina 5. Confira-se esse recurso, nos exemplos abaixo:

(32) É evidente a importância dessa obra para a região [...] (1.7) É preciso valorizar o que é da terra [...] (I.40)

\subsubsection{Tempos verbais}

Outro aspecto que devemos considerar, nos textos semifinalistas, são os tempos verbais empregados pelos seus produtores e as situações comunicativas mundo narrado e mundo comentado - envolvidas nessa produção, segundo classificação feita por Weinrich (apud KOCH, 2004a). Esse aspecto não foi tratado nas oficinas, supomos que os alunos o conheçam por serem usuários da língua. Vamos nos apoiar nos dados levantados, que compõem o quadro do anexo 2, página 207, sobre a ocorrência dos tempos verbais em nosso corpus.

Sabemos que o artigo de opinião é um gênero de texto que pertence ao mundo comentado por apresentar uma atitude tensa de seu produtor diante do tema, pois trata de algo que o afeta diretamente, exigindo do leitor essa mesma atitude e, também, comprometimento. A utilização de verbos comentadores presente, pretérito perfeito composto, futuro do presente e as locuções verbais formadas por esses tempos - alerta e adverte o leitor sobre essa postura que deve ser assumida. É o que podemos constatar, nos exemplos abaixo, pelo emprego dos verbos ser, dar, recusar e ter, todos no presente do indicativo:

(71) Os problemas gerados pela falta de asfalto são muitos [...] (l.14) 
(76) a Prefeitura de Guarulhos não dá a atenção necessária uma vez que se recusa visitar o local para ver de perto a gravidade do problema. (I.12)

(130) Temos outras necessidades em Sertãozinho muito mais urgentes. (I.40)

Selecionamos, ainda, algumas ocorrências do futuro do presente:

(32) Isso acarretará uma melhora na economia da cidade. (I.12)

(71) Estou pensando no meu futuro, por isso lutarei $[\ldots](1.56)$

(201) [...] nosso bairro será mais valorizado e ganhará mais vida. (I.33)

Em contrapartida, se forem utilizados verbos do mundo narrado - pretérito perfeito simples, pretérito imperfeito, pretérito mais-que-perfeito, futuro do pretérito e locuções verbais formadas com tais tempos - teremos um distanciamento do fato e, por conseqüência, uma atitude "relaxada" do leitor, diante do assunto, por se tratar de eventos relativamente distantes.

Podemos afirmar que a maioria dos textos apresenta supremacia do uso dos tempos do mundo comentado, próprios do gênero artigo de opinião, como ilustra o quadro do anexo 2, com exceção dos textos 9 e 89 dos quais nos ocuparemos em momento oportuno.

Apesar do predomínio desse emprego, constatamos a presença de verbos do mundo narrado nos textos comentadores. Koch (2004a, p. 36) assegura a possibilidade de haver a co-ocorrência do pretérito perfeito simples com tempos do 
mundo comentado, fato muito comum, no português. Devem ser considerados como momentos narrativos dentro do comentário, em que se introduz um relato para servir de base a um comentário posterior ou, ao inverso, faz-se um comentário, antes de introduzir um relato. O mesmo pode acontecer com textos do mundo narrado em que se empregam verbos comentadores com o objetivo de solicitar a atenção do leitor e dar validez ao relato. A autora esclarece que deve haver concordância dos tempos num mesmo período, pois é possível passar do narrar ao comentar, ou vice-versa, só não se deve pôr em risco a compreensão, fazendo a passagem num ritmo excessivamente rápido: "[...] desse fato decorre a exigência do emprego de tempos do mesmo grupo como limitação combinatória dentro de uma oração complexa, sendo a mudança permitida, apenas, além da fronteira da oração" (lbid., p. 37). Escolhemos, dentre as várias ocorrências, uma seqüência discursiva do texto 128. Vejamos:

(I.16) Muitas pessoas afirmam que, por ser uma cidade pequena, não é necessário semáforo, dizendo que perdem muito tempo esperando abrir o sinal verde.

(I.19) Isso não é motivo para não usar semáforo porque, geralmente, as pessoas hoje em dia andam muito apressadas, algumas até alcoolizadas, e os semáforos as intimidam, dando mais organização no trânsito.

(I.24) Atualmente os acidentes com automóveis diminuíram muito na cidade, mas há um tempo atrás aconteceu um fato lamentável com um aluno da escola "Antonio de Freitas Filho" que morreu atropelado quando ia saindo da escola.[...]

(I.30) Portanto, eu sou favorável ao semáforo e o vejo como um ótimo investimento, oferecendo mais segurança aos cidadãos itaienses. 
Percebemos que, nos dois primeiros parágrafos, o produtor utilizou verbos no presente do indicativo, próprios do mundo comentado e, no parágrafo seguinte, antes de passar para outra situação comunicativa, a do mundo narrado, inicia com o advérbio de tempo "atualmente", promovendo uma mudança do presente comentador para o passado narrativo, sem comprometer a compreensão. No último parágrafo, volta ao mundo comentado, empregando o presente do indicativo. $\mathrm{O}$ relato inserido tem por objetivo fundamentar a posição do autor sobre a necessidade dos semáforos para garantir a segurança dos munícipes.

Cabe comentar o uso de semitempos, ocorridos no fragmento do texto 128. Para Weinrich (apud $\mathrm{KOCH}, 2004 a$ ), imperativo, subjuntivo, infinitivo, gerúndio e particípio são considerados semitempos por se mostrarem indiferentes à distinção entre mundo narrado e mundo comentado, não são formas verbais em sua totalidade. Eles aparecem ligados a um tempo pleno que Ihes determina a situação comunicativa. Portanto, neste caso, as flexões verbais dizendo, esperando abrir, usar, dando e oferecendo pertencem ao mundo comentado e, saindo, ao mundo narrado.

"Quando, em inobservância à concordância dos tempos, se introduz um ou mais tempos do mundo narrado no mundo comentado [ou vice-versa], tem-se o que o teórico chama de metáfora temporal” (Ibid., p. 38). Abaixo aparecem, no mesmo período, o verbo "ser" no pretérito perfeito do indicativo e o verbo "evitar" no presente do indicativo, configurando, portanto, uma metáfora temporal.

(128) [...] os semáforos foram uma boa idéia, pois evitam graves acidentes [...] (I.12) 
O desrespeito à concordância dos tempos verbais, dentro desse período, empregando-se o presente, reforça a validade do relato (Ibid., p. 221).

No caso seguinte, temos outra metáfora temporal associando o futuro do presente do verbo poder, o pretérito perfeito do verbo ter e o presente do verbo viver. Podemos dizer que o emprego do futuro faz uma prospecção, enquanto o pretérito faz um retrospectiva em relação ao tempo zero: o presente (lbid., p. 186).

(71) [...] e poderei dizer que tive o prazer de fazer algo por nós que vivemos neste lugar.(I.56)

O uso de imperfeito ou do futuro do pretérito (condicional), por exemplo, em situações comentadoras, exprime um matiz de validez limitada do discurso, exprimindo hipótese, incerteza ou irrealidade. Observemos:

(201) Precisamos de um lugar que seja grande [...] porque as crianças e os jovens trocariam as ruas que são perigosas, por um lugar em que eles estariam mais seguros $[\ldots](.17)$

É evidente a metáfora temporal de validez limitada dos fatos, exprimindo, nesse caso, uma hipótese: os jovens poderiam trocar as ruas por um lugar onde eles poderiam estar mais seguros (lbid., p. 187).

Com relação aos textos 9 e 89, notamos que os autores apresentam um relato, assumindo o papel de narrador, convidando o leitor a "[...] converter-se em simples ouvinte, com o que toda situação comunicativa se desloca para outro plano, isto é, a outro plano de consciência, situado além da temporalidade do mundo 
comentado que deixa de ter validez enquanto durar o relato" (Ibid., p. 36). São textos que, por esse motivo, são considerados como pertencentes ao mundo narrado:

(9) Eles ficaram lá por três meses e se relacionaram muito bem com os outros primatas, principalmente Rita que estava interagindo com as fêmeas. (I.16)

(89) Um cafeicultor pediu um espaço ao prefeito alegando que a colheita estava atrasada por causa da chuva, como a safra foi muito grande ele já não possuía espaço suficiente para secar o café. (I.5)

A ocorrência de tempos do mundo comentado deve-se à necessidade de o autor solicitar a atenção do leitor, imprimindo validez e comprometimento. Nos textos, esses tempos são utilizados:

a) quando o autor se posiciona, ao longo da exposição, ou traz a opinião do opositor:

(89) Algumas pessoas estão revoltadas com a atitude do prefeito, mas outras consideram que ele está certo. (I.12)

(89) ... minha cidade ainda vive no tempo dos coronéis, portanto sou contra a atitude do prefeito $[\ldots](\mathrm{l} .46)$

b) na ocorrência de metáforas temporais:

(9) [...] deveria se informar melhor [...] pois o chimpanzé pensa, conhece, sente, odeia, se afeiçoa [...] (I.34) 
(9) [...] ficou uma beleza [...] tem até tem um cupinzeiro artificial [...] (sic) (l.45)

(89) [...] a população não foi avisada com antecedência [...] essa atitude abre precedentes [...] (I.18)

(89) A avenida [...] é uma das mais movimentadas [...] dá acesso a [...] que leva a

[...] portanto não deveria estar sendo usada dessa forma. (I.29)

c) no verbo introdutor do discurso indireto nas metáforas temporais:

(89) Os que são contra dizem que o prefeito agiu com intensões políticas [...](sic)

(89) Os que são favoráveis dizem que a medida impediu a demissão dos [...] (1.21)

d) na transcrição do discurso direto nas metáforas temporais:

(9) A resposta veio com ironia: "Só em Sorocaba os chimpanzés pensam e escolhem onde desejam ficar [...]" (I.31)

(9) [...] o responsável [...] declarou que [...] "Vamos resgatar uma dívida com eles $[\ldots](1.38)$

Podemos justificar a metáfora temporal dos exemplos acima, ocorridas no texto 9, pela necessidade de seu produtor demonstrar seriedade e compromisso 
com a validez do fato. Cabe salientar, ainda, que o presente é utilizado, na maioria das vezes, quando o autor se refere aos sentimentos dos animais: "pensam", "escolhem”, "desejam", "pensa”, “conhece”, "sente”, "odeia”, “afeiçoa”, "sofre”, "é” e "fala".

Ainda que esses dois textos sejam considerados pertencentes ao mundo narrado pelos estudos de Weinrich, o texto 89, por ser altamente polifônico, por apresentar as vozes sóciais para justificar seu ponto de vista ou para se opor a elas, pode ser considerado um artigo de opinião; primeiramente, porque apesar de sua introdução ser um relato com o objetivo de situar o leitor, todas as outras ocorrências de pretérito perfeito ou futuro do pretérito se dão em metáforas temporais; em segundo lugar, porque há uma equivalência de ocorrência entre os tempos do grupo I e do grupo II, como ilustra o quadro do anexo 2. No entanto, o mesmo não se dá com o texto 9.

Mesmo assim, a composição do texto 9, desconsiderando-se a questão do tempo verbal, nos faz refletir sobre sua classificação como artigo de opinião ou não. Isso porque ele é um texto denso, com opiniões implícitas, reforçadas pela seleção lexical, já apontada, que envolve o leitor, apelando para sua sensibilidade com o objetivo de conquistar sua adesão ao ponto de vista defendido pelo autor. Complementarmente, temos o argumento de autoridade ${ }^{53}$, utilizado para sustentar a opinião e o argumento ad personam para desqualificar o opositor, o lugar do preferível, o lugar de qualidade e o posicionamento do autor, entre outros. Acredito que de todos os textos analisados, este seja o que mais apela para a emoção que, como sabemos, é o principal elemento para promover a persuasão do leitor. Transcreveremos os últimos parágrafos, esclarecendo que o termo "resgatar" foi

\footnotetext{
${ }^{53} \mathrm{O}$ argumento de autoridade e o argumento ad personam serão analisados quando tratarmos de polifonia.
} 
utilizado, anteriormente, pelo responsável pelo Zôo em: "Vamos resgatar uma dívida para com eles e lhes oferecer condições mais dignas".

(I.50) Na minha opinião resgatar seria livrá-los da prisão, para que tivessem uma vida digna, com respeito e junto com outros primatas.

(1.53) Eu penso que, se a população fosse melhor informada e pudesse dar sua opinião, os chimpanzés voltariam para o Santuário.

(I.56) E essa reforma feita no zoológico deveria servir para reformar os conceitos mesquinhos e egoístas de muitas pessoas.

Realmente, não temos o emprego da forma verbal adequada para o gênero, segundo os estudos de Weinrich (apud KOCH, 2004a). Mesmo Perelman (2005, p. 181) considera o tempo presente como aquele que expressa o universal, mas não podemos negar a qualidade do emprego das estratégias argumentativas utilizadas no texto. Comentaremos alguns aspectos presentes nos parágrafos acima como: a força que adquire a palavra "resgate" em resgatar seria livrá-los da prisão, oferecendo-Ihes uma vida digna; e a força da palavra "reforma" em essa reforma [...] deveria servir para reformar os conceitos mesquinhos; uma população mal informada que se deixa levar por promessas e aceita as atitudes arbitrárias dos seus representantes políticos em se a população fosse melhor informada e pudesse dar sua opinião: a voz do povo, que é a maioria, deveria ser respeitada - "A voz do povo é a voz de Deus". Não trataremos das outras estratégias mencionadas, pois algumas delas já foram comentadas e outras ainda o serão no decorrer das análises. 


\subsubsection{Operadores Argumentativos}

O próximo aspecto a ser considerado são os operadores argumentativos presentes nas produções estudadas. "Esses elementos inscrevem-se no discurso através de marcas lingüísticas, fazendo com que ele se apresente como um verdadeiro 'retrato' da enunciação" (KOCH, 2004a, p. 33). Para Koch (2004a, p. 108), grande parte da força argumentativa do texto está na dependência dessas marcas que são responsáveis pelo encadeamento dos enunciados, estruturando-os em textos e determinando a sua orientação discursiva.

O quadro do anexo 5, na página 220, apresenta o levantamento dos operadores argumentativos empregados pelos alunos produtores dos textos semifinalistas. A análise se justifica pelo fato de que esse aspecto é fundamental na construção do artigo de opinião e, também, por ser um dos critérios ${ }^{54}$ de avaliação utilizados pela Comissão Julgadora.

Com o objetivo de instrumentalizar os alunos, os organizadores do material, na oficina de número 5, propõem atividades que lhes permitam adquirir 0 conhecimento de alguns operadores e treinar o seu emprego.

Nos exercícios, há a presença de operadores que estabelecem relação argumentativa de explicação ou justificativa, como: porque, pois e visto que; relação em que se contrapõem argumentos orientados para conclusões contrárias: mas; e operadores que introduzem uma conclusão relativa a argumentos apresentados anteriormente: logo, portanto, então e por isso. Ressaltamos que os operadores do primeiro e do último grupo, explicação ou justificativa e conclusão, são os mais trabalhados nos exercícios; o operador "mas", no entanto, só aparece em uma

\footnotetext{
${ }^{54}$ Confira tabela com os critérios de avaliação o concurso.
} 
atividade. Isso, provavelmente, explicaria e justificaria a grande incidência dos operadores de explicação ou justificativa pois, porque e que, nos textos dos alunos, e a pequena incidência do mas, o que pode ser conferido no quadro do anexo 5 . Apresentamos, a seguir, alguns fragmentos que ilustram essas ocorrências com grifos nossos ${ }^{55}$ :

(32) É evidente a importância dessa obra para a região, pois vai gerar empregos diretos e indiretos [...] (I.7)

(71) [...] em Amadeu Amaral, porque haveria mais empregos [...] (I.54)

(201) [...] os jovens trocariam as ruas que ${ }^{56}$ são perigosas, por um lugar [...] (sic) (l.20)

(9) [...] estão bem, mas sozinhos, tristes [...] (I.48)

(128) Atualmente os acidentes com automóveis diminuíram [...] mas há um tempo atrás [...] (I.25)

Os operadores que introduzem uma conclusão, como dissemos, também foram exercitados pelas atividades. Eles estão presentes, nos textos, tendo sido usados pelo menos uma vez, com exceção do texto 9 em que não há a ocorrência desse operador.

\footnotetext{
${ }^{55}$ Todos os grifos, nos fragmentos retirados dos textos analisados, são nossos.

${ }^{56}$ Neste exemplo, o pronome relativo "que" se refere ao termo antecedente "ruas"; complementarmente, fica também uma sugestão causal: "porque tão perigosas".
} 
(32) Propõe então, que seja construído em uma outra área [...] (1.29)

(71) Eu estou pensando no meu futuro, por isso lutarei para que tenhamos o asfalto necessário [...] (52)

(76) [...] logo sou favorável à prevenção de acidentes para todos. (I.27)

(89) [...] portanto sou contra a atitude do prefeito ... (1.33)

(128) Portanto, eu sou favorável ao semáforo ... (.I.30)

(130) Por isso eu digo: "Com dinheiro não se brinca!" (I.41)

(130) Portanto, eu sou favorável à construção dessas áreas ...(I.32)

Encontramos, também o emprego dos operadores de explicação "já que" e "uma vez que", apesar de não terem sido trabalhados nos exercícios. O primeiro aparece em três textos e o segundo, em dois, exemplificando como os alunos reelaboram e reaplicam não só as noções assimiladas nas oficinas, mas também no uso da língua:

(32) [...] esses valores mudarão, já que o jogador é conhecido e admirado mundialmente. (I.20) 
(76) [...] não dá a atenção necessária uma vez que se recusa a visitar o local para ver de perto a gravidade do problema. (I.14)

O mesmo se dá com os operadores:

a) "ou" que introduz argumentos alternativos:

(32) [...] sendo construído em outra cidade ou até mesmo em outro país [...] (I.33)

(89) [...] deveria ter construído outros terreiros para secar o café ou tentar encontrar outra solução sem incomodar os cidadãos [...] (I.36)

b) "ou seja", "ou melhor" que introduzem argumentos de retificação:

(201) [...] crianças que necessitam de um lugar específico, ou seja, um lugar onde os pais possam levar seus filhos para brincar [...] (I.8)

(32) Isso seria uma grande injustiça com a cidade, já que foi em Santos, ou melhor, no Santos Futebol Clube [...] (I.35)

c) "ainda" que introduz pressupostos como:

1. mais um argumento em favor de uma determinada conclusão:

( 89) [...] dizem ainda que a medida atrapalhou o trânsito [...] (I.17) 
2. marcador de excesso temporal

(89) [...] minha cidade ainda vive no tempo dos coronéis [...] (I.46)

d) "já" que introduz pressuposto de mudança de estado

(89) [...] como a safra foi muito grande ele já não possuia espaço suficiente para secar café. (sic) (I.8)

e) "apenas" que introduz uma restrição:

(71) Atualmente há apenas bares [...] (31)

(130) [...] servindo apenas como cartão postal. (l.13)

f) "até", "até mesmo" e "mesmo" introduzem um argumento mais forte em favor de uma determinada conclusão:

(130) É perigoso até as pessoas se machucarem. (I.22)

(32) [...] sendo construído em outra cidade ou até mesmo em outro país [...] (I.33)

(9) Mesmo o responsável pelo setor de tratamento dos animais do Zôo [...] (l.38) 
g) "melhor do que" que introduz uma comparação (comparativo de superioridade):

(32) [...] área melhor do que essa de frente para o mar [...] (I.30)

h) "embora" e "apesar de" opõem dois argumentos que levam a conclusões contrárias:

(130) Embora o arquiteto responsável pela obra [...] tenha dito [...] (I.36)

(89) Apesar de algumas pessoas garantirem [... ] (I.41)

Notamos um grande índice de emprego dos operadores que somam argumentos em favor de uma determinada conclusão, "e", "também", "como também", "além disso". Vejamos:

(32) Outro ponto [...] que também conta a favor, é a valorização de $20 \%$ dos imóveis $[\ldots](1.14)$

(76) Sou a favor do semáforo, do guarda na porta da escola como também de placas de sinalização [...] (I.26)

(71) [...] além disso, muitos turistas viriam para o pesqueiro [...] (I.45) 
No caso do operador "e", há uma incidência maior de seu emprego, principalmente, no texto 71 . Ele aparece com matizes diferentes $(\mathrm{KOCH}, 2004 \mathrm{a})$, mas, na maioria dos casos encontrados, liga duas asserções, como nos exemplos abaixo, retirados dos textos:

(9) O caso foi parar na Câmara [...] e uma vereadora enviou um requerimento [...]

(89) [...] dizem que a medida impediu a demissão dos trabalhadores, e que a avenida é larga o suficiente para ser usada [...] (1.22)

(130) Irão reformar o coreto [...] e trazer um novo paisagismo [...] (I.20)

(128) [...] eu sou favorável ao semáforo e o vejo como um ótimo investimento [...] (1.30)

(71) [...] já há um projeto de pavimentação e só resta a sua aprovação, para que as obras possam começar. (1.50)

(128) [...] as pessoas hoje em dia andam muito apressadas, algumas até alcoolizadas, e os semáforos as intimidam, dando mais organização no trânsito. (sic) (I.21)

Esclarecemos que a conjunção integrante não é considerada um operador argumentativo, segundo Koch (2004a). Mesmo assim, fizemos o levantamento de seu emprego pelos autores dos artigos de opinião, pela sua forte incidência nos 
textos com grande presença de polifonia. Na maioria dos casos, seu emprego se justifica por ser o introdutor de uma oração subordinada substantiva objetiva direta, própria do discurso indireto anunciador de uma outra voz:

(76) A Secretaria [...] alega que vai contra as regras de trânsito [...] (l.19)

(89) [... ] dizem que o prefeito agiu com intensões políticas [...] (sic) (I.15)

(128) Muitas pessoas afirmam que, por ser uma cidade pequena [...] (I.16)

Com menor ocorrência, temos a conjunção integrante "que" introduzindo uma oração subordinada substantiva objetiva direta sem um verbo de elocução, não sendo, portanto, introdutora de discurso indireto:

(9) $[\ldots]$ descobriu que $[\ldots .].(24)$

(32) $[\ldots]$ poderei dizer que [...] (58)

(89) $[\ldots]$ acredito que $[\ldots](38)$

(201) Penso que $[\ldots](1.21)$

Essas análises confirmam a presença de argumentos introduzidos por operadores que auxiliam o produtor do texto a tentar influir sobre o comportamento do leitor, levando-o a compartilhar suas opiniões $(\mathrm{KOCH}, 2004 a)$. 
Lembramos que uma "[...] argumentação eficaz depende da escolha dos argumentos, da maneira de articulá-los e de os modalizar de forma adequada" (MOSCA, 2004a, p. 132). Nesse sentido, consideramos que os exercícios propostos pelas atividades auxiliaram os alunos a articular e a modalizar os argumentos.

\subsubsection{Análise da voz do outro}

Como vimos, em capítulo precedente, o diálogo entre as vozes sociais, dentro do discurso, é aspecto fundamental na constituição do sentido. É por meio das interações dialógicas entre essas vozes discursivas que o homem se constrói e constrói seu discurso. Mais uma vez, retomamos Bakhtin (2003, p. 341): "[...] os atos mais importantes, que constituem a autoconsciência, são determinados pela relação com outra consciência [...]", "ser significa conviver".

O conhecimento de mundo do aluno, por si só, já insere vozes no seu discurso. Essas vozes são "fios dialógicos vivos", constitutivos do tecido de todo discurso, que o vão tecendo polifonicamente. Bakhtin (2003) afirma que um enunciado vivo, significativamente surgido em um momento histórico e em um meio social determinados, não pode deixar de tocar em milhares de fios dialógicos vivos, tecidos pela consciência sócio-ideológica em torno do objeto de tal enunciado e de participar ativamente do diálogo social. De resto, é dele que o enunciado saiu: ele é como sua continuação, sua réplica

A manifestação desse diálogo no texto é o que Authier-Revuz (1990, p. 26) chama de heterogeneidade constitutiva do discurso, da qual todo sujeito está impossibilitado de fugir: "as palavras são, sempre e inevitavelmente, 'as palavras dos outros'." 
Ainda nessa linha de raciocínio, devemos nos lembrar de que o produtor dos artigos de opinião aqui analisados, orientado pelas atividades das oficinas, deveria buscar informações sobre o tema polêmico escolhido, tanto por meio de jornais e revistas, como também de entrevistas com pessoas da comunidade. Essas atividades de construção do repertório e as discussões propostas, na sala de aula, pelo professor, possibilitaram uma ampliação de seu conhecimento sobre o tema. Podemos dizer que essas fontes - lidas ou ouvidas - constituem manifestações e vozes das quais ele se apropria, com intenções muito claras, quando com elas concorda. Depois, essas opiniões podem ser utilizadas por ele para sustentar o próprio posicionamento com relação ao assunto, segundo uma estratégia argumentativa definida como "argumento de autoridade".

Há outras vozes das quais ele discorda e que são apresentadas com o objetivo de ridicularizar o opositor, é o argumento ad personam; ou, ainda, deixa-as evidenciadas, para rebatê-las com um contra-argumento.

Ao explicitá-las, delimitá-las, em alguns casos, o autor do texto evidencia os limites entre o seu discurso e o discurso do outro: "[...] de que outro é preciso se defender, a que outros é preciso recorrer para se constituir [...]", trata-se da heterogeneidade mostrada que pode ser explícita ou implícita (AUTHIER-REVUZ, 1990, p.31). Em outros casos, a distinção é menos clara, como se verá adiante. 


\subsubsection{Heterogeneidade mostrada}

Inicialmente, verificamos, nos textos, a presença explícita do outro pelas formas da heterogeneidade mostrada, ou seja, marcadas pelo uso de aspas, pelo discurso direto ou pelo discurso indireto.

Em primeiro lugar, trataremos do discurso indireto. É por meio dele que o enunciador, colocando-se enquanto tradutor, usa de suas próprias palavras para remeter a uma outra fonte do "sentido" (BRANDÃO, 2002, p.50). Temos, portanto, apenas um enunciador que se encarrega do conjunto da enunciação, “conseqüentemente, não há mais que 'uma situação de enunciação', a do discurso citante" (MAINGUENAU, 1996, p. 109). Retiramos dos textos alguns fragmentos, com o objetivo de ilustrar esse recurso ${ }^{57}$ : a princípio, casos em que o autor se apropria da voz do outro com o objetivo de fortalecer sua posição diante do assunto, o que, para Perelman (2005), constitui o argumento de autoridade. Isso ocorre quando se mencionam atos ou juízos de uma pessoa ou de um grupo de pessoas, como prova a favor de uma tese.

Vejamos os exemplos, com grifos nossos:

(89) Os que são contra dizem que o prefeito agiu com intensões políticas ... (sic)

(89) [...] o promotor de justiça de Dois Córregos afirmou que "a medida é juridicamente discutível”. (I.44)

\footnotetext{
${ }^{57}$ O quadro do anexo 6, apresenta, de forma completa, nosso levantamento.
} 
(130) [...] com a troca de todo o piso, que dizem que será escorregadio. (I.21)

Podemos notar, a partir dos fragmentos, que a voz da autoridade invocada é variável. No primeiro e no terceiro exemplos, o autor buscou a voz dos cidadãos, a força da coletividade, traduzida no último pela indeterminação do sujeito; no segundo, transcreve-se opinião de um promotor de justiça, o que denota seriedade de um testemunho válido, sua autoridade é reconhecida oficialmente. Aproveitamos para apresentar outros casos de ocorrência desse tipo de estratégia argumentativa $^{58}$, também aqui com grifos nossos:

(9) [...] o Dr. Pedro Ynterian, bioquímico, microbiologista, autoridade reconhecida internacionalmente no que refere a primatologia e coordenador do projeto GAP no Brasil, descobriu que Blackie e Rita não queriam voltar mais para o zoológico. (sic) (l.20)

(32) Outro ponto não menos importante, que também conta a favor, é a valorização de $20 \%$ dos imóveis em torno do Emissário Submarino, segundo o Estudo de Impacto Ambiental - Relatório de Impacto Ambiental (EIA- RIMA).

(89) [...] como já foi publicado no jornal da cidade o cafeicultor é o maior produtor da região. (sic) (I.39)

(130) [...] segundo especialistas, essa restauração está saindo muito cara. (I.9)

\footnotetext{
${ }^{58}$ O quadro do anexo 6 apresenta outras ocorrências desse tipo de argumento utilizado pelos produtores dos textos analisados.
} 
Notamos que os alunos buscaram vozes inquestionáveis de autoridades reconhecidas e respeitadas pela comunidade, às quais se credita confiabilidade: um bioquímico, autoridade reconhecida mundialmente; dados de valorização dos imóveis, apresentados pelo Relatório de Impacto Ambiental; informações noticiadas no jornal da cidade e opinião de especialistas.

Já nos casos abaixo, o discurso indireto é apresentado pelo autor com a intenção de dar voz ao opositor para, depois, refutá-la com um contra-argumento. Os destaques em negrito são nossos:

(76) A Secretaria de Transportes do município alega que vai contra as regras de trânsito instalar semáforos em ladeiras. (I.19)

(89) Os que são favoráveis dizem que a medida impediu a demissão dos trabalhadores [...] (I.21)

(128) Muitas pessoas afirmam que, por ser uma cidade, não é necessário semáforo $[\ldots](1.16)$

Interessante observar, nos exemplos acima, os diferentes verbos introdutores: "alegar", "dizer" e "afirmar". Sobre esse dado, Maingueneau (2001, p.150) expõe que, tanto no discurso direto quanto no discurso indireto, "[...] a escolha do verbo introdutor é bastante significativa, pois condiciona a interpretação, dando um certo direcionamento ao discurso citado". Esclarece que, no discurso indireto, todos os níveis de subjetividade enunciativa são afetados pela perda da autonomia, ou seja, "assistimos ao desaparecimento das exclamações, das interrogações, dos 
imperativos etc. do discurso citado" e, na falta de marcas de distanciamento explícito, não se sabe a quem atribuir os traços de subjetividade e as palavras empregadas: "se ao relator ou ao locutor" (MAINGUENAU, 2001, p.109-110).

Com a intenção de evidenciar o caráter argumentativo dessa escolha, buscamos em BUENO (1982), as definições dos verbos empregados e podemos afirmar que: o primeiro, alegar, sugere que o enunciador do discurso citado, em sua defesa, apresenta uma "justificativa", como prova de seu posicionamento. O segundo, dizer, é mais neutro, não fica claro o tom do que foi enunciado; já o terceiro, afirmar, é o mesmo que "asseverar, declarar com firmeza". Ao empregar o verbo alegar para introduzir a voz do outro, o autor do texto indica claramente que a Secretaria de Transportes da prefeitura foi acusada pela população de não tomar providências imediatas para garantir a segurança dos alunos, instalando o semáforo pedido; logo, a Secretaria "alega" para se defender, se justificar. Isso já não ocorre com o verbo dizer que, por sua vez, é diferente de afirmar. Charaudeau, P. e Maingueneau, D. (2004, p.176) consideram que a maneira como se apresenta o discurso citado aponta "a maneira pela qual quem cita avalia o enunciado citado para integrá-lo[...]" ao próprio discurso. Podemos constatar que a escolha do verbo introdutor está ligada à estratégia argumentativa do autor do texto, regulando de que forma a voz do outro chegará até o leitor, direcionando sua interpretação a respeito dos fatos apresentados.

Em um dos textos, o de número 9 , chamou-nos a atenção o fato de o produtor utilizar o discurso direto, que se caracteriza por uma dissociação clara entre as duas situações de enunciação: a do discurso citante e a do discurso citado, como forma marcada de heterogeneidade mostrada. 
Segundo Maingueneau (2001, p. 137 - 141), o indivíduo que fala e se manifesta como "eu", no enunciado, é também aquele que se "responsabiliza" por esse enunciado: ele situa-se como fonte de "referências enunciativas", ancora o enunciado na enunciação e posiciona-se como "responsável pelo ato de fala". Quando o enunciador cita, no discurso direto, a fala de alguém, não se coloca como responsável por essa fala, exime-se, portanto, de qualquer responsabilidade. Além de simular restituir as falas citadas, cria uma espécie de "encenação", visando a sugerir autenticidade. O teórico afirma que, por mais que seja fiel, o discurso direto é sempre apenas um fragmento de texto submetido ao enunciador do discurso citante, que dispõe de múltiplos meios para lhe dar um toque pessoal. Portanto, os verbos introdutores do discurso direto não são neutros e trazem consigo um enfoque subjetivo; caso haja a intenção de demonstrar neutralidade, omitir-se-á o verbo introdutor. Este recurso resulta em certo distanciamento.

Afirma que a escolha do discurso direto pode estar ligada à estratégia de cada texto. Pode-se procurar: i) autenticidade, indicando que as palavras relatadas são aquelas proferidas; ii) distanciamento, seja porque o enunciador citante não adere ao que é dito e não quer misturar esse dito com aquilo que ele efetivamente assume; seja porque o enunciador quer explicitar, por intermédio do discurso direto, sua adesão respeitosa ao dito, fazendo ver o desnível entre as palavras prestigiosas, irretocáveis e as suas próprias palavras [citação de autoridade]; iii) evidência de uma posição objetiva e séria (Ibid., p. 142).

Vejamos os exemplos:

(9) A resposta veio com ironia: "Só em Sorocaba os chimpanzés pensam e escolhem onde desejam ficar ..." (I.31) 
(9) [...] o responsável pelo setor de tratamento dos animais do Zôo declarou que os chimpanzés estarão em melhores condições no novo recinto: "Vamos resgatar uma dívida com eles e Ihes oferecer condições mais dignas". (I.38)

Nos dois casos, observamos um distanciamento do enunciador citante que não adere ao que é dito. Analisemos, especialmente, o primeiro deles. Nele, o produtor, ao utilizar a palavra "ironia", evidencia seu posicionamento diante da resposta do prefeito; não temos um verbo introdutor explícito, mas a expressão "respondeu ironicamente" pode ser considerada um índice de avaliação, conforme dados presentes no quadro do anexo 3 na página 216. Com o objetivo de confirmar nossa análise, transcreveremos o contra-argumento utilizado imediatamente após o discurso direto a que estamos nos referindo:

(9) O Sr. Prefeito deveria se informar melhor antes de falar [...] (sic) (I.34)

É evidente a intenção argumentativa do autor do texto, ao utilizar o discurso direto: ele deu voz ao enunciador citado, distanciou-se, por não aderir ao que foi dito e posicionou-se, ao empregar o modalizador "ironicamente". Ou seja: o prefeito é uma pessoa que, neste caso, agiu de forma irônica e também desrespeitosa, por não demonstrar consideração pelos animais. Logo após, utiliza o pronome de tratamento "senhor", em "O Sr. Prefeito", mostrando percepção do distanciamento entre a autoridade investida àquele que foi eleito pelo povo para atender às necessidades da população e sua atitude irônica diante de um assunto tão importante; o verbo dever, deôntico, que imprime a idéia de responsabilidade, de 
dever moral, seguido por "se informar melhor", acrescenta a idéia de que o político também se mostrara "mal informado" a respeito do caso.

Perelman (2005) afirma que se pode utilizar um argumento para desqualificar o outro, ad personam, denunciando a incompetência do até então considerado competente, como no exemplo analisado acima. Fica evidente ainda, no discurso direto citado no texto 9 , a falta de coerência entre o papel social do prefeito - sua pessoa - e seus atos. O autor suíço esclarece que, pelos atos, podemos construir e reconstruir a nossa imagem da pessoa e que "a reação do ato sobre o agente é capaz de modificar constantemente a nossa concepção de pessoa[...]" (Ibid., 337); salienta, também, que merece especial atenção o discurso como ato do orador, pois ele é a manifestação por excelência da pessoa, é a impressão que dá de si mesmo por meio das próprias palavras.

Continuando nossa análise, apresentamos casos especiais, como os selecionados, a seguir, encontrados em dois textos, com destaques nossos:

(89) [...] o promotor de justiça de Dois Córregos afirmou que a "medida é juridicamente discutível”. (I.44)

(130) Embora o arquiteto responsável pela obra, Adelino Fontana Jr, tenha dito que “existia uma grande confusão de conceitos”[...] (sic) (I.36)

Nos exemplos acima, além dos verbos de elocução, próprios do discurso indireto, os autores marcaram com aspas a transcrição literal da fala dos produtores do discurso. Mainguenau (1996, p. 151) define essa ocorrência como forma híbrida, ou seja, quando o enunciador citante isola entre aspas um fragmento que, ao 
mesmo tempo, "[...] ele utiliza e menciona, emprega e cita[...]". Temos globalmente o discurso indireto que contém um fragmento, chamado de "ilha" enunciativa, atribuído aos enunciadores citados. Especificamente, no primeiro caso, o autor do texto utiliza a seu favor a fala do promotor como argumento de autoridade; dar voz ao enunciador citado e transcrever suas palavras, "medida juridicamente discutível", pertencentes a um nível lingüístico que não é o seu próprio, dá um peso maior ao ponto de vista defendido, fortalecendo a estratégia para convencer o leitor, são palavras “irretocáveis", segundo Maingueneau (2001, p. 142).

Um outro modo "mais simples para um enunciador indicar que não é o responsável por um enunciado" é a modalização em "discurso segundo" (MAINGUENEAU, 2001, p. 139). Constatamos também essa ocorrência:

(89) Segundo ele, se o prefeito não cedesse um espaço, ele teria que parar com a safra e demitir duzentos trabalhadores rurais. (I.9)

(71) De acordo com as informações obtidas com o subprefeito [...] (I.18)

(130) Particularmente sou contra, pois segundo especialistas [...] (I.8)

Finalmente, o último caso de forma marcada de heterogeneidade mostrada explícita de que trataremos, são as aspas. Maingueneau (2001, p. 160-161) denomina modalização autonímica ${ }^{59}$ o uso desse sinal gráfico. Sem romper a ordem da sintaxe, o enunciador "[...] chama a atenção do co-enunciador para o fato de estar empregando exatamente as palavras que ele está aspeando[...]”; salientando-

\footnotetext{
${ }^{59}$ Authier-Revuz (1990, p. 29) utiliza a expressão “conotação autonímica”.
} 
as, delega a este a tarefa de avaliar o motivo de seu emprego, abrindo uma lacuna a ser preenchida interpretativamente. Portanto, esse uso expressa uma intencionalidade. O teórico afirma que, muitas vezes, aspear uma palavra significa transferir a responsabilidade de seu emprego a outra pessoa, demonstrando um afastamento ou uma aproximação. Esse "outro" pode ser, por exemplo, um elemento usado por um grupo social ou por um partido político ou, ainda um clichê, um estereótipo.

Completa, dizendo que "o enunciador que faz uso das aspas, conscientemente ou não, deve construir para si uma determinada representação de seus leitores[...]", com os quais é necessário uma conivência mínima e que, "para descobrir a razão do emprego das aspas e interpretá-las, o leitor deve levar em consideração o contexto e, especialmente, o gênero de discurso" (Ibid., p. 162 163).

No corpus estudado, encontramos quatro casos de modalização autonímica:

(9) [...] Parque Zoológico "Quinzinho de Barros” [...] (I.1)

(9) [...] Santuário Ecológico Conservacionista "Velho Jatobá" [...] (I.13)

(32) Devido a esses impasses, o "rei" do futebol já está ficando sem paciência [...]

(130) Por isso eu digo: "Com dinheiro não se brinca!" (I.41) 
Nos dois primeiros exemplos, as aspas foram empregadas para destacar os nomes dos locais citados. No terceiro, "rei", que faz parte da perífrase "rei do futebol", pode ser interpretada como um realce ao fato de Pelé ser considerado um rei e, portanto, não poder ser irritado pela morosidade do andamento do projeto, devido a questões burocráticas. Segundo Perelman (2005), a perífrase é uma figura de seleção dotada de grande força persuasiva e apresenta grande efeito argumentativo. No último exemplo, temos um provérbio $^{60}$, a doxa para Aristóteles, figura de comunhão para Perelman (2005), é o senso comum utilizado como argumento que visa à adesão do leitor; há uma aproximação entre o discurso citado - provérbio - e a opinião do enunciador: crítica à atitude do prefeito em gastar dinheiro público, na reforma da praça da cidade, ao invés de aplicá-lo em saúde e educação, atitude reforçada pelo uso da pontuação exclamativa. Vale lembrar que, para o autor belga, a modalidade optativa talvez seja a que melhor se presta à expressão das normas (Ibid., p.181).

\subsubsection{Heterogeneidade constitutiva}

Buscamos verificar, também, a voz do outro não marcada, ou seja, implícita, evidenciada pela presença de palavras e construções que não fazem parte do repertório do aluno dessa faixa etária, perceptível em praticamente todos os textos. Para Authier-Revuz (1990), a natureza desta alteridade pode não ser especificada no contexto do fragmento, é a forma implícita da heterogeneidade mostrada:

Ela é implícita [...] pelas aspas e pelo itálico não glosados; em outras palavras, toda compreensão, interpretação destas marcas passa por uma especificação da alteridade a que remetem, em função de seu ambiente discursivo: por exemplo, uma outra língua, variedade de

\footnotetext{
${ }^{60}$ Provérbios, como vimos, são máximas curtas, tornadas populares; por exprimir um acontecimento particular, sugerem uma norma e apresentam um caráter de ensinamento, fazendo parte do repertório da cultura popular.
} 
língua, um outro discurso diferente, um discurso oposto, etc. (Ibid., p. 30).

Nos casos analisados, temos uma outra variedade da língua empregada pelos autores, seja de caráter profissional, seja de registro culto. Isso poderia ser um sintoma da interferência direta ou indireta das pessoas que participaram da construção do texto com os alunos. Ou, eventualmente, das que o leram e fizeram sugestões ou, ainda, das que o corrigiram, o avaliaram. Devemos considerar também a possível apropriação feita pelos produtores, a partir de suas pesquisas em jornais e revistas. Trata-se de questionamento complexo e difícil de esclarecer. Como não acompanhamos o processo, podemos apenas verificar e apontar as marcas e indícios dessa interferência.

Consideramos que a evidência desses indícios, nos textos discentes, não invalida nem o projeto nem o concurso. Uma vez analisada e constatada nos produtos, essa presença deve possibilitar uma retificação de rumos no processo, a fim de reduzir ao máximo possível essas intervenções voluntárias ou involuntárias na produção dos alunos, por bem intencionadas que possam ser.

Retiramos dos textos, alguns fragmentos com a finalidade de exemplificar nossa afirmação, marcando em negrito as palavras a que nos referimos e que, inegavelmente, não costumam fazer parte do repertório cultural e lingüístico de redatores entre 10 e 11 anos de idade. De início listamos doze exemplos com termos praticamente exclusivos da linguagem culta adulta. As quatro últimas frases ilustram casos de linguagem culta que sugerem inspiração em textos cultos.

1) (9) [...] enviou um requerimento [...] solicitando se atenderia o pedido [...] (I.28) 
2) (32) [...] terá três andares, abrigando ainda lojas [...] (l.10)

3) (32) Devido a esses impasses [...] (31)

4) (71) Os problemas gerados pela falta de asfalto são muitos [...] (l.14)

5) (76) [...] um semáforo na frente da escola com o intuito de promover maior segurança para as crianças. (I.4)

6) (89) [...] essa atitude abre precedentes para outros produtores solicitarem o mesmo benefício $[\ldots](\mathrm{l} .19)$

7) (89) Pelo jeito minha cidade ainda vive no tempo dos coronéis [...] (I.46)

8) (128) [...] o prefeito sucessor [...] (1.9)

9) (130) [...] porque era feia e suja devido aos dejetos dos pássaros [...] (I.6)

10) (130) O término do trabalho está com previsão [...] (I.20)

11) (201) [...] os políticos deveriam investir mais em bairros periféricos [...] (I.12)

12) (201) [...] elas podem pagar o alto custo de uma passagem para ir ao cinema $[\ldots](1.26)$ 
13) (9) Eles ficaram lá por três meses e se relacionaram muito bem com os outros primatas $[\ldots](\mathrm{I} .16)$

14) (71) [...] já há um projeto de pavimento e só resta a sua aprovação [...] (I.49)

15) (76) [...] com cruzamento perigoso, ocasionando assim, vários acidentes. (sic)

16) (128) [...] algumas até alcoolizadas, e os semáforos as intimidam [...]

A simples leitura dessas frases nos leva a pensar que não é comum esses termos fazerem parte do repertório de uma criança de $4^{\underline{a}}$ ou $5^{\underline{a}}$ séries; são palavras e construções inabituais, dificilmente empregadas em textos de crianças com idade entre 10 e 11 anos.

Por vezes, o modo de tratar o tema apresenta preocupações muito mais próximas do universo adulto do que do infantil como, no exemplo, citado a seguir, com o verbo em primeira pessoa, implicando o autor na questão tratada:

(130) Penso que o número de desempregados aumentará [...] (I.23)

Acreditamos que, mesmo se a criança vivenciar uma situação familiar de desemprego, a projeção dos efeitos de uma reforma na cidade não a levaria a previsões dessa ordem. No mesmo texto, o de número 130, temos o provérbio "Com dinheiro não se brinca", no título e no fechamento, o que nos parece muito distanciado do universo dos pré-adolescentes. Os casos apontados, de 
heterogeneidade constitutiva implícita, colocam em evidência um modo de dizer/ escrever inabitual nos alunos a que o projeto se destina.

Voltamos a reiterar que nossa proposta é a análise do produto e não, do processo. Reafirmamos, igualmente os muitos méritos do Prêmio Escrevendo o Futuro. No entanto, com o intuito de realizar um trabalho sério, não podemos deixar de apontar esses casos. Sugerimos que se inclua nas oficinas das próximas edições, um conjunto de estratégias de análise, evidenciando como a heterogeneidade se manifesta nos produtos finais. Talvez seja um caminho operacional para resolver a questão.

Cabe-nos, indicar o levantamento que fizemos sobre a presença desses elementos nos textos que, juntamente, com os outros casos de polifonia analisados, comprova a teoria bakhtiniana do dialogismo, em que a tessitura do discurso é feita pelo entrelaçamento das diversas vozes presentes, nos textos. Esta teoria baliza o que Authier-Revuz (1990) chama de heterogeneidade constitutiva da qual todo sujeito está impossibilitado de fugir e heterogeneidade mostrada por inscreverem o outro na seqüência do discurso. Constatamos, também, uma estratégia argumentativa do produtor do texto, entre outras já tratadas, ao utilizar o argumento de autoridade para apoiar seu ponto de vista e o argumento ad personam para desqualificar o opositor. Esses índices demonstram que o aluno compreendeu a característica do gênero artigo de opinião como um gênero argumentativo ao aplicar o que exercitou nas atividades propostas pelas oficinas do concurso.

Sugerem, ainda, nos casos de heterogeneidade constitutiva - que, se aceitou a participação direta ou indireta da voz adulta, ele o fez com o intuito de argumentar da melhor forma possível. Resta saber se seria possível a orientação e o 
acompanhamento da atuação dos adultos, para que essa forma de heterogeneidade só se evidenciasse, no texto, pela vontade do próprio redator.

As análises feitas, neste capítulo, demonstram que todos os textos do corpus atendem às exigências do concurso quanto ao emprego das estratégias argumentativas $^{61}$ utilizadas pelos alunos-autores: tomada de posição; apresentação de dois ou mais argumentos para convencer o leitor; consideração pelo ponto de vista dos opositores; conclusão com reforço da posição tomada e utilização de expressões que introduzam e evidenciem a posição tomada pelo autor e a conclusão.

Além disso, o levantamento feito, no anexo 6, confirma os estudos de Perelman (2005) sobre a interação dos argumentos:

Os elementos isolados com vistas ao estudo formam, na realidade, um todo; estão em interação constante, e isso em vários planos: interação entre diversos argumentos enunciados, interação entre estes e o conjunto da situação argumentativa, entre estes e sua conclusão e, enfim, interação entre os argumentos contidos no discurso e aqueles que têm este último por objeto (Ibid., p.525).

O teórico diz que por mais imprecisas que sejam as condições em que se desenvolvem os fenômenos de interação, são eles que determinam em grande parte a escolha dos argumentos, a amplitude e a ordem da argumentação (lbid., p. 524).

\footnotetext{
${ }^{61}$ A tabela com os critérios de avaliação do concurso encontra-se na página 88.
} 


\section{CONCLUSÃO}

Ao longo de nossos estudos, pesquisas e análises, fomos levados a refletir sobre várias questões a respeito do ensino de língua materna, como as dificuldades enfrentadas por professores e alunos, os sucessos, os resultados obtidos após os anos de estudo a que são submetidos os falantes da língua, os benefícios do trabalho com gêneros textuais, a apropriação do gênero por meio de seqüências didáticas e o lugar da gramática no ensino, para conduzir o aluno a ampliar gradualmente o domínio competente da modalidade escrita.

Dividiremos nossas considerações finais em duas partes: a primeira tratará de nossas reflexões sobre o ensino de Língua Portuguesa, após as pesquisas realizadas; a segunda tratará do concurso no âmbito do qual foi produzido nosso corpus, por meio da análise do material de apoio ao professor contendo as orientações e as oficinas.

Nossa expectativa é de apresentar uma dupla contribuição. Talvez possamos indicar um caminho operacional aos colegas que lecionam Língua Portuguesa. E, paralelamente, indicar sugestões para o aperfeiçoamento dos materiais que compõem o "kit" do Prêmio Escrevendo o Futuro.

Nosso olhar, a princípio limitado, focava crianças do ensino fundamental I que, participando de um concurso, foram submetidas a um processo de aquisição de um gênero textual por meio de seqüências didáticas. Mais adiante, esse mesmo olhar passou por um processo de ampliação, por considerarmos similares as dificuldades enfrentadas pelos usuários da língua, em diferentes níveis de ensino e faixas etárias. 
Sabemos que o ensino da língua, em grande parte das escolas, está voltado para os estudos metalingüísticos gramaticais, de caráter normativo, por meio de frases descontextualizadas, mesmo que tenham sido retiradas de textos ${ }^{62}$.

As estruturas dos "gêneros" escolares - narração, descrição e dissertação costumam ser o foco do trabalho com a escrita, resistindo a mudanças. Em alguns poucos casos, os exercícios de língua escrita recorrem à lingüística textual, trabalhando coesão e coerência, como etapa intermediária entre a leitura do texto e a classificação gramatical. Raras são as situações em que se realizam atividades epilingüísticas ou de exercitação do uso da língua, de verificação dos efeitos de sentido que os recursos gramaticais produzem no texto.

A partir da publicação dos Parâmetros Curriculares Nacionais [PCNs], em 1997/ 1998, oficializou-se a indicação de uma mudança no ensino da escrita e, a partir daí, também, uma ênfase na abertura de espaço para a aquisição dos gêneros orais. São propostas em que o texto assume sua importância, seu significado dentro do contexto do aprendiz, deixa de ser artificial e ter como único leitor o professor. Passam a ser consideradas a situação de produção, a circulação dos textos e a significação que neles é construída - sua função social.

A mudança de postura diante do ensino de Língua Portuguesa mostra-se, no entanto, difícil e lenta. Profissionais da sala de aula sentem-se presos a métodos aprendidos com seus professores que por sua vez aprenderam com os deles e, assim, sucessivamente, passa-se adiante essa herança do ensino da língua.

Salvo exceções, ainda verificamos dificuldade, por parte do professor, em assumir a nova postura diante do ensino da língua escrita e oral, apesar de sugestões dos PCNs, como as seguintes:

\footnotetext{
${ }^{62}$ Cf. O texto na sala de aula: Leitura e produção de Geraldi, J. W. (1985).
} 
Ainda que a unidade de trabalho seja o texto, é necessário que se possa dispor tanto de uma descrição dos elementos regulares e constitutivos do gênero, quanto das particularidades do texto selecionado [... ] (PCNs $3^{\circ}$ e $4^{\circ}$ ciclos do ensino fundamental, p. 48).

Os textos organizam-se sempre dentro de certas restrições de natureza temática, composicional e estilística, que os caracterizam como pertencentes a este ou aquele gênero. Desse modo, a noção de gênero, constitutiva do texto, precisa ser tomada como objeto de ensino (lbid., p. 23).

[...] nas inúmeras situações sociais de exercício da cidadania que se colocam fora dos muros da escola - a busca de serviços, as tarefas profissionais, os encontros institucionalizados, a defesa de seus direitos e opiniões - os alunos serão avaliados (em outros termos, aceitos ou discriminados) à medida que forem capazes de responder a diferentes exigências de fala e de adequação às características próprias de diferentes gêneros do oral [...] A aprendizagem de procedimentos de fala e escuta, em contextos públicos, dificilmente ocorrerá se a escola não tomar para si a tarefa de promovê-la (Ibid., p. 25).

Acreditamos que o ensino só tem sentido se atender às necessidades dos alunos e torná-los capazes de usar a língua para o exercício da cidadania.

Roxane Rojo e Glaís Sales Cordeiro, no texto "Apresentação: gêneros orais e escritos como objeto de ensino: modo de pensar, modo de fazer" que abre o livro Gêneros orais e escritos na escola (2004), de que são organizadoras e tradutoras, fazem considerações em que nos apoiamos. Elas afirmam: "recentemente, no Brasil, tem-se visto bastante preocupação e discussão a respeito do fato de que as práticas escolares brasileiras tendem a formar leitores, ao final do ensino médio, com apenas as capacidades mais básicas de leitura, ligadas à extração simples de informação de textos relativamente simples" (In. SCHNEUWLY, B.; DOLZ, J., 2004, p.10).

Testes como o PISA [Project for International Student Assessment] verificaram a competência de alunos com 15 anos, representantes de 40 países, em três domínios: leitura, matemática e ciências, classificando o Brasil, quanto à capacidade de leitura, em último lugar, em 2000, e 37일 lugar em 2003. Resultados 
insatisfatórios também são registrados em avaliações internas como o ENEM [Exame Nacional do Ensino Médio]. Esses dados comprovam a urgente necessidade de mudanças.

Sabemos que algumas ações são assumidas por governos de alguns estados com o objetivo de instrumentalizar o professor como, por exemplo, o Ensino Médio em Rede, em São Paulo, que, em sua última edição apresentou um trabalho sobre artigos de opinião. Mas verificamos que a formação é incompleta, os materiais de apoio insuficientes, os recursos didáticos precários e a mudança, muito lenta.

Apesar das desfavoráveis condições de trabalho, consideramos possível buscar novos caminhos. Entendemos que a proposta de Schneuwly e Dolz (2004) para a aquisição da competência do escrito e do oral, por meio dos gêneros textuais e atividades estruturadas em seqüências didáticas, apontam um caminho operacional para este momento que clama com urgência por novas ações e novas posturas diante do ensino da língua. O ensino por meio do gênero, nos moldes da seqüência, pode apoiar a aquisição da língua escrita e oral, transformando, também, o trabalho com a norma gramatical. Cada gênero tem suas características e sua linguagem específica. Ao analisá-lo ou produzi-lo, surge o momento ideal para o estudo de suas marcas lingüísticas, possibilitando uma análise lingüística voltada para o emprego de recursos gramaticais, em função dos efeitos de sentido que eles produzem no texto.

As várias propostas de agrupamentos de gêneros discursivos exigirão do professor, ao selecionar aqueles com os quais trabalhará, a consideração de fatores como a idade dos alunos, suas habilidades lingüísticas, as necessidades sociais do contexto em que se encontram, a avaliação do gênero mais apropriado ao universo 
do discente, em função da sua circulação dentro e fora da escola (LOPES-ROSSI, 2002, p.34).

Roxane Rojo e Glaís Sales (In SCHNEUWLY, B.; DOLZ, J., 2004, p.17) salientam que, dentro desses critérios de escolha, pode-se considerar que alguns agrupamentos de gêneros são mais relevantes para a formação da cidadania no Brasil, como se menciona nos PCNs:

a) narrar: importante para a formação do leitor literário e do ser humano em geral, dado o caráter formador da arte;

b) expor: necessário para a atuação do estudante e do profissional bemsucedido em muitas áreas;

c) argumentar: útil para a vida profissional e para a conscientização do cidadão defensor de seus direitos.

Esses critérios foram utilizados por elas para organizar o livro dos autores franceses. Esclarecem que, como toda escolha, alguns agrupamentos foram deixados de lado como relatar, instruir/ prescrever.

A nosso ver, é evidente, que se pode trabalhar com qualquer um dos agrupamentos, desde que o professor sinta sua validade e necessidade.

Schneuwly e Dolz (2004) consideram uma boa estratégia geral a concepção de "ensino em espiral", por meio da retomada dos gêneros, em etapas sucessivas, aumentando-se a complexidade da abordagem, de acordo com a faixa etária dos alunos. Alguns subgêneros são menos complexos por aproximarem-se mais dos gêneros orais - primários ou espontâneos, segundo Bakhtin (2003) - como, por exemplo, o gênero carta, enquanto outros - secundários -, por distanciarem-se mais, são mais complexos e apresentam maior dificuldade, como o artigo de opinião. 
Quanto ao ensino do agrupamento do gênero "argumentar", foco de nosso trabalho, pudemos compreender, por meio dos autores pesquisados, que é possível e necessário um trabalho para sua aquisição. Possível, pois as crianças apresentam condições para desenvolvê-lo, uma vez que já defendem suas opiniões desde a mais tenra idade; necessário, pois "argumentação eficaz depende da escolha dos argumentos, da maneira de articulá-los e de os modalizar de forma adequada" (MOSCA, 2004a, p.132). Cabe, no entanto, considerar as questões levantadas quando da escolha do subgênero, questão que retomaremos adiante.

Feitas as considerações gerais, direcionamos nossas reflexões para o concurso com o qual trabalhamos, cujo maior objetivo é o desenvolvimento da habilidade de escrita de crianças do ensino fundamental I de todo o país.

Se levarmos em conta os textos semifinalistas, representantes das mais diversas regiões brasileiras, concluímos que milhares de alunos tiveram a oportunidade de produzir textos dos gêneros "memória", "poesia" e "artigos de opinião" e vivenciaram atividades de leitura, pesquisa, escrita, reescrita e reflexão sobre a língua. Professores de todo o país receberam o material de apoio e tiveram a oportunidade de vivenciar novas estratégias de ensino, motivados pela disputa de um prêmio que envolveu a escola e a comunidade.

Louzada (1996) afirma que a dificuldade dos alunos diante da atividade de escrita, por exigir grande esforço cognitivo na transformação da linguagem oral espontânea - gênero primário - em linguagem escrita - gênero secundário que necessita de complexos mecanismos de controle sujeitos à aprendizagem escolar -, exige um planejamento de situações didáticas que dêem suporte para a atividade de escrita. Esclarece que uma maneira de diminuir essa carga cognitiva é munir o aluno de informações sobre o tema de que tratará em seu texto, ou seja, elaborar com ele 
a construção do repertório. As oficinas do Prêmio propiciaram atividades em que os alunos fizessem entrevistas com pessoas envolvidas na questão trabalhada por eles, assim como pesquisas em jornais e revistas. Portanto, eles tiveram onde se apoiar para defender seu posicionamento e refutar opiniões contrárias.

Dessas ações e desse contato com opiniões diversas, surgiu a multiplicidade de vozes ou polifonia, perceptível nos textos, como evidenciou a análise do corpus, tanto pela heterogeneidade mostrada, quanto pela constitutiva. A heterogeneidade mostrada é um processo intencional, utilizado tanto para fortalecer o ponto de vista do produtor do texto quanto para rebater a opinião do opositor com um contraargumento. Quanto à heterogeneidade constitutiva, provavelmente sua utilização não tenha sido intencional. Sabemos que as entrevistas, as leituras, as pesquisas, as produções e reescritas coletivas, as discussões em sala de aula impregnam o sujeito e seu texto com as vozes dos "outros" - "a exterioridade está no interior do sujeito" (AUTHIER-REVUZ, 1990, p. 28). Essa interação, segundo Vygotski (apud LOUZADA, 1996, p. 144) é responsável pelo desenvolvimento dos indivíduos - é porque 0 indivíduo aprende coisas novas que ele se desenvolve. Não consideraremos, aqui, a hipótese das intervenções feitas por adultos na correção ou redação final do texto. Sabemos que o Prêmio, após a escolha dos textos semifinalistas, promove encontros com os alunos - autores dos textos - para realizar atividades de escrita, conforme informações contidas no site do concurso ${ }^{63}$, atitude que busca deixar evidente a lisura do concurso na escolha do vencedor.

As pesquisas realizadas junto a autores como Perelman (2005), Koch (2003) e Mosca (2004a) demonstraram que a argumentatividade está inscrita na própria língua. Schneuwly e Dolz (2004, p. 255) afirmam: "nossos próprios materiais

\footnotetext{
${ }^{63}$ Cf. site do Prêmio Escrevendo o Futuro: www.escrevendofuturo.org.br.
} 
confirmam que as crianças são, muito cedo, capazes de produzir intervenções que comportam uma tomada de posição sustentada por um argumento". Louzada (1996) mostrou que, nessa faixa de escolarização e desenvolvimento, as crianças já argumentam oralmente em defesa de suas opiniões, negociam pontos de vista com eventuais interlocutores, apresentando condições para uma aprendizagem mais consciente da argumentação. Esse mesmo fato se constata com as crianças produtoras dos textos de nosso corpus. Elas demonstraram que, submetidas a atividades - seqüência didática - para a aquisição do gênero "artigo de opinião", foram capazes de superar as estratégias argumentativas trabalhadas nas atividades [Cf. análise 3.2.2, p. 127]. O mesmo ocorre quanto à utilização, pelas crianças, de operadores que não foram trabalhados nas oficinas, como "já que" e "uma vez que", demonstrando, como vimos, que os alunos têm condições de reelaborar e reaplicar as noções assimiladas [Cf. análise 3.2.4, p. 144].

Com relação ao emprego dos tempos verbais, apesar de não terem sido trabalhados sistematicamente nas oficinas, concluímos, pelo levantamento feito, que a maioria dos alunos foi capaz de fazer o uso adequado dos verbos do mundo comentado, próprios do gênero argumentar, demonstrando conhecimento internalizado de usuários da língua.

Cabe, agora, uma reflexão sobre o ensino do gênero artigo de opinião para crianças de $4^{\underline{a}}$ e $5^{\underline{a}}$ séries. Buscaremos, novamente, os autores de Genebra. Eles sugerem um ensino dos gêneros em espiral, ampliando sua complexidade a cada ano, sem necessidade de repetir o ensino de um mesmo gênero, pois dentro de um agrupamento, multiplicam-se as possibilidades.

Com base nessas afirmações, sugerimos que os organizadores do concurso considerem a possibilidade de trabalhar o gênero "carta de solicitação" ou "carta de 
reclamação" com crianças do ensino fundamental I, por serem mais simples e mais próximas de seu universo. Elas igualmente permitiram desenvolver a competência argumentativa.

Sabemos que é intenção do Prêmio a organização de um concurso para as séries finais do ensino fundamental II, repetindo-se os mesmos agrupamentos de gêneros trabalhados na etapa do ensino fundamental I. Em função disso, gostaríamos de propor uma sugestão.

Cremos que seria mais apropriado o trabalho com artigo de opinião com alunos de $7^{\underline{a} \mathrm{~s}}$ e $8^{\underline{a} \mathrm{~s}}$ séries. Desse modo, não só se atenderia à complexidade própria da faixa etária dos jovens envolvidos, como também se poderia evitar a repetição do mesmo gênero, já que, com alunos do ensino fundamental I a escolha passaria a recair sobre a carta de solicitação e/ ou reclamação.

Outra consideração que fazemos é quanto à importância de instrumentalizar e apoiar o professor em sua tarefa. Afirmamos, no início de nossas considerações, que a maioria dos docentes ainda não modificou suas estratégias didáticas para o ensino da escrita e do oral. Isso se deve ao fato de muitos deles não terem sido orientados para a nova abordagem. Sentem-se mais seguros, aplicando as mesmas fórmulas a que foram submetidos nos bancos escolares. Schneuwly e Dolz (2004, p.273) asseveram ser primordial, em todos os momentos, na seqüência didática, o papel do professor, pois, como mediador, é ele o principal responsável pelo sucesso do trabalho desenvolvido.

Nesse sentido, o material do concurso revela eficiência na instrumentalização do professor, pois apresenta linguagem acessível, clareza nas explicações das atividades a serem desenvolvidas, além de procurar motivar o professor para que ele se mantenha envolvido durante a aplicação do projeto. Não restam dúvidas sobre a 
eficácia de seu papel em formar profissionais com condições de ensinar melhor a escrita por meio dos gêneros textuais e de seqüências didáticas.

No entanto, quanto a essas últimas, pensamos que deveriam se desdobrar em blocos de menor duração, o que as tornariam mais operacionais.

Nossa ressalva deve-se a fatores como desgaste e cansaço de professores e alunos, como comprovam os estudos dos autores franceses, por considerarmos longo demais o tempo necessário para a aplicação da seqüência, tal como o material do Prêmio propõe. Associamos a isso outra sugestão igualmente presente no material: a transcrição de textos na lousa, para leitura e análise. Ainda que conheçamos a limitação de meios em certos municípios do país - nos quais talvez nem existam máquinas de xérox -, julgamos que o tempo excessivo gasto com escrita de textos na lousa - dada a considerável extensão de alguns deles - exige um tempo que poderia ser dedicado a atividades propriamente lingüísticas.

Fundamental, ainda, seria refletir sobre o conteúdo dos textos fornecidos como exemplo para os alunos. É preciso verificar se apresentam tema relevante para a formação do cidadão e se a linguagem empregada é apropriada para crianças dessa faixa etária.

Quanto ao tema, consideramos pertinentes as escolhas dos textos ${ }^{64}$ de apoio: Sou contra a redução da maioridade penal de Renato Roseno, Trabalho infantil consome o futuro de muitas crianças de Jô Azevedo, A droga que é uma droga de Vera Meira Bestene, Meio ambiente $X$ direitos humanos de Sidney Grippi, Direito ao lazer de Anna Helena Altenfelder, ocorrendo o mesmo com os textos que compõem as oficinas, como Combate à dengue: uma responsabilidade de todos, de Neusa do Carmo Roldan entre outros.

\footnotetext{
${ }^{64}$ Os textos encontram-se em anexo.
} 
Não podemos dizer o mesmo de outro texto, muito bom, mas complexo demais para essa faixa etária. Trata-se de Depois da água, por que não o ar, de Antonio Ermírio de Moraes sobre taxa tributária, cujo tema não faz parte do universo infantil. Justificamos com exemplos: Em primeiro lugar, é preciso dizer que o Brasil tem uma péssima tradição em relação aos impostos e contribuições que incidem sobre o faturamento das empresas. Por exemplo, o Finsocial começou com uma alíquota de 0,5\%, que logo passou para 1,0\% [...]. E ainda: O segundo problema é que os recursos provenientes dessa taxa serão arrecadados para um fundo federal, para depois serem distribuídos aos municípios.

A escolha dos exemplos deveria considerar que as crianças participantes representam regiões de todo o país, o que nos faz crer que nem todas tenham acesso a jornais, revistas, periódicos, internet. Sabemos também que o desenvolvimento cognitivo dessa faixa etária interfere no entendimento do texto. A maneira como é trabalhado o tema, o grau de informatividade do texto e a adequação do nível de linguagem são pontos relevantes. O fragmento exemplificado acima servirá, novamente, a nossos propósitos. Acrescentamos outros: a) do texto $A$ droga que é uma droga de Vera Meira Bestene: A família, célula mater da sociedade, precisa estar sempre atenta, fazendo da informação e educação a aliada para que crianças [...] e Aos já dependentes não podemos deixar de prover a ajuda e o amparo emocional, procurando orientá-los a procurar apoio dos profissionais da saúde, do tratamento especializado, posto que a um tempo os pais e professores não têm mais a capacidade de controlar o problema; b) do texto Meio ambiente $X$ direitos humanos de Sidney Grippi: Dentre os fatores de sucesso para a melhoria da qualidade de vida das pessoas, o que pode ser entendido como sinônimo de cidadania ou simplesmente direitos humanos, está o processo da educação 
ambiental e A preservação dos elementos bióticos e abióticos dos ecossistemas, além dos recursos naturais, é indispensável para o equilíbrio [...].Não fazemos restrições ao texto Combate à dengue: uma responsabilidade de todos que compõe a oficina 9.

Acreditamos que esses exemplos sejam suficientes para uma reflexão sobre a questão. Por um lado, supondo a permanência do mesmo gênero em edições futuras, seria pertinente pensar em duas estratégias: a primeira seria buscar exemplos elaborados em linguagem mais próxima do universo dos alunos; a segunda, o levantamento das dificuldades presentes nos exemplos e a elaboração de atividades específicas. Por outro, caberia levantar, novamente, a hipótese de troca de gênero, sempre dentro do agrupamento dos argumentativos, como a carta de solicitação ou de reclamação.

As considerações e conclusões apresentadas evidenciam o valor sócioeducacional do Prêmio Escrevendo o Futuro, tanto por sua abrangência quanto pela oportunidade que tantos professores encontram de se atualizar e melhorar seu trabalho em sala de aula, oportunidade essa extensiva, também, a seus alunos que vivenciam novas estratégias para desenvolver sua competência lingüística. $O$ envolvimento da comunidade, além de fixar a posição de autor dos alunos, exerce um papel formador para todos os participantes que passarão a ver na língua um instrumento de inserção no grupo social. Nossas sugestões referem-se a questões pontuais e visam ao aprimoramento do prêmio que merece todo nosso respeito.

O ideal seria que todas as escolas aderissem a essa proposta, trabalhando 0 ensino de língua portuguesa com apoio nos gêneros do discurso e nas seqüências didáticas. Dessa maneira, é provável que abríssemos caminhos para mudar os 
resultados das estatísticas de testes regionais, nacionais e internacionais a que são submetidos nossos jovens. 


\section{REFERÊNCIAS BIBLIOGRÁFICAS}

ABREU, A. S. A arte de argumentar: gerenciando razão e emoção. 8. ed. São Paulo: Ateliê Editorial, 2005.

AMOSSY, Ruth.(Org.) Imagens de si no discurso: a construção do ethos.São Paulo: Contexto, 2005.

AUTHIER-REVUZ, J. Heterogeneidade(s) Enunciativa(s). Trad. Celene M.

Cruz e João Wanderley Geraldi. Campinas: Caderno de Estudos Lingüísticos. 1990. (Mimeog.)

BAKHTIN, M. Estética da criação verbal. 4. ed. São Paulo: Martins Fontes, 2003.

. Marxismo e filosofia da linguagem. 11. ed. São Paulo:Hucitec, 2004.

BECHARA, Evanildo. Moderna gramática portuguesa. 37.ed. rev. e ampl. Rio de Janeiro: Lucerna, 1999.

BORBA, Francisco da Silva. Introdução aos estudos lingüísticos. 11.ed. São Paulo : Pontes, 1991

BRAIT, B. (Org.). Bakhtin: conceitos-chave. São Paulo:Contexto,2005. . (Org.). Bakhtin: outros conceitos-chave. São Paulo: Contexto, 2006.

BRANDÃO, H. N. Escrita, Leitura, Dialogicidade. In: Bakhtin, Dialogismo e construção do sentido. BRAIT, B. (Org.) Campinas, SP.:Ed. Unicamp. (Mimeog.) [sd]

. Introdução à análise do discurso. 8. ed. Campinas, S.P.: Ed. Unicamp, 2002.

. Subjetividade, argumentação e polifonia: a propaganda da Petrobrás.São Paulo: Fundação Editora da UNES, 1998. 
BRASIL. Secretaria de Educação Fundamental. Parâmetros Curriculares Nacionais: terceiro e quarto ciclos do ensino fundamental: língua portuguesa. Brasília: MEC/ SEF. 1981.

BRONCKART, J. P. Atividade de linguagem, textos e discursos: por um interacionismo sócio-discursivo. São Paulo: EDUC, 2003.

BUENO, F. S. Dicionário escolar da língua portuguesa. 11. ed. Rio de Janeiro: FENAME, 1981.

CAMARA, Mattoso. Dicionário de lingüística e gramática : referente à língua portuguesa. 25. ed. Rio de Janeiro : Vozes, 2004.

CATACH, Nina. (org).Para uma teoria da língua escrita. Trad. de Fulvia M. L. Moretto e Guacira Marcondes Machado. São Paulo: Ática,1996.

CENPEC - Centro de Estudos e Pesquisas em Educação, Cultura e Ação Comunitária. Disponível em $<$ http/WWW3.WWW.cenpec.org.br/modules/xtconteúdo/index.php/?id=115. Acesso em: 7 ag. 2007.

CHARAUDEAU, P.; MAINGUENEAU. Dicionário de análise do discurso. Coord. da Trad. Fabiana Komesu. São Paulo: Contexto, 2004.

CUNHA, Celso, CINTRA, L. Nova gramática do português contemporâneo. 3.ed. Rio de Janeiro: Nova Fronteira, 2001.

DOLZ, J. \& PASQUIER. Enseignement de l'argumentation et retour sur lê texte. Repères no 10 . Université de Genève,1994. (Mimeogr.)

. Um decálogo para enseñar a escribir. In: Cultura y Educación, 2, p. 31-41. Madri: Infancia y aprendizaje. Trad. Roxane H. R. Rojo.1996. (Mimeogr.)

DUBOIS, Daniele e MONDADA, Lorenza. Construção dos objetos de discurso e categorização. Uma abordagem dos processos de referenciação. In: DUBOIS, D.; MONDADA, L. et alii. Referenciação. Org. Mônica Cavalcanti, Bernardete Rodrigues e Alena Ciulla. São Paulo: Contexto, 2003, p.17-52. 
FRANCHI, E. P. Pedagogia da alfabetização - da oralidade à escrita. São Paulo: Cortez,1988.

FERREIRA, Aurélio Buarque de Holanda. Novo Aurélio século XXI : o dicionário da língua portuguesa. 3 ed. Rio de Janeiro: Nova Fronteira, 1999.

GEE, James Paul. Oralidad y literacidad: de El Pensamento salvaje a Ways With words. In: Escritura y sociedad: nuevas teóricas y etnográficas. ZAVALA, Virginia; NIÑO- Murcia, Mercedes y AMES, Patrícia. (org.) Lima: Red para el Desarrollo de lãs Ciências Sociales em el Peru, 2004. (Mimeogr.)

GERALDI. J. W. (Org.) O texto na sala de aula - leitura e produção. Paraná: ASSOESTE, 1985.

Portos de passagem. São Paulo: Martins Fontes, 1997.

HOUAISS, Antônio. Dicionário Houaiss da língua portuguesa. Rio de Janeiro : Objetiva, 2001

ILARI, R. A lingüística e o ensino da língua portuguesa. São Paulo: Martins Fontes, 1986.

ITAÚ, FUNDAÇÃO SOCIAL/ CENPEC. Prêmio escrevendo o Futuro: kit Itaú de criação de textos, 2004.

ITAÚ, FUNDAÇÃO SOCIAL/ CENPEC. Prêmio Escrevendo o Futuro. Disponível em: $\underline{\text { WWW.escrevendoofuturo.org.br }}$

HUBNER, R. N. et al. (Org). Diário de classe 3 - Língua Portuguesa. São Paulo FDE, SE, 1998.

KALMAN, Judith. El acceso a la cultura escrita: la participación social y la apropiacion de conocimientos em eventos cotidianos de lectura y escritura. México: Revista Mexicana de Investigacion educativa, Vol. VIII, n 17, 2003.

$\mathrm{KOCH}$, Ingedore G. V. Argumentação e linguagem. 9.ed. São Paulo: Cortez, 2004a. 
.A coesão textual. 19. ed. São Paulo: Contexto, 2004b.

.A inter-ação pela linguagem. 9. ed. São Paulo: Contexto, 2004c.

; ELIAS, Vanda M. Ler e compreender: os sentidos do texto. 2. ed. São Paulo: Contexto, 2006.

O texto e a construção dos sentidos. 8. ed. São Paulo: Contexto, 2005.

; TRAVAGLIA, L. C. A coerência textual. 16. ed. São Paulo:Contexto, 2004d.

LOPES-ROSSI, M. A. G. (Org.) Gêneros discursivos no ensino de leitura e produção de textos. Taubaté, São Paulo: Cabral Editora e Livraria Universitária, 2002.

LOUZADA, M. S. O.Texto e contexto: um estudo de uma produção escrita em situação escolar. 1996. 246 f. São Paulo, Dissertação (Mestrado em Letras) Faculdade de Filosofia, Letras e Ciências Humanas, Universidade de São Paulo, S.P., 1996.

MAINGUENEAU, D. Análise de Textos de Comunicação. São Paulo: Cortez Cap XII "Polifonia, Discurso Direto", cap XIII "Discurso indireto, forma híbrida”, cap. XIV “Modalização autonímica, aspas, itálico”, 2001, p. 137-167.

Análise do Discurso. 2. ed. São Paulo: Pontes. Ed. Unicamp. Cap. 1 "A heterogeneidade mostrada", p. $75-107$. (Mimeog.) [sd]

Elementos de lingüística para o texto literário. São Paulo: Martins Fontes. Coleção Leitura e Crítica. Cap.1 “A situação de Enunciação”, 1996. (Mimeog.)

. Termos-chave da análise do discurso. Belo Horizonte: UFMG, 1998.

MACHADO, A. R. Ensino-aprendizagem de produção de textos na universidade: a descrição dos gêneros e a construção de material didático. Pontifícia Universidade Católica de São Paulo, 199-. (Mimeogr.) 
MARCUSCHI, L. A. Atividades de compreensão na interação verbal. In:

PRETI, Dino (Org). Estudos de língua falada: variações e confrontos. São

Paulo: Humanitas, 1999. Vol. 3.

. Gêneros textuais: definição e funcionalidade. In: DIONísıO, A.,

P.; Machado, A. R.; Bezerra, M. A.; (orgs.) Gêneros Textuais e Ensino. 3. ed. Rio de Janeiro: Lucerna, 2002.

O diálogo no contexto da aula expositiva: continuidade, ruptura e integração. In: PRETI, Dino (Org). Diálogos na fala e na escrita. São Paulo: Humanitas, 2005. VOL. 7.

MARTINS, N. S. Introdução à estilística. 3. ed. ver.aum. São Paulo: T. A. Queiroz, Editor, 2003.

MEYER, M. Questões de Retórica: Linguagem, Razão e Sedução. Lisboa, Edições 70, 1998. Cap. 4 "Retórica do sujeito, retórica dos sujeitos" e cap. 5 "Lógica do predador, Lógica do sedutor, Lógica do consenso", p. 105-154.

MOSCA, Lineide Salvador. A teoria perelmaniana e a questão da afetividade. In: OLIVEIRA Eduardo Chagas (org). Chäim Perelman: Direito e Retórica e Teoria da Argumentação. Feira de Santana: Universidade Estadual de Feira de Santana/ Núcleo Interdisciplinar de Estudos e Pesquisas em Filososfia, 2004a. p.129-140.

. (Org.) Discurso, argumentação e produção de sentido. São Paulo: Associação Editorial Humanitas, 2006.

A subjetividade no editorial: uma análise retórico-argumentativa da adjetivação.1990. 406 f. Tese de Doutorado - Universidade de São Paulo. São Paulo: DLCV, FFLCH, USP, S.P., 1990.

. Velhas e Novas Retóricas: convergências e desdobramentos. In: MOSCA, L.S. (org) Retóricas de Ontem e de Hoje. 3ed. São Paulo: Humanitas, 2004b, p. 17-54.

OLÉRON, Pierre. A argumentação. Lisboa. Publicações Europa-América, 1983.

[Orig. PUF], Cap. IV "Os diversos tipos de argumentos", p. 81-125. 
PEREIRA, Maria Luísa Álvares. Para uma didáctica textual (I). Tipos de textos/ tipos de discurso e ensino de Português. Aveiro: Universidade, 2001. (Mimeogr.)

PERELMAN, Chäim e OLBRECHT-TYTECA, L. 2. ed. L. O. Tratado da Argumentação. A Nova Retórica. São Paulo: Martins Fontes, 2005.

Retóricas. São Paulo, Martins Fontes, 2004.

ROCCO, M. T. F. Linguagem autoritária: televisão e persuasão. São Paulo: Editora Brasiliense,1989.

RODRIGUES, A., F. Como elaborar referência bibliográfica. 5. ed. rev. ampl. São Paulo: Associação Editorial Humanitas, 2005a.

Como elaborar citações e notas de rodapé. 2. ed. ampl. São Paulo: Associação Editorial Humanitas, 2005b.

ROJO, R. H. R. Interação em sala de aula e gêneros escolares do discurso: um enfoque enunciativo. Pontifícia Universidade Católica de São Paulo, 199-. (Mimeogr.)

Gêneros do discurso e gêneros textuais: questões teóricas e aplicadas. LAEL/ PUC - S.P., 200-. (Mimeogr.)

ROSAT, Marie-Claude; DOLZ, J.; SCHNEUWLY, B. E, no entanto...eles revisam! Efeitos de duas seqüências didáticas na reescrita de textos. FPSE, Université de Genève. [sd]. (Mimeogr.)

SCHNEUWLY, B.; DOLZ, J. Gêneros orais e escritos na escola. Campinas, S.P.: Mercado de Letras, 2004.

Gêneros e tipos de texto: considerações psicológicas e ontogenéticas. FPSE/ Université de Genève, 1994. (Mimeogr.)

SEVERINO, Antônio Joaquim. Metodologia do trabalho científico. 21. ed. rev. e ampl. São Paulo: Cortez, 2000. 
SILVA, L. A. Polidez na interação professor/ aluno. In: PRETI, Dino (Org.) Estudo da língua falada: variações e confrontos. São Paulo: Humanitas, 1999. Vol. 3

TANNEN, D; WALLAT, C. Enquadres interativos e esquemas de conhecimento em interação. In: RIBEIRO, B. T.; GARCEZ, P. M. (Org.) Sociolingüística interacional. 2.ed.rev. ampl. São Paulo: Loyola, 2002, p.183-214.

VAN DIJK, Teun A. Cognição, discurso e interação. 6. ed. São Paulo: Contexto, 2004.

. Discurso, conocimento e ideologia. Disponível em http://WWW. discourse.org. Acesso em: 22 abr. 2006a.

Discurso, notícia e ideologia. Estudos na Análise Crítica do Discurso. Porto: Campo das Letras, 2005.

The mass media today: discourses of domination or diversity?

Disponível em http://WWW. discourse.org. Acesso em: 20 maio 2006b

WEINRICH, H. (1964).Tempus . Besprochene und Erzähite Welt. Trad. Esp. de LATORRE, Frederico. Estructura y Función de los Tiempos em el Linguaje. Ed. Gredos, Madrid, 1974. Cap. III "Mundo comentado - mundo narrado", p. 60 - 94 e Cap.V. "El sistema metafórico temporal", 136-167.

WODAK, Ruth. Do que trata a ACD - Um resumo de sua história, conceitos Importantes e seus desenvolvimentos. Disponível em $<$ http//WWW3.unisul.br/paginas/ensino/pos/linguagem/revista/revista.html. Acesso em: 19 abr. 2006. 


\section{ANEXO 1 - Textos Semifinalistas do Pólo São Paulo}

*Os textos que compõem o corpus desta dissertação e o material de apoio do Prêmio Escrevendo o Futuro - 2004 poderão ser encontrados no trabalho escrito na Biblioteca da FFLCH da Universidade de São Paulo (21a․ CDD 372.6014 - 469. 798). 


\section{Apresentação dos Quadros}

Os quadros, a seguir, foram construídos com base no trabalho desenvolvido por Ingedore G. Villaça Koch , no livro Argumentação e Linguagem, com exceção do quinto quadro que analisou os tipos de argumentos utilizados pelos autores ${ }^{65}$.

O primeiro analisará os tempos verbais do discurso, conforme proposta desenvolvida por $\mathrm{H}$. Weinrich e adequadas ao português pela autora.

O segundo considerará os modalizadores que revelam a atitude do enunciador perante o enunciado que produz através de advérbios e expressões atitudinais e índices de avaliação.

O terceiro fará um levantamento dos operadores argumentativos utilizados para estabelecer a coesão do texto.

O quarto verificará as expressões que anunciam a posição do autor, a ocorrência do verbo dever, deôntico, a polifonia utilizada como argumento de autoridade com o objetivo de fortalecer o ponto de vista do autor, a voz do outro como contra-argumento e como consideração pela opinião do outro.

O quinto quadro buscará analisar os argumentos utilizados pelos alunosprodutores.

\footnotetext{
${ }^{65}$ Não foi utilizada a pontuação própria para retirada de fragmentos - aspas e reticências - pelo fato de termos a identificação do texto a que pertencem ao lado de cada quadro.
} 
ANEXO - 2

\begin{tabular}{|c|c|c|c|}
\hline \multicolumn{4}{|c|}{ Tempo Verbal } \\
\hline \multicolumn{4}{|c|}{ Atitude Comunicativa } \\
\hline Texto 9 & $\begin{array}{c}\text { MUNDO } \\
\text { COMENTADO }\end{array}$ & MUNDO NARRADO & $\begin{array}{c}\text { METÁFORA } \\
\text { TEMPORAL } \\
\text { (Validez limitada) }\end{array}$ \\
\hline & $\begin{array}{l}\text { I.22- pres. ind. refere } \\
\text { I.32- pres.ind.- } \\
\text { pensam, } \\
\text { escolhem, } \\
\text { desejam - (DD) } \\
\text { I.33- semitempo inf.- } \\
\text { ficar } \\
\text { I.35- pres.ind.- pensa, } \\
\text { conhece, sente } \\
\text { I.36- pres.ind.- odeia, } \\
\text { afeiçoa, sofre } \\
\text { I.37- pres.ind.- é, fala } \\
\\
\text { I.38- fut. pres. - } \\
\text { declarou, } \\
\text { estarão (DI) } \\
\text { I.41- pres. Ind.- vamos } \\
\text { I.41- semitempo inf.- } \\
\text { resgatar } \\
\text { I.42- semitempo inf.- } \\
\text { oferecer } \\
\text { I.46- pres.ind. tem } \\
\text { I.47- é } \\
\text { I.48- estão }\end{array}$ & $\begin{array}{l}\text { I.1- há - (passado) } \\
\text { I.2- pret. imp. ind - viviam } \\
\text { I.4- pret. imp. ind. ficavam } \\
\text { I.6- pret. imp. ind - eram } \\
\text { I.7- pret.ilmp. ind irritavam } \\
\text { I.8- pret. imp. ind achavam } \\
\text { I.8- semitempo inf. - } \\
\text { atormentar } \\
\text { I.10- pret. perf. ind -começou } \\
\text { I.10- pret. imp. ind- estava } \\
\text { I.10- semitempo part.- } \\
\text { abandonado } \\
\text { I.12- pret. imp. ind- foram } \\
\text { I.12- semitempo part.- } \\
\text { transferidos } \\
\text { I.16- pret. imp. ind - ficaram, } \\
\text { relacionaram } \\
\text { I.18- pret. imp. ind - estava } \\
\text { I.18- semitempo ger.- } \\
\text { interagindo } \\
\text { I.20- pret.perf. ind -começou } \\
\text { I.22- semitempo part.- } \\
\text { reconhecida } \\
\text { I.24- pret. perf. ind- descobriu } \\
\text { I.24- pret. imp. ind - queria } \\
\text { I.24- semitempo inf. - voltar } \\
\text { I.26- pret. perf. ind - foi } \\
\text { I.26- semitempo inf. - parar } \\
\text { I.27- pret.perf. ind enviou } \\
\text { I.28- semitempo ger.- } \\
\text { solicitando } \\
\text { I.29- fut. pret.- atenderia } \\
\text { I.29- semitempo inf- ficarem } \\
\text { I.30- semitempo part. - } \\
\text { situado } \\
\text { I.31- pret.perf. ind.- veio } \\
\text { I.34- fut. pret.- deveria } \\
\text { I.34- semitempo inf.- informar } \\
\text { I.44- pret.perf. ind. - voltaram } \\
\text { I.45- pret.perf. ind.- foi } \\
\text { I.50- semitempo inf.- resgatar, } \\
\text { livrar } \\
\text { I.50- fut. pret.- seria } \\
\text { I.51- tivessem } \\
\text { I.53- } 54-\text { fosse, pudesse } \\
\text { I.55- fut. pret.- voltariam } \\
\text { I.56- semitempo part. - feita } \\
\text { I.56- fut. pret.- deveria } \\
\text { I.56- semitempo inf. - } \\
\text { reformar }\end{array}$ & $\begin{array}{l}\text { I.20- } 22 \text { - começou/ refere } \\
\begin{array}{l}\text { I.34- } 37 \text { - deveria/ pensa, } \\
\text { conhece, sente, } \\
\text { odeia, afeiçoa, } \\
\text { é, é, fala } \\
\text { I.44-45 - voltaram, ficou/ } \\
\text { tem, é }\end{array}\end{array}$ \\
\hline
\end{tabular}




\begin{tabular}{|c|c|c|c|}
\hline \multicolumn{4}{|c|}{ Tempo Verbal } \\
\hline & & Atitude Comunicativa & \\
\hline Texto 32 & $\begin{array}{c}\text { MUNDO } \\
\text { COMENTADO }\end{array}$ & MUNDO NARRADO & $\begin{array}{c}\text { METÁFORA } \\
\text { TEMPORAL } \\
\text { (Validez Limitada) }\end{array}$ \\
\hline & $\begin{array}{l}\text { I.1- } \text { pres.ind.- vem } \\
\text { I.2- } \text { semitempo ger.- } \\
\text { sofrendo } \\
\text { I.2- semitempo part.- } \\
\text { criada } \\
\text { I.6- pres.ind.- sai } \\
\text { I.7- pres.ind.- é } \\
\text { I.8- pres.ind.- vai } \\
\text { I.8- semitempo inf.- } \\
\text { gerar } \\
\text { I.9- semitempo inf.- } \\
\text { ser } \\
\text { I.10- fut. pres. - terá } \\
\text { I.10- semitempo ger.- } \\
\text { abrigando } \\
\text { I.12- fut. pres.- } \\
\text { acarretará } \\
\text { I.15- pres.ind.- é } \\
\text { I.17- semitempo inf.- } \\
\text { falar } \\
\text { I.18- pres.ind.- é } \\
\text { I.20- pres.ind.- } \\
\text { acredita-se } \\
\text { I.20- fut. pres.- } \\
\text { mudarão } \\
\text { I.21- pres.ind.- é } \\
\text { I.22- semitempo- } \\
\text { pres.subj.-possa } \\
\text { I.22- semitempo inf.- } \\
\text { causar } \\
\text { I.24- pres.ind.- tem, } \\
\text { afasta } \\
\text { I.26- pres.ind.- há, } \\
\text { I.26- acreditam } \\
\text { I.27- sendo } \\
\text { I.28- fut. pres.- } \\
\text { tornará } \\
\text { I.28- pres.ind.- } \\
\text { propõem } \\
\text { I.29- semitempo- } \\
\text { pres.subj.-seja } \\
\text { I.29- semitempo part.- } \\
\text { construído } \\
\text { I.29- fut. pres.- será } \\
\text { I.30- pres.ind.- existe } \\
\text { I.32- pres.ind.- está } \\
\text { I.32- semitempo ger.- } \\
\text { ficando } \\
\text { I.32- pres.ind.- corre } \\
\text { I.32- semitempo inf.- } \\
\text { ver } \\
\text { I.33- semitempo ger.- } \\
\text { sendo } \\
\text { I.34- pres.ind.- tem } \\
\text { I.38- pres.ind.- pode }\end{array}$ & $\begin{array}{l}\text { I.1- há- passado } \\
\text { I.35- fut. pret.- seria } \\
\text { I.35- pret. perf. ind.- foi } \\
\text { I.36- pret. perf. ind.- } \\
\text { consagrou, fez }\end{array}$ & $\begin{array}{l}\text { I.31- } 36 \text { - está, corre-se, } \\
\text { tem/ seria, foi, consagrou, } \\
\text { fez }\end{array}$ \\
\hline
\end{tabular}




\begin{tabular}{|l|l|l|l|}
\hline Texto 32 & $\begin{array}{l}\text { I.38- semitempo inf.- } \\
\text { deixar } \\
\text { I.39- semitempo inf.- } \\
\text { parar }\end{array}$ & & \\
l.40- pres.ind.- é & & \\
I.40- semitempo inf.- & & \\
valorizar & & \\
l.41- pres.ind.- é & & \\
I.41- pres.ind.- faz & & \\
\hline
\end{tabular}




\begin{tabular}{|c|c|c|c|}
\hline \multicolumn{4}{|c|}{ Tempo Verbal } \\
\hline & & Atitude Comunicativa & \\
\hline Texto 71 & $\begin{array}{c}\text { MUNDO } \\
\text { COMENTADO }\end{array}$ & MUNDO NARRADO & $\begin{array}{c}\text { METÁFORA } \\
\text { TEMPORAL } \\
\text { (Validez limitada) }\end{array}$ \\
\hline & $\begin{array}{l}\text { I.1- pres.ind.- é } \\
\text { I.4- pres.ind.- há } \\
\text { I.6- pres.ind.- sou } \\
\text { I.8- } \text { semitempo ger.- } \\
\text { asfaltando } \\
\text { I.14- semitempo part.- } \\
\text { gerados } \\
\text { I.15- pres.ind.- são, } \\
\text { dificulta } \\
\text { I.16- pres.ind.- há } \\
\text { I.17- pres.ind.- há } \\
\text { I.20- pres.ind.- vão } \\
\text { I.20- semitempo ger.- } \\
\text { diminuindo } \\
\text { I.22- semitempo inf.- } \\
\text { chegar } \\
\text { I.31- pres.ind.- há } \\
\text { I.33- semitempo part.- } \\
\text { realizada } \\
\text { I.34- pres.ind.- é } \\
\text { I.35- semitempo ger.- } \\
\text { contando } \\
\text { I.36- pres.ind.- vivem } \\
\text { I.37- pres.ind.- são } \\
\text { I.37- semitempo ger.- } \\
\text { dizendo } \\
\text { I.38- pres.ind.- é } \\
\text { I.39- pres.ind.- } \\
\text { necessitam } \\
\text { I.40- pres.ind.- estão } \\
\text { I.40- semitempo ger.- } \\
\text { pensando } \\
\text { I.41. pres.ind.- } \\
\text { moramos } \\
\text { I.49- pres.ind.- há } \\
\text { I.50- pres.ind.- resta } \\
\text { I.51- semitempo- } \\
\text { pres.subj.- possam } \\
\text { I.51- semitempo inf.- } \\
\text { começar } \\
\text { I.53- pres.ind.- vivem } \\
\text { I.55- pres.ind.- estou } \\
\text { I.55- semitempo ger.- } \\
\text { pensando } \\
\text { I.56- fut. pres.- lutarei } \\
\text { I.56- semitempo- } \\
\text { pres.subj.- } \\
\text { tenhamos } \\
\text { I.57- fut. pres.- poderei } \\
\text { I.57- semitempo inf.- } \\
\text { dizer } \\
\text { I.58- pres.ind.- vivemos }\end{array}$ & $\begin{array}{l}\text { I.23- era } \\
\text { I.23- passar } \\
\text { I.25- era } \\
\text { I.25- possuindo } \\
\text { I.29- deixou } \\
\text { I.29- ser } \\
\text { I.29- usada } \\
\text { I.30- prejudicando } \\
\text { I.44- melhoraria } \\
\text { I.46- viriam } \\
\text { I.47- cresceria } \\
\text { I.53- seria } \\
\text { I.54- haveria }\end{array}$ & $\begin{array}{l}\text { I.9- } \begin{array}{c}\text { 12- poderiam ter, } \\
\text { haveria }\end{array} \\
\text { I.44- } 48 \text { - melhoraria, } \\
\text { viriam, cresceria } \\
\text { I.53- seria/ vivem/ haveria } \\
\text { I.58- poderei/ tive/vivemos }\end{array}$ \\
\hline
\end{tabular}




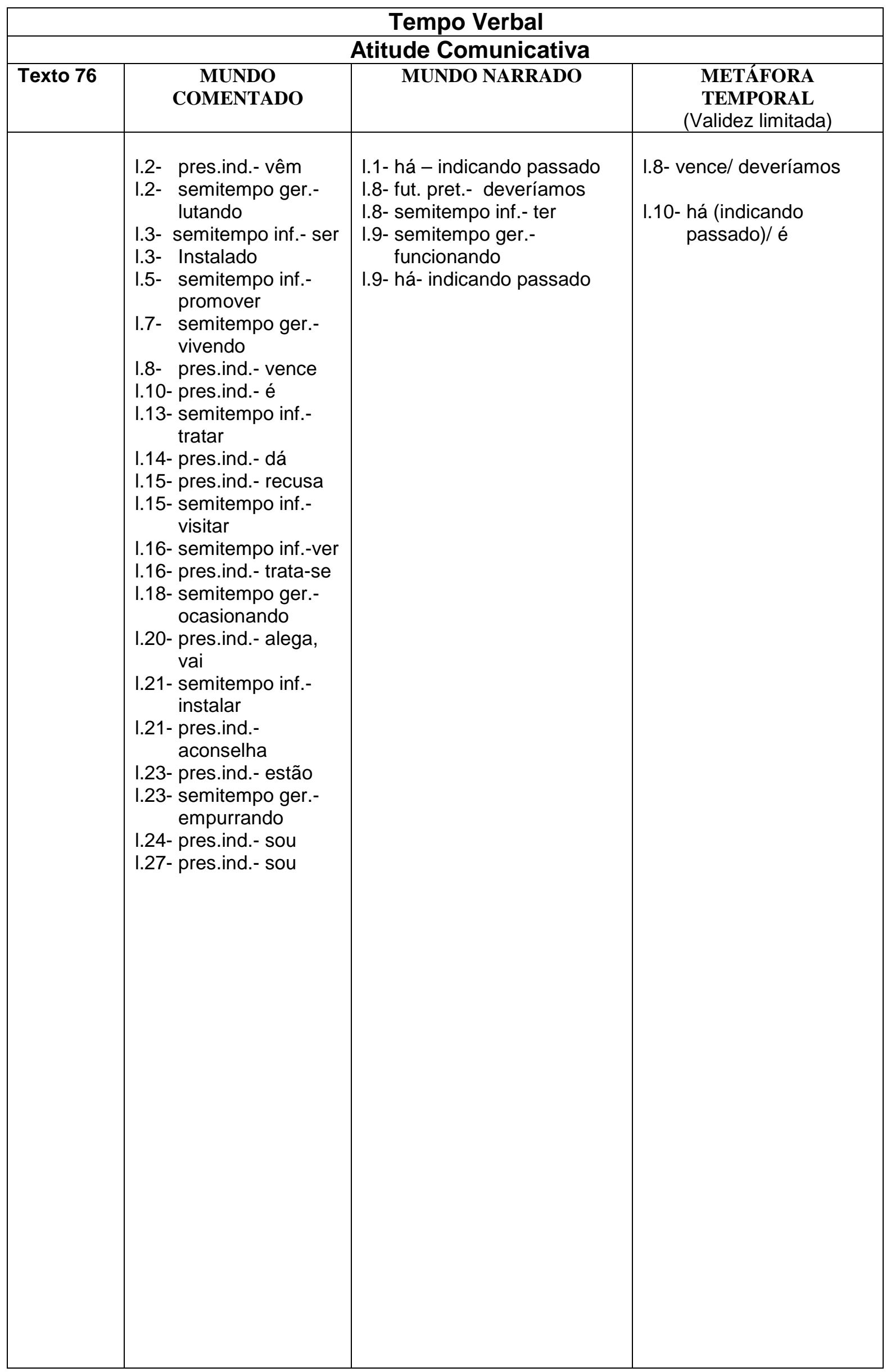




\begin{tabular}{|c|c|c|c|}
\hline \multicolumn{4}{|c|}{ Tempo Verbal } \\
\hline & & Atitude Comunicativa & \\
\hline Texto 89 & $\begin{array}{c}\text { MUNDO } \\
\text { COMENTADO }\end{array}$ & MUNDO NARRADO & $\begin{array}{c}\text { METÁFORA } \\
\text { TEMPORAL } \\
\text { (Validez limitada) }\end{array}$ \\
\hline & $\begin{array}{l}\text { I.12- pres.ind.- estão } \\
\text { I.13- pres.ind.- } \\
\text { consideram, está } \\
\text { I.15- pres.ind.- dizem, } \\
\text { I.16- pres.ind.- é, } \\
\text { dizem } \\
\text { I.18- pres.ind.- abre } \\
\text { I.18- solicitarem } \\
\text { I.19- pres.ind.- } \\
\text { fiquem } \\
\text { I.21- pres.ind.- são, } \\
\text { dizem } \\
\text { I.22- pres.ind.- é } \\
\text { I.23- semitempo inf.- } \\
\text { ser } \\
\text { I.23- semitempo part.- } \\
\text { usada } \\
\text { I.23- fut. pres.- será } \\
\text { I.23- utilizada } \\
\text { I.25- pres.ind.- penso } \\
\text { I.26- semitempo inf.- } \\
\text { acontecer } \\
\text { I.29- pres.ind.- é } \\
\text { I.30- pres.ind.- dá } \\
\text { I.32- pres.ind.- leva } \\
\text { I.35- pres.ind.- penso } \\
\text { I.38- pres.ind.- } \\
\text { acredito, é } \\
\text { I.40- pres.ind.- é } \\
\text { I.41- semitempo inf.- } \\
\text { garantirem } \\
\text { I.42- pres.ind.- é, } \\
\text { está } \\
\text { I.45- pres.ind.- é } \\
\text { I.46- pres.ind.- vive } \\
\text { I.47- pres.ind.- sou } \\
\text { I.48- pres.ind.- } \\
\text { concordo, dizem } \\
\text { I.49- pres.ind.- } \\
\text { falaram }\end{array}$ & $\begin{array}{l}\text { I.1- pret. perf. ind aconteceu } \\
\text { I.2- pret. perf. ind interditou } \\
\text { I.4- semitempo ger.- } \\
\text { provocando } \\
\text { I.5- pret. perf. ind pediu } \\
\text { I.6- semitempo ger.- alegando } \\
\text { I.6- pret. imp. ind - estava } \\
\text { I.8- pret. perf. ind foi } \\
\text { I.8- pret. imp. ind - possuía } \\
\text { I.10- semitempo- pret. imp. } \\
\text { subj.- } \\
\text { cedesse } \\
\text { I.10- fut. pret.- teria } \\
\text { I.10- semitempo inf.- parar } \\
\text { I.11- semitempo inf.- demitir } \\
\text { I.15- pret. perf. ind agiu } \\
\text { I.17- pret. perf. ind - } \\
\text { atrapalhou } \\
\text { I.18- pret. perf. ind foi } \\
\text { I.18- semitempo part.- } \\
\text { avisada } \\
\text { I.21- pret. perf. ind impediu } \\
\text { I.25- pret. imp. ind - havia } \\
\text { I.27- pret. perf. ind foi } \\
\text { I.27- semitempo part.- } \\
\text { comunicada } \\
\text { I.33- fut. pret.- deveria } \\
\text { I.33- semitempo inf.- estar } \\
\text { I.33- semitempo ger.-sendo } \\
\text { I.34- semitempo part.- usada } \\
\text { I.35- fut. pret.- deveria } \\
\text { I.35- semitempo inf.- ter } \\
\text { I.35- semitempo part.- } \\
\text { construído } \\
\text { I.36- semitempo inf.- secar, } \\
\text { tentar, } \\
\text { encontrar } \\
\text { I.37- semitempo inf.- } \\
\text { incomodar } \\
\text { I.39- pret. perf. ind foi } \\
\text { I.44- pret. perf. ind afirmou }\end{array}$ & 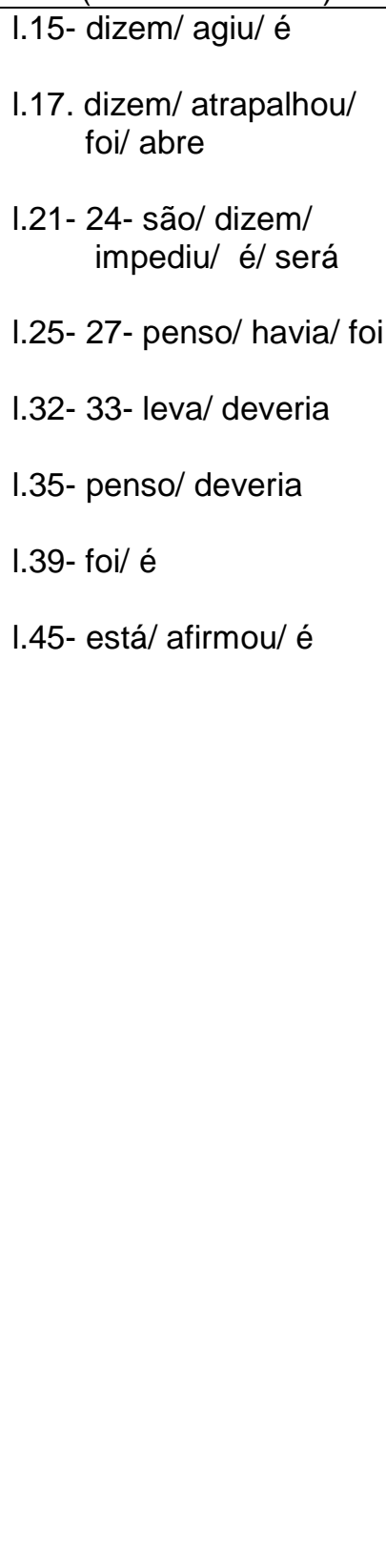 \\
\hline
\end{tabular}




\begin{tabular}{|c|c|c|c|}
\hline \multicolumn{4}{|c|}{ Tempo Verbal } \\
\hline & & Atitude Comunicativa & \\
\hline Texto 128 & $\begin{array}{c}\text { MUNDO } \\
\text { COMENTADO }\end{array}$ & MUNDO NARRADO & $\begin{array}{c}\text { METÁFORA } \\
\text { TEMPORAL } \\
\text { (Validez limitada) }\end{array}$ \\
\hline & $\begin{array}{l}\text { I.1- pres.ind.- é } \\
\text { I.1- considerada } \\
\text { I.2- pres.ind.- vem } \\
\text { I.5- pres.ind.- é } \\
\text { I.13- pres.ind.- evitam } \\
\text { I.14- pres.ind.- } \\
\text { podem } \\
\text { I.14- semitempo inf.- } \\
\text { tirar } \\
\text { I.16- pres.ind.- } \\
\text { afirmam } \\
\text { I.16- semitempo inf.- } \\
\text { ser } \\
\text { I. 17-pres.ind.- é } \\
\text { I.17- semitempo ger.- } \\
\text { dizendo } \\
\text { I.18- pres. ind.- } \\
\text { perdem } \\
\text { I.18- semitempo ger.- } \\
\text { esperando } \\
\text { I.18- semitempo inf.- } \\
\text { abrir } \\
\text { I.19- pres.ind.- é } \\
\text { I.19- semitempo inf.- } \\
\text { usar } \\
\text { I.21- pres.ind.- } \\
\text { andam } \\
\text { I.22- pres.ind.- } \\
\text { intimidam } \\
\text { I.28- pres.ind.- penso } \\
\text { I.28- semitempo- } \\
\text { pret. imp. subj.- } \\
\text { houvesse } \\
\text { I.30- pres.ind.- sou, } \\
\text { vejo } \\
\text { I.31- semitempo ger.- } \\
\text { oferecendo }\end{array}$ & $\begin{array}{l}\text { I.6- pret. perf. ind.- colocou } \\
\text { I.8- pret. imp. ind - era } \\
\text { I.9- pret. perf. ind.- mandou } \\
\text { I.9- semitempo inf.- retirá-lo } \\
\text { I.10- pret. perf. ind reinstalou, } \\
\text { instalou } \\
\text { I.12- pret. perf. ind.- foram } \\
\text { I.24- pret. imp. ind - } \\
\text { diminuíram } \\
\text { I.25- há- indicando passado } \\
\text { I.25- pret. perf. ind.- } \\
\text { aconteceu } \\
\text { I.27- pret. perf. ind.- morreu } \\
\text { I.28- pret. imp. ind - ia } \\
\text { I.28- semitempo ger.- saindo } \\
\text { I.28- fut. pret.- teria } \\
\text { I.29- semitempo part.- } \\
\text { acontecido }\end{array}$ & $\begin{array}{l}\text { I.5-10- é/ colocou } \\
\text { mandou, reinstalou } \\
\text { I.12-13- foram/ evitam }\end{array}$ \\
\hline
\end{tabular}




\begin{tabular}{|c|c|c|c|}
\hline \multicolumn{4}{|c|}{ Tempo Verbal } \\
\hline & & Atitude Comunicativa & \\
\hline Texto 130 & $\begin{array}{c}\text { MUNDO } \\
\text { COMENTADO }\end{array}$ & MUNDO NARRADO & $\begin{array}{c}\text { METÁFORA } \\
\text { TEMPORAL } \\
\text { (Validez limitada) }\end{array}$ \\
\hline & $\begin{array}{l}\text { I.1- pres.ind.- abriga } \\
\text { I.2- pres.ind.- está } \\
\text { I.2- semitempo ger.- } \\
\text { passando } \\
\text { I.5- pres. ind.dizem } \\
\text { I.8- pres.ind.- sou } \\
\text { I.9- pres.ind.- está } \\
\text { I.9- semitempo ger.- } \\
\text { saindo } \\
\text { I.10- semitempo inf.- } \\
\text { fazer } \\
\text { I.11- semitempo inf.- } \\
\text { tapar, investir } \\
\text { I.12- pres.ind.- } \\
\text { constroem } \\
\text { I.12- fut. pres.- serão } \\
\text { I.15- pres.ind.- são } \\
\text { I.18- pres.ind.- dizem } \\
\text { I.18- fut. pres.- haverá } \\
\text { I.19- fut. pres.- irão } \\
\text { I.19- semitempo inf.- } \\
\text { reformar } \\
\text { I.20- semitempo inf.- } \\
\text { trazer } \\
\text { I.20- pres.ind.- dizem } \\
\text { I.21- fut. pres.- será } \\
\text { I.21- pres.ind.- é } \\
\text { I.22- machucarem } \\
\text { I.23- pres.ind.- penso } \\
\text { I.23- fut. pres.- } \\
\text { aumentará } \\
\text { I.23- pres.ind.- há } \\
\text { I.24- pres.ind.- } \\
\text { precisam } \\
\text { I.25- semitempo inf.- } \\
\text { pagar } \\
\text { I.26- trabalharem } \\
\text { I.26- fut. pres.- } \\
\text { precisarão } \\
\text { I.26- semitempo inf.- } \\
\text { pagar } \\
\text { I.27- fut. pres.- será } \\
\text { I.30- pres.ind.-servem } \\
\text { I.33- pres.ind.- está } \\
\text { I.37- pret. perf. comp.- } \\
\text { tenha dito } \\
\text { I.37- semitempo ger.- } \\
\text { afirmando } \\
\text { I.39- pres.ind.- tinham } \\
\text { I.39- semitempo inf.- } \\
\text { pensar } \\
\text { I.41- pres.ind.digo,brinca }\end{array}$ & $\begin{array}{l}\text { I.5- } \text { pret. imp. ind - estava } \\
\text { I.5- } \quad \text { semitempo ger.- } \\
\text { precisando } \\
\text { I.6- pret. imp. ind - era } \\
\text { I.9- pret. perf. ind.- passou } \\
\text { I.10- pret. imp. ind - era } \\
\text { I.14- pret. perf. ind.- trouxe } \\
\text { I.16- fut. pret.- poderiam } \\
\text { I.16- semitempo inf.- fazer } \\
\text { I.17- semitempo- pret. imp. } \\
\text { subj.- fossem } \\
\text { I.28- pret. imp.- sentavam-se }\end{array}$ & $\begin{array}{l}\text { I.5- dizem/ estava, era } \\
\text { I.9- } 10 \text { - está/ passou, era }\end{array}$ \\
\hline
\end{tabular}




\begin{tabular}{|c|c|c|c|}
\hline \multicolumn{4}{|c|}{ Tempo Verbal } \\
\hline & & Atitude Comunicativa & \\
\hline Texto 201 & $\begin{array}{c}\text { MUNDO } \\
\text { COMENTADO }\end{array}$ & MUNDO NARRADO & $\begin{array}{l}\text { METÁFORA } \\
\text { TEMPORAL } \\
\text { (Validez limitada) }\end{array}$ \\
\hline & $\begin{array}{l}\text { I.1- } \text { pres.ind.- é } \\
\text { I.2- pres.ind.- há } \\
\text { I.5- pres.ind.- existem } \\
\text { I.6- pres.ind.- incluem } \\
\text { I.7- pres.ind.- } \\
\text { necessitam } \\
\text { I.9- } \text { semitempo- pres. } \\
\text { subj.- possam } \\
\text { I.9- semitempo inf.- } \\
\text { levar, brincar } \\
\text { I.10- semitempo inf.- } \\
\text { refletir, jogar, } \\
\text { conversar, passear } \\
\text { I.14- pres.ind.- estão } \\
\text { I.14- semitempo ger.- } \\
\text { investindo } \\
\text { I.17- pres.ind.- } \\
\text { precisamos } \\
\text { I.21- pres.ind.- penso } \\
\text { I.21- semitempo ger.- } \\
\text { agindo } \\
\text { I.23- pres.ind.- há, } \\
\text { concordam } \\
\text { I.23- semitempo inf.- } \\
\text { gastar } \\
\text { I.24- pres.ind.- dizem, } \\
\text { há } \\
\text { I.26- pres.ind.- podem } \\
\text { I.26- semitempo inf.- } \\
\text { pagar } \\
\text { I.27- semitempo inf.- ir } \\
\text { I.29- pres.ind.- } \\
\text { concordo } \\
\text { I.29- semitempo inf.- } \\
\text { pensar } \\
\text { I.32- pres.ind.- sou } \\
\text { I.34- fut. pres.- será, } \\
\text { ganhará }\end{array}$ & $\begin{array}{l}\text { I.12- fut. pret.- deveriam } \\
\text { l.12- semitempo inf.- investir } \\
\text { I.19- fut. pret.- trocariam } \\
\text { I.20- fut. pret.- estariam } \\
\text { l.21- fut. pret.- diminuiria } \\
\text { l.30- fut. pret.- deveriam } \\
\text { I.30- semitempo inf.- } \\
\text { colaborar, } \\
\quad \text { ter }\end{array}$ & $\begin{array}{l}\text { I.17-20- precisamos/ } \\
\text { trocariam, estariam } \\
\text { I.21- penso/ diminuiria } \\
\text { I.29-30- concordo/ } \\
\text { deveriam }\end{array}$ \\
\hline
\end{tabular}


ANEXO 3

\begin{tabular}{|c|c|c|}
\hline Texto 9 & $\begin{array}{c}\text { Advérbios e expressões } \\
\text { atitudinais }\end{array}$ & Índices de Avaliação \\
\hline & I.17- principalmente & I.5 - jaula fria e malcheirosa \\
\hline & & $\begin{array}{l}\text { I.8 - o público muitas vezes achavam graça } \\
\text { em atormentá-los ( sic) }\end{array}$ \\
\hline & & I.17- se relacionam muito bem \\
\hline & & I.31- a resposta veio com ironia \\
\hline & & I.34- deveria se informar melhor \\
\hline & & $\begin{array}{l}\text { I.40 - estarão em melhores condições } \\
\text { (outra voz) }\end{array}$ \\
\hline & & I.45- ficou uma beleza \\
\hline & & I.48- q ue estão bem \\
\hline & & I.51- para que tivessem uma vida digna \\
\hline & & I.53- se a população fosse melhor informada \\
\hline & & $\begin{array}{l}\text { I.56- reformar conceitos mesquinhos e } \\
\text { egoístas de muitas pessoas }\end{array}$ \\
\hline
\end{tabular}

\begin{tabular}{|l|l|l|}
\hline Texto 32 & \multicolumn{1}{|c|}{$\begin{array}{c}\text { Advérbios e expressões } \\
\text { atitudinais }\end{array}$} & \multicolumn{1}{c|}{ Índices de Avaliação } \\
\hline & I.24- definitivamente (outra voz) & I.7- a importância dessa obra \\
\hline & I.27- totalmente (outra voz) & I.12- acarretará uma melhora na economia \\
\hline & & $1.14-$ Outro ponto não menos importante \\
\hline & & $1.21-$ o jogador e conhecido e admirado \\
\hline & & $1.27-$ a obra o tornará mais restrito (outra voz) \\
\hline & & $1.30-$ será que existe área melhor do que esta? \\
\hline & & $1.35-$ isso seria uma injustiça \\
\hline
\end{tabular}

\begin{tabular}{|l|l|l|}
\hline Texto 71 & \multicolumn{1}{|c|}{$\begin{array}{c}\text { Advérbios e expressões } \\
\text { atitudinais }\end{array}$} & \multicolumn{1}{c|}{ Índices de Avaliação } \\
\hline & & $1.4-$ há poucos habitantes e o maior problema \\
\hline & & $1.10-$ melhoria no transporte \\
\hline & & $1.15-$ dificulta o transporte \\
\hline & & $1.44-$ a pavimentação melhoria e muito a vida \\
\hline & & 1.53 - seria de grande importância \\
\hline & & 1.58 - tive o prazer de fazer algo \\
\hline
\end{tabular}




\begin{tabular}{|c|c|c|}
\hline Texto 76 & $\begin{array}{c}\text { Advérbios e expressões } \\
\text { atitudinais }\end{array}$ & Índices de Avaliação \\
\hline & & I.5- promover uma maior segurança \\
\hline & & I.10- o número é muito maior do que \\
\hline & & I.13 - não dá a atencão necessária \\
\hline & & $\begin{array}{l}\text { I.16- muito movimentada e com cruzamento } \\
\text { perigoso }\end{array}$ \\
\hline
\end{tabular}

\begin{tabular}{|c|c|c|}
\hline Texto 89 & $\begin{array}{l}\text { Advérbios e expressões } \\
\text { atitudinais }\end{array}$ & Índices de Avaliação \\
\hline & I.24 - aproximadamente(outra voz) & I.1- fato bastante estranho \\
\hline & & I.12- alqumas pessoas estão revoltadas \\
\hline & & $\begin{array}{l}\text { I.25- havia a possibilidade de acontecer } \\
\text { acidentes }\end{array}$ \\
\hline & & I.30- é uma das mais movimentadas \\
\hline & & 1.37- encontrar outra solucão sem incomodar \\
\hline & & $\begin{array}{l}\text { I.46- Pelo jeito minha cidade ainda vive no } \\
\text { tempo dos coronéis }\end{array}$ \\
\hline & & I.49- e o dinheiro falaram mais alto nesse caso \\
\hline
\end{tabular}

\begin{tabular}{|l|l|l|}
\hline Texto 128 & \multicolumn{1}{|c|}{$\begin{array}{c}\text { Advérbios e expressões } \\
\text { atitudinais }\end{array}$} & \multicolumn{1}{c|}{ Índices de Avaliação } \\
\hline & I.20- geralmente & I.1- é considerada uma cidade pequena \\
\hline & I.24- atualmente & $\begin{array}{c}\text { I.13- foram uma boa idéia pois evitam graves } \\
\text { acidentes }\end{array}$ \\
\hline & & I.21- andam muito apressados \\
\hline & & $\begin{array}{l}\text { I.22- dando mais organização } \\
\text { I.24- acidentes com automóveis diminuíram } \\
\text { muito }\end{array}$ \\
\hline & & $\begin{array}{l}\text { I.26- aconteceu um fato lamentável } \\
\text { I.31- um ótimo investimento, ofereceram mais } \\
\text { segurança }\end{array}$ \\
\hline
\end{tabular}

\begin{tabular}{|l|l|l|}
\hline Texto $\mathbf{1 3 0}$ & \multicolumn{1}{|c|}{$\begin{array}{c}\text { Advérbios e expressões } \\
\text { atitudinais }\end{array}$} & \multicolumn{1}{c|}{ Índices de Avaliação } \\
\hline & I.8- particularmente & $1.5-$ era feia e suja (outros achavam) \\
\hline & & $1.9-$ está saindo muito cara (outra voz) \\
\hline & & 1.12 - que não serão úteis \\
\hline & & 1.17 - por um preço menor \\
\hline & & 1.24 - há muito comércio em volta dela \\
\hline & & $\begin{array}{c}1.40 \text { - Temos outras necessidades (...) muito } \\
\text { mais urgentes }\end{array}$ \\
\hline
\end{tabular}




\begin{tabular}{|c|c|c|}
\hline Texto 201 & $\begin{array}{l}\text { Advérbios e expressões } \\
\text { atitudinais }\end{array}$ & Índices de Avaliação \\
\hline & & I.3 - grande quantidade de casa \\
\hline & & 1.5 - muitos moradores \\
\hline & & I.12 - investir mais nos bairros \\
\hline & & I.13 - classe mais baixa \\
\hline & & I.14 - quantidade maior de dinheiro \\
\hline & & I.15 - grandes avenidas \\
\hline & & $\begin{array}{l}\text { I.17 - lugar que seja grande, bonito (...) muito] } \\
\text { conforto }\end{array}$ \\
\hline & & $\begin{array}{l}1.20 \text { - as ruas que são perigosas(...)mais } \\
\text { seguros }\end{array}$ \\
\hline & & 1.26 - elas podem pagar o alto custo \\
\hline & & $\begin{array}{l}\text { I.29 - pensar dessa forma egoísta(...) } \\
\text { comunidade melhor }\end{array}$ \\
\hline & & I.34 - será mais valorizado e ganhará mais vida \\
\hline
\end{tabular}




\begin{tabular}{|c|c|c|}
\hline Texto & Posicionamento do autor & $\begin{array}{l}\text { Dever - Deôntico } \\
\text { (Modalidade deôntica: refere-se ao eixo da } \\
\text { conduta, demonstra tomada de posição do } \\
\text { autor) }\end{array}$ \\
\hline 9 & $\begin{array}{l}\text { I.50- Na minha opinião } \\
\text { I.53- Eu penso que }\end{array}$ & $\begin{array}{l}\text { I.34- O senhor prefeito deveria se } \\
\text { informar melhor } \\
\text { I.56- E essa reforma deveria servir para } \\
\text { reformar os conceitos mesquinhos }\end{array}$ \\
\hline 32 & & $\begin{array}{l}\text { I.38- Não se deve deixar que o acervo (...) } \\
\text { vá para em outro lugar }\end{array}$ \\
\hline 71 & $\begin{array}{l}\text { I.6- Eu sou favorável } \\
\text { I.40- Na minha opinião } \\
\text { I.55- Eu estou pensando no } \\
\text { meu futuro }\end{array}$ & \\
\hline 76 & $\begin{array}{l}\text { I.23 - A meu ver } \\
\text { I.24 - Sou a favor } \\
\text { I.26 - sou favorável }\end{array}$ & $\begin{array}{l}\text { I.8 - nós deveríamos ter um } \\
\text { semáforo }\end{array}$ \\
\hline 89 & $\begin{array}{l}\text { I.25 - Eu penso que } \\
\text { I.35 - Penso ainda que } \\
\text { l.38 - acredito que } \\
\text { I.47 - sou contra } \\
\text { l.48 - e concordo com } \\
\text { aqueles que dizem }\end{array}$ & $\begin{array}{l}\text { I.33 - não deveria estar sendo } \\
\text { usada dessa forma } \\
\text { I.35 - o fazendeiro deveria ter construído } \\
\text { outros terreiros }\end{array}$ \\
\hline 128 & $\begin{array}{l}\text { I.12 - Na minha opinião } \\
\text { I.28 - Penso que } \\
\text { I.30 - eu sou favorável } \\
\text { I.30 - e o vejo como }\end{array}$ & \\
\hline 130 & $\begin{array}{l}\text { I.3 - Particularmente sou } \\
\text { contra } \\
\text { I.16 - Na minha opinião } \\
\text { I.23 - penso que } \\
\text { I.38 - no meu ponto de vista } \\
\text { I.41 - Por isso eu digo }\end{array}$ & \\
\hline 201 & $\begin{array}{l}\text { I.21- penso que } \\
\text { l.29-Eu não concordo } \\
\text { I.32-eu sou favorável }\end{array}$ & $\begin{array}{l}\text { I.12 - Os políticos deveriam investir mais } \\
\text { I.30 - Todos deveriam colaborar }\end{array}$ \\
\hline
\end{tabular}


ANEXO - 5

\begin{tabular}{|c|c|c|c|c|c|c|}
\hline \multicolumn{7}{|c|}{1 - OPERADORES ARGUMENTATIVOS } \\
\hline Texto & 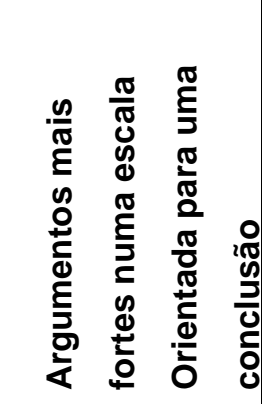 & 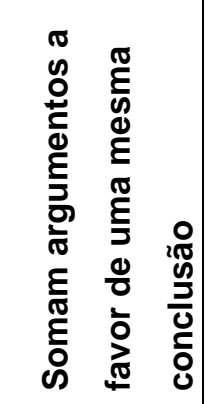 & 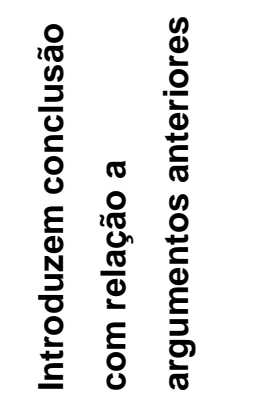 & 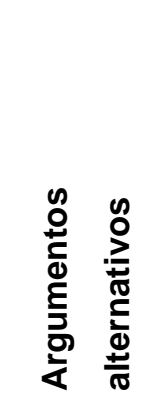 & 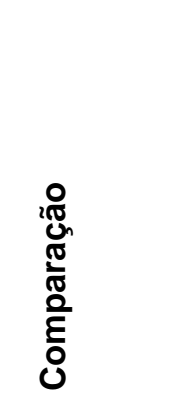 & 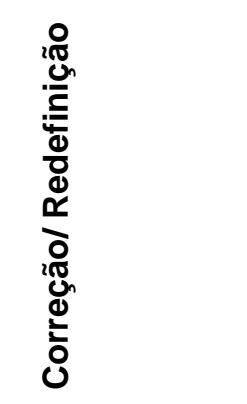 \\
\hline 9 & $\begin{array}{l}\text { I.38- mesmo } \\
\text { I.46- até }\end{array}$ & $\begin{array}{l}.16-\mathrm{e} \\
1.27-\mathrm{e} \\
1.30- \\
\text { também } \\
1.52-\mathrm{e} \\
1.54-\mathrm{e} \\
1.56-\mathrm{e}\end{array}$ & & & & \\
\hline 32 & I.33- até mesmo & $\begin{array}{l}\mathrm{l} .10-\text { ainda } \\
\mathrm{l} .14- \\
\quad \text { também } \\
\mathrm{I} .26-\text { ainda } \\
\mathrm{I} .32-\mathrm{e} \\
\mathrm{I} .36-\mathrm{e} \\
\mathrm{I} .41-\mathrm{e}\end{array}$ & 1.29 - então & 1.30- ou & $\begin{array}{l}\text { I.30- } \\
\text { melhor do } \\
\text { que } \\
\text { I.14- não } \\
\text { menos }\end{array}$ & I.35 - ou melhor \\
\hline 71 & I.22 - até & $\begin{array}{l}.5-\mathrm{e} \\
\mathrm{l} .10-\mathrm{e} \\
\mathrm{l} .12-\mathrm{e} \\
\mathrm{I} .16-\mathrm{e} \\
\mathrm{I} .38-\mathrm{e} \\
\mathrm{I} .42-\mathrm{e} \\
\mathrm{I} .45-\text { além } \\
\quad \text { disso } \\
\mathrm{I} .48- \\
\quad \text { também } \\
\mathrm{I} .50-\mathrm{e} \\
\mathrm{I} .57-\mathrm{e}\end{array}$ & $\begin{array}{l}\mathrm{l} .12-\text { assim } \\
\mathrm{l} .52-\quad \text { portanto } \\
\mathrm{l} .56-\text { por isso }\end{array}$ & & & \\
\hline 76 & & $\begin{array}{l}\text { I.26- como } \\
\text { também }\end{array}$ & I.27- logo & & $\begin{array}{l}\text { I.10- maior } \\
\text { do que }\end{array}$ & \\
\hline
\end{tabular}




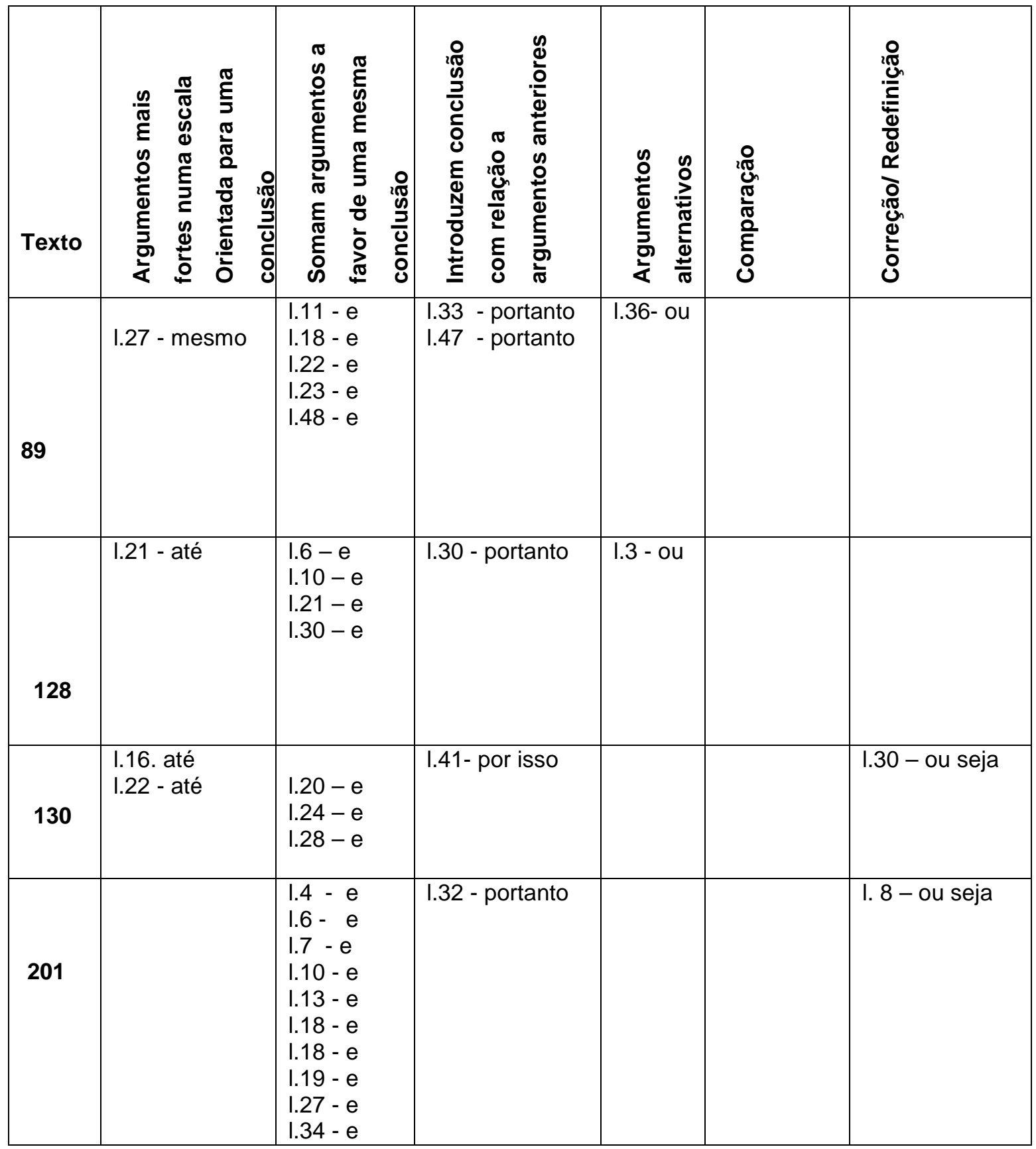




\begin{tabular}{|c|c|c|c|c|c|}
\hline \multicolumn{6}{|c|}{2 - OPERADORES ARGUMENTATIVOS } \\
\hline Texto & 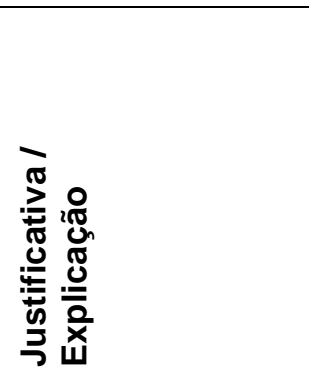 & 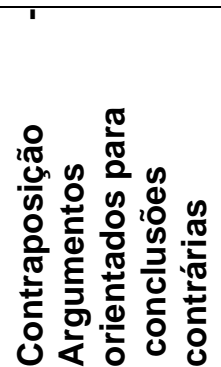 & 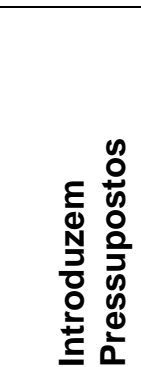 & 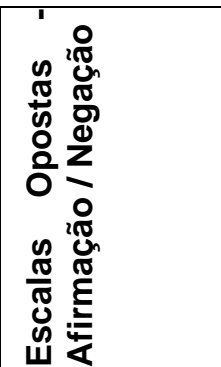 & 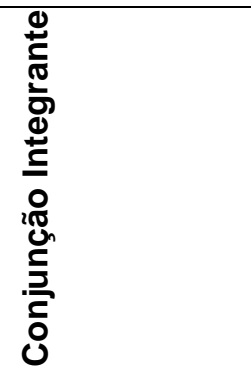 \\
\hline 9 & $\begin{array}{l}\text { l.4-que } \\
\text { l. } .7 \text { - que } \\
\text { l.10 - que } \\
\text { l.18 - que } \\
\text { l.22 - que } \\
\text { l.35 - pois } \\
\text { l.44 - que } \\
\text { l.47 - que } \\
\text { l.48 - que }\end{array}$ & I.48 - mas & & & $\begin{array}{l}1.24-\text { que } \\
1.28-\text { se } \\
1.37-q u e \\
1.39-\text { que } \\
1.53-\text { que }\end{array}$ \\
\hline 32 & $\begin{array}{l}\text { I.8 - pois } \\
\text { I.8 - uma vez que } \\
\text { I.14 - que } \\
\text { I.18 - que } \\
\text { I.20 - já que } \\
\text { I.24 - pois } \\
\text { I.27 - pois } \\
\text { I.35 - já que } \\
\text { I.36 - que } \\
\text { I.39 - que } \\
\text { I.41 - que }\end{array}$ & I.29- mas & $\begin{array}{l}\text { I.31- já } \\
\text { I.34 - já }\end{array}$ & $\begin{array}{l}\text { I.19 } \\
\text { apenas }\end{array}$ & $\begin{array}{l}\text { I.20 - que } \\
\text { l.22 - que } \\
\text { l.29 - que/ que } \\
\text { l.36 - que }\end{array}$ \\
\hline 71 & $\begin{array}{l}1.8 \text { - pois } \\
\text { l.41 - que } \\
\text { l.53 - que } \\
\text { I.54 - porque } \\
\text { I.58 - que }\end{array}$ & & & $\begin{array}{l}\text { I.4 -poucos } \\
\text { I.31 apenas } \\
\text { I.5o- - só }\end{array}$ & $\begin{array}{l}.38-q u e \\
\text { I.38-que } \\
\text { I.57-que }\end{array}$ \\
\hline 76 & $\begin{array}{l}\text { I.9 - pois } \\
\text { I.14- uma vez que }\end{array}$ & & I.9- já & & 1.20 que \\
\hline
\end{tabular}




\begin{tabular}{|c|c|c|c|c|c|}
\hline Texto & 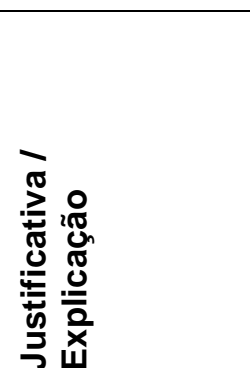 & 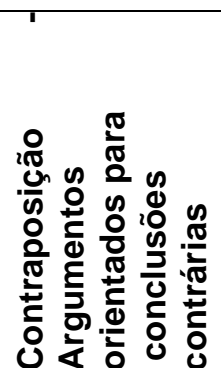 & 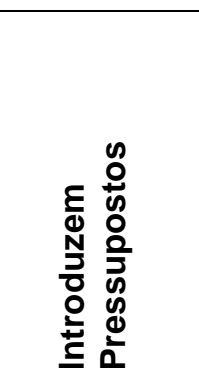 & 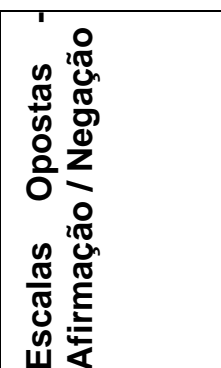 & 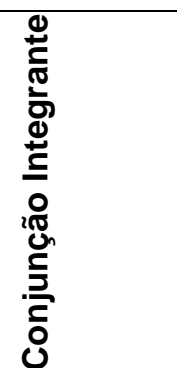 \\
\hline 89 & $\begin{array}{l}\text { I.15 - que } \\
\text { I.16 - porque } \\
\text { I.21 - que } \\
\text { I.26 - visto que } \\
\text { I.30 - pois } \\
\text { I.32 - que } \\
\text { I.37 - pois } \\
\text { I.39 - já que } \\
\text { I.42 - porque } \\
\text { I.48 - que }\end{array}$ & $\begin{array}{c}\text { I.13 - mas } \\
\text { I.41 - apesar } \\
\text { de }\end{array}$ & $\begin{array}{l}\text { l.8 - já } \\
\text { l.17 - ainda } \\
\text { l.46 - ainda }\end{array}$ & I.24 - pouco & $\begin{array}{l}\text { I.6 - que } \\
\text { I.10 - que } \\
\text { I.13 - que } \\
\text { I.15 - que } \\
\text { I.17 - que } \\
\text { I.17 - que } \\
\text { I.18 - que } \\
\text { I.21 - que } \\
\text { I.22 - que } \\
\text { I.23 - que } \\
\text { I.25 - que } \\
\text { I.35 - que } \\
\text { I.38 - que } \\
\text { I.41 - que } \\
\text { I.45 - que } \\
\text { I.49- que }\end{array}$ \\
\hline 128 & $\begin{array}{l}\mathrm{I} .7 \text { - que } \\
\mathrm{l} .13 \text { - pois } \\
\mathrm{l} .14 \text { - que } \\
\mathrm{l} .20 \text { - porque } \\
\mathrm{I} .27 \text { - que }\end{array}$ & $\begin{array}{l}\text { I.2 - mas } \\
\text { I.25- mas }\end{array}$ & & & $\begin{array}{l}\text { I.16-que } \\
\text { l.17-que } \\
\text { l.28-que }\end{array}$ \\
\hline 130 & $\begin{array}{l}.1 \text { - que } \\
\text { I.6 - porque } \\
\text { I.8 - pois } \\
\text { l.9 - já que } \\
\text { l.10 - que } \\
\text { I.12 - que } \\
\text { I.21 - que } \\
\text { l.23 - pois } \\
\text { I.26 - que } \\
\text { l.27 - já que }\end{array}$ & I.36 - embora & I.25 - já & $\begin{array}{l}.4 \text { - quase } \\
\text { I.13 - apenas }\end{array}$ & $\begin{array}{l}l .5 \text { - que } \\
\text { l.18 - que } \\
l .22 \text { - que } \\
\text { l.23 - que } \\
l .26 \text { - se } \\
\text { l.37 - que } \\
\text { l.39 - que }\end{array}$ \\
\hline 201 & $\begin{array}{l}\mathrm{l} .7 \text { - que } \\
\mathrm{l} .17 \text { - que } \\
\mathrm{l} .18 \text { - que } \\
\mathrm{l} .19 \text { - porque } \\
\mathrm{l} .20 \text { - que } \\
\mathrm{l} .23 \text { - que } \\
\mathrm{l} .26 \text { - porque } \\
\mathrm{l} .33 \text { - porque }\end{array}$ & & & & $\begin{array}{l}\text { I.21 - que } \\
\text { I.24 - que }\end{array}$ \\
\hline
\end{tabular}




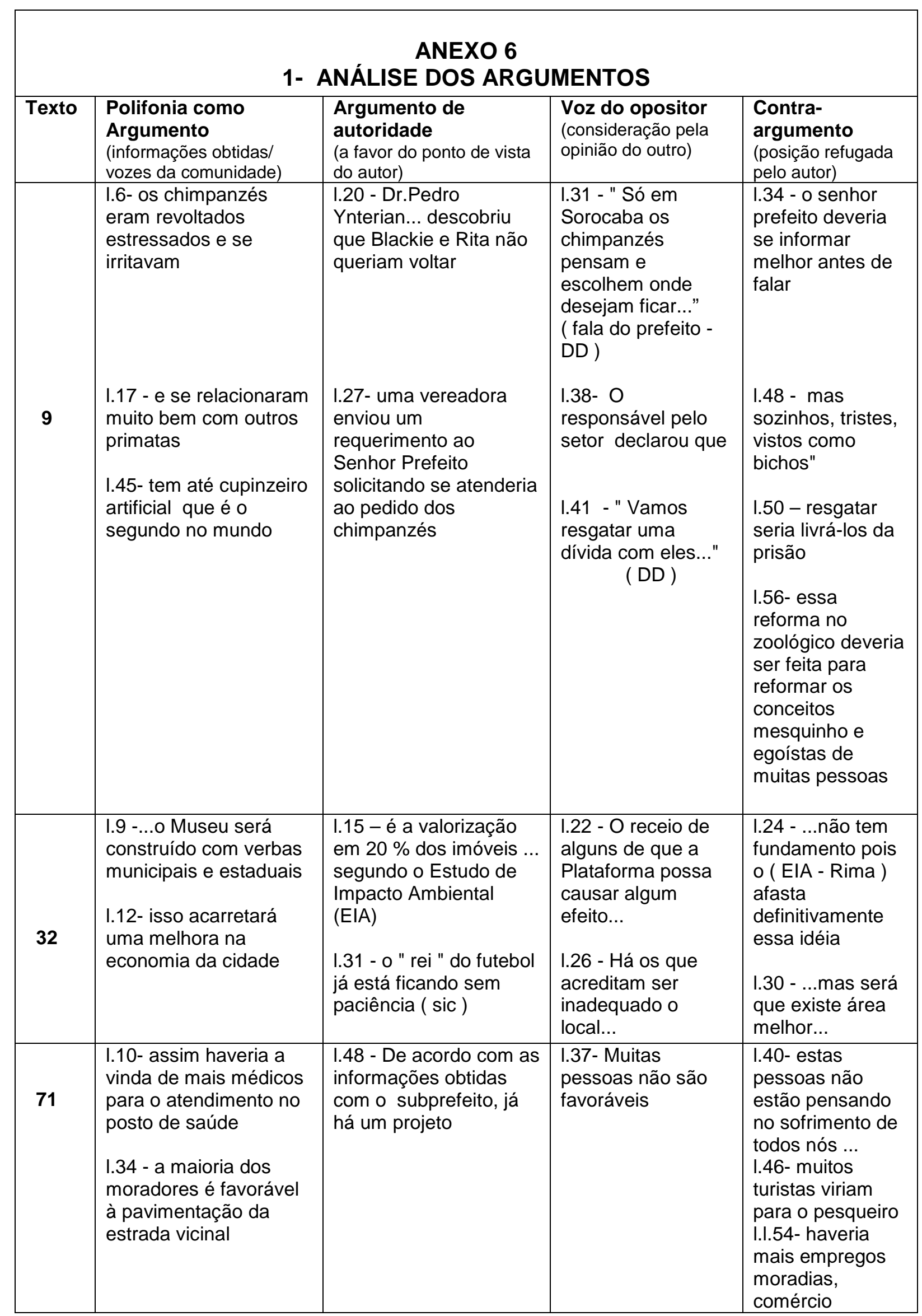




\section{1- ANÁLISE DOS ARGUMENTOS}

\begin{tabular}{|c|c|c|c|c|}
\hline Texto & $\begin{array}{l}\text { Polifonia como } \\
\text { Argumento } \\
\text { (informações obtidas/ } \\
\text { vozes da comunidade) }\end{array}$ & $\begin{array}{l}\text { Argumento de } \\
\text { autoridade } \\
\text { (a favor do ponto de vista } \\
\text { do autor) }\end{array}$ & $\begin{array}{l}\text { Voz do opositor } \\
\text { (consideração pela } \\
\text { opinião do outro) }\end{array}$ & $\begin{array}{l}\text { Contra- } \\
\text { argumento } \\
\text { (posição refugada } \\
\text { pelo autor) }\end{array}$ \\
\hline 76 & $\begin{array}{l}\text { I.9 - ...o número de } \\
\text { pessoas à favor é } \\
\text { muito maior } \\
\text { I.14 - a Prefeitura de } \\
\text { Guarulhos não da a } \\
\text { atenção necessária... } \\
\text { uma vez que se recusa } \\
\text { visitar o local }\end{array}$ & & $\begin{array}{l}\text { I.19 - A Secretaria } \\
\text { de Transportes do } \\
\text { município alega } \\
\text { que vai contra as } \\
\text { regras de trânsito }\end{array}$ & $\begin{array}{l}\text { I.23 - A meu ver, } \\
\text { os dirigentes } \\
\text { estão } \\
\text { empurrando o } \\
\text { problema uns } \\
\text { para os outros }\end{array}$ \\
\hline 89 & $\begin{array}{l}\text { I.5 - Um cafeicultor } \\
\text { pediu um espaço ao } \\
\text { prefeito } \\
\text { I.12 - Algumas pessoas } \\
\text { estão revoltadas com a } \\
\text { atitude do prefeito } \\
\text { I.15 - Os que são } \\
\text { contra dizem } \\
\text { I.48 - concordo com } \\
\text { aqueles que dizem que }\end{array}$ & $\begin{array}{l}\text { I.39 - como foi } \\
\text { publicado no jornal da } \\
\text { cidade o cafeicultor é o } \\
\text { maior produtor da } \\
\text { região } \\
\text { I.44 - o promotor de } \\
\text { justiça de Dois } \\
\text { Córregos afirmou que a } \\
\text { "medida é } \\
\text { juridicamente } \\
\text { discutível" }\end{array}$ & $\begin{array}{l}\text { I.9 - Segundo ele, } \\
\text { se o prefeito não } \\
\text { cedesse um } \\
\text { espaço ele teria de } \\
\text { parar com a safra } \\
\text { I.12 - mas outras } \\
\text { consideram que ele } \\
\text { está certo } \\
\text { I.21- Os que são } \\
\text { favoráveis dizem ... } \\
\text { que a avenida é } \\
\text { larga o suficiente } \\
\text { para ser usada em } \\
\text { mão dupla } \\
\text { I.41- Apesar de } \\
\text { algumas pessoas } \\
\text { garantirem que o } \\
\text { decreto do prefeito } \\
\text { é legal }\end{array}$ & $\begin{array}{l}\text { I.35- deveria ter } \\
\text { construído outros } \\
\text { terreiros ... ou } \\
\text { encontrar outra } \\
\text { solução } \\
\text { I.38 - acredito } \\
\text { que dinheiro não } \\
\text { é problema para } \\
\text { ele } \\
\text { I.25- com a pista } \\
\text { interditada havia } \\
\text { a possibilidade } \\
\text { de acontecer } \\
\text { acidentes } \\
\text { I.44- "a medida é } \\
\text { juridicamente } \\
\text { discutível" } \\
\text { I.49- a campanha } \\
\text { e o dinheiro } \\
\text { falaram mais alto }\end{array}$ \\
\hline 128 & $\begin{array}{l}\text { I.1 - Itaí é considerada } \\
\text { uma cidade pequena } \\
\text { I. 24- os acidentes com } \\
\text { automóveis diminuíram } \\
\text { muito na cidade }\end{array}$ & & $\begin{array}{l}\text { I.16- Muitas } \\
\text { pessoas afirmam } \\
\text { que por ser uma } \\
\text { cidade pequena, } \\
\text { não é necessário } \\
\text { semáforo } \\
\\
\text { I.18 dizendo que } \\
\text { perdem muito } \\
\text { tempo esperando } \\
\text { abrir o sinal verde }\end{array}$ & $\begin{array}{l}\text { I.19 - Isso não é } \\
\text { motivo para não } \\
\text { usar semáforo } \\
\text { I.21- os } \\
\text { semáforos ... } \\
\text { dando mais } \\
\text { organização } \\
\text { I.28- se houvesse } \\
\text { semáforo, isso } \\
\text { não teria } \\
\text { acontecido } \\
\text { I.31- ótimo } \\
\text { investimento, } \\
\text { oferecendo mais } \\
\text { segurança aos } \\
\text { cidadãos } \\
\text { itaienses }\end{array}$ \\
\hline
\end{tabular}




\section{1 - ANÁLISE DOS ARGUMENTOS}

\begin{tabular}{|c|c|c|c|c|}
\hline Texto & $\begin{array}{l}\text { Polifonia como } \\
\text { Argumento } \\
\text { (informações obtidas/ } \\
\text { vozes da comunidade) }\end{array}$ & $\begin{array}{l}\text { Argumento de } \\
\text { autoridade } \\
\text { (a favor do ponto de vista } \\
\text { do autor) }\end{array}$ & $\begin{array}{l}\text { Voz do opositor } \\
\text { (consideração pela } \\
\text { opinião do outro) }\end{array}$ & $\begin{array}{l}\text { Contra-argumento } \\
\text { (posição refugada } \\
\text { pelo autor) }\end{array}$ \\
\hline 130 & $\begin{array}{l}\text { I.21 - dizem que será } \\
\text { escorregadio } \\
\text { I.34 - O término do } \\
\text { trabalho esta com } \\
\text { previsão para o dia } \\
\text { dois de setembro }\end{array}$ & $\begin{array}{l}\text { I.9 - segundo } \\
\text { especialistas, essa } \\
\text { restauração está } \\
\text { saindo muito cara } \\
\text { I.31- conforme o relato } \\
\text { do dono da Padaria } \\
\text { Central, Rodrigo } \\
\text { Carvalho Braga } \\
\text { I.36- o arquiteto } \\
\text { responsável, Adelino } \\
\text { Fontana Jr, já tenha } \\
\text { dito que "existia uma } \\
\text { grande confusão de } \\
\text { conceitos" }\end{array}$ & $\begin{array}{l}\text { I.5- muitos dizem } \\
\text { que ela estava } \\
\text { precisando de uma } \\
\text { reforma } \\
\text { I.18- Muitas } \\
\text { pessoas dizem que } \\
\text { com essa } \\
\text { modificação haverá } \\
\text { uma praça de } \\
\text { alimentação ... com } \\
\text { a troca de todo o } \\
\text { piso } \\
\text { I.36 -o arquiteto ... } \\
\text { afirmando a } \\
\text { necessidade dessa } \\
\text { obra }\end{array}$ & $\begin{array}{l}\text { I.10 - Ao invés de } \\
\text { fazer calçadas, } \\
\text { tapar buracos ... } \\
\text { eles constroem } \\
\text { coisas que não } \\
\text { serão úteis para a } \\
\text { população } \\
\text { I.16 - poderiam } \\
\text { fazer até algumas } \\
\text { mudanças desde } \\
\text { que fosse por um } \\
\text { preço menor } \\
\text { I.22- perigoso até } \\
\text { as pessoas se } \\
\text { machucarem } \\
\text { I.38 -eles tinham } \\
\text { que pensar muito } \\
\text { antes de iniciá-la. } \\
\text { I. } 40 \text { Temos outras } \\
\text { necessidades ... } \\
\text { muito mais } \\
\text { urgentes } \\
\text { I.41- " com dinheiro } \\
\text { não se brinca " }\end{array}$ \\
\hline 201 & $\begin{array}{l}\text { I.13 - Eles estão } \\
\text { investindo uma } \\
\text { quantidade maior de } \\
\text { dinheiro em } \\
\text { transportes nas } \\
\text { grandes avenidas }\end{array}$ & & $\begin{array}{l}\text { I.23 - Há pessoas } \\
\text { que não } \\
\text { concordam...elas } \\
\text { dizem que não há } \\
\text { espaço o bastante } \\
\text { para a construção } \\
\text { dessas praças }\end{array}$ & $\begin{array}{l}\text { I.19- os jovens } \\
\text { trocariam as ruas } \\
\ldots \text { por um lugar } \\
\text { mais seguro } \\
\text { I.21- diminuiria... a } \\
\text { violência } \\
\text { I.26- elas podem } \\
\text { pagar o alto custo } \\
\text { de uma passagem } \\
\text { para ir ao cinema } \\
\text { I.29- eu não } \\
\text { concordo pensar } \\
\text { dessa forma } \\
\text { egoísta } \\
\text { I.30- todos } \\
\text { deveriam colaborar } \\
\text { para ter uma } \\
\text { comunidade melhor } \\
\text { I.33 - nosso bairro } \\
\text { será mais } \\
\text { valorizado }\end{array}$ \\
\hline
\end{tabular}




\begin{tabular}{|c|c|c|c|c|}
\hline \multicolumn{5}{|c|}{2 - ANÁLISE DOS ARGUMENTOS } \\
\hline Texto & Lugar do preferível & $\begin{array}{l}\text { Repetição de palavras } \\
\text { (Intenção argumentativa) }\end{array}$ & $\begin{array}{l}\text { Ad personam } \\
\text { (desqualificar o } \\
\text { adversário) }\end{array}$ & $\begin{array}{l}\text { Lugar de } \\
\text { quantidade }\end{array}$ \\
\hline 9 & $\begin{array}{l}\text { I.50- para que tivessem } \\
\text { uma vida digna }\end{array}$ & $\begin{array}{l}\text { I.41- resgatar } \\
\text { I.50- resgatar } \\
\text { I.42- digna } \\
\text { I.51- digna } \\
\text { I.56- reforma } \\
\text { I.57- reformar }\end{array}$ & $\begin{array}{l}\text { I.34- O Senhor } \\
\text { Prefeito deveria } \\
\text { se informar } \\
\text { melhor antes de } \\
\text { falar } \\
\text { I.56- essa reforma } \\
\text { deveria servir } \\
\text { para reformar os } \\
\text { conceitos } \\
\text { mesquinhos e } \\
\text { egoístas de } \\
\text { muitas pessoas } \\
\text { de muitas } \\
\text { pessoas }\end{array}$ & \\
\hline 32 & $\begin{array}{l}\text { I.8- vai gerar empregos } \\
\text { I.12- isso acarretará } \\
\text { melhora na economia } \\
\text { I.20- valorização ...dos } \\
\text { imóveis }\end{array}$ & $\begin{array}{l}\text { I.38- acervo/ acervo } \\
\text { I.15- valorização } \\
\text { I.40- valorizar }\end{array}$ & $\begin{array}{l}\text { I.40-É preciso } \\
\text { valorizar o que é } \\
\text { da terra }\end{array}$ & $\begin{array}{l}2^{\circ} \S \text { - mais } \\
\text { empregos } \\
3^{\circ} \S \text { mais } \\
\text { valorização da } \\
\text { região, mais } \\
\text { turismo }\end{array}$ \\
\hline 71 & & $\begin{array}{l}\text { I.15- muitos } \\
\text { I.17- muita } \\
\text { I.19 muitas } \\
\text { I.25- muito } \\
\text { I.37- muitas } \\
\text { I.38- muito } \\
\text { I.45- muito } \\
\text { I.46- muitos } \\
\text { I.9- melhoraria } \\
\text { I.35- melhorias } \\
\text { I.44- melhoraria } \\
\text { I.55- melhoria } \\
\text { I.9- mais } \\
\text { I.11- mais } \\
\text { I.20- mais }\end{array}$ & $\begin{array}{l}.40-\text { estas } \\
\text { pessoas não } \\
\text { estão pensando } \\
\text { no sofrimento de } \\
\text { todos nós que } \\
\text { moramos em } \\
\text { Amadeu Amaral e } \\
\text { no futuro dos } \\
\text { filhos dos } \\
\text { trabalhadores }\end{array}$ & $\begin{array}{l}\text { I.9- poderiam ter } \\
\text { mais linhas de } \\
\text { ônibus } \\
\text { I.14- os } \\
\text { problemas } \\
\text { gerados pela falta } \\
\text { de asfalto são } \\
\text { muitos... } \\
\text { diminuindo cada } \\
\text { vez mais } \\
\text { I.45- muitos } \\
\text { turistas viriam } \\
\text { para o pesqueiro } \\
\text { I.47- o número de } \\
\text { habitantes } \\
\text { cresceria } \\
\text { I.54- haveria mais } \\
\text { empregos, } \\
\text { moradias }\end{array}$ \\
\hline
\end{tabular}




\begin{tabular}{|c|c|c|c|c|}
\hline \multicolumn{5}{|c|}{2 - ANÁLISE DOS ARGUMENTOS } \\
\hline Texto & Lugar do preferível & $\begin{array}{l}\text { Repetição de palavras } \\
\text { (Intenção argumentativa) }\end{array}$ & $\begin{array}{l}\text { Ad personam } \\
\text { (desqualificar o } \\
\text { adversário) }\end{array}$ & $\begin{array}{l}\text { Lugar de } \\
\text { quantidade }\end{array}$ \\
\hline 76 & & $\begin{array}{l}\text { I.5- maior } \\
\text { I.8- maioria } \\
\text { I.10- maior }\end{array}$ & $\begin{array}{l}\text { I.12- a Prefeitura } \\
\text { de Guarulhos não } \\
\text { dá a atenção } \\
\text { necessária uma } \\
\text { vez que se recusa } \\
\text { visitar o local(sic) } \\
\text { I.23- os dirigentes } \\
\text { estão empurrando } \\
\text { o problema uns } \\
\text { para os outros }\end{array}$ & $\begin{array}{l}\text { I.10- o número de } \\
\text { pessoas à favor é } \\
\text { muito maior do } \\
\text { que as contra(sic) } \\
\text { I.24- Sou a favor } \\
\text { do semáforo, do } \\
\text { guarda na porta } \\
\text { da escola como } \\
\text { também de } \\
\text { placas de } \\
\text { sinalização }\end{array}$ \\
\hline 89 & & $\begin{array}{l}\text { I.33- deveria } \\
\text { I.35- deveria }\end{array}$ & $\begin{array}{l}\text { I.15- dizem que o } \\
\text { prefeito agiu com } \\
\text { intensões } \\
\text { políticas, porque } \\
\text { é candidato à } \\
\text { reeleição(sic) } \\
\text { I.36 ou tentar } \\
\text { encontrar outra } \\
\text { solução sem } \\
\text { incomodar os } \\
\text { cidadãos, pois } \\
\text { acredito que } \\
\text { dinheiro não é o } \\
\text { problema para ele } \\
\text { I.45- "a medida é } \\
\text { juridicamente } \\
\text { discutível" } \\
\text { I.46- pelo jeito } \\
\text { minha cidade } \\
\text { ainda vive no } \\
\text { tempo dos } \\
\text { coronéis } \\
\text { I.49- campanha } \\
\text { eleitoral e } \\
\text { dinheiro falaram } \\
\text { mais alto nesse } \\
\text { caso }\end{array}$ & \\
\hline
\end{tabular}




\begin{tabular}{|c|c|c|c|c|}
\hline \multicolumn{5}{|c|}{2 - ANÁLISE DOS ARGUMENTOS } \\
\hline Texto & Lugar do preferível & $\begin{array}{l}\text { Repetição de palavras } \\
\text { (Intenção argumentativa) }\end{array}$ & $\begin{array}{l}\text { Ad personam } \\
\text { (desqualificar o } \\
\text { adversário) }\end{array}$ & $\begin{array}{l}\text { Lugar de } \\
\text { quantidade }\end{array}$ \\
\hline 128 & $\begin{array}{l}\text { I.32- oferecendo mais } \\
\text { segurança aos } \\
\text { cidadãos itaienses }\end{array}$ & $\begin{array}{l}\text { I.21- muito } \\
\text { I.22- mais } \\
\text { I.25- muito } \\
\text { I.32- mais }\end{array}$ & $\begin{array}{l}\text { I.7- o prefeito } \\
\text { sucessor, que era } \\
\text { contra o sinaleiro, } \\
\text { mandou retirá-lo } \\
\text { da cidade } \\
\text { I.16- Isso não é } \\
\text { motivo para não } \\
\text { usar o semáforo }\end{array}$ & $\begin{array}{l}\text { I.10- instalou mais } \\
\text { três no centro } \\
\text { I.24- os acidente } \\
\text {... diminuíram } \\
\text { muito na cidade }\end{array}$ \\
\hline 130 & $\begin{array}{l}\text { I.10- Ao invés de fazer } \\
\text { calçadas, tapar } \\
\text { buracos da ruas, } \\
\text { investir na saúde e na } \\
\text { educação } \\
\text { I.40- Temos outras } \\
\text { necessidades em } \\
\text { Sertãozinho muito mais } \\
\text { urgentes }\end{array}$ & $\begin{array}{l}\text { Título: Com dinheiro } \\
\text { não se brinca } \\
\text { I.9- muito } \\
\text { I.29- muito } \\
\text { I.39- muito } \\
\text { I.41- "Com dinheiro não } \\
\text { se brinca!" (sic) }\end{array}$ & $\begin{array}{l}\text { I.11- eles } \\
\text { constroem coisas } \\
\text { que não serão } \\
\text { úteis } \\
\text { I.37- "existia uma } \\
\text { grande confusão } \\
\text { de conceitos" } \\
\text { I.38- eles tinham } \\
\text { que pensar muito } \\
\text { antes de iniciá-la }\end{array}$ & $\begin{array}{l}\text { I.17- desde que } \\
\text { fossem por um } \\
\text { preço menor } \\
\text { I.23- o número de } \\
\text { desempregados } \\
\text { aumentará }\end{array}$ \\
\hline 201 & $\begin{array}{l}\text { I.17- Precisamos de } \\
\text { um lugar que seja } \\
\text { grande, bonito e que } \\
\text { tenha ... segurança } \\
\text { I.33- ganhará mais vida }\end{array}$ & $\begin{array}{l}\text { I.5- muitos } \\
\text { I.12- mais } \\
\text { I.13- mais } \\
\text { I.17- muito } \\
\text { I.21- mais }\end{array}$ & $\begin{array}{l}\text { I.12- Os políticos } \\
\text { deveriam investir } \\
\text { mais nos bairros } \\
\text { periféricos } \\
\text { I.29- Eu não } \\
\text { concordo pensar } \\
\text { desta forma } \\
\text { egoísta (sic) }\end{array}$ & $\begin{array}{l}\text { I.5- existem } \\
\text { muitos moradores } \\
\text { de classes } \\
\text { variáveis } \\
\text { I.12- deviam } \\
\text { investir mais nos } \\
\text { bairros periféricos } \\
\text { I.14- estão } \\
\text { investindo uma } \\
\text { quantidade maior } \\
\text { de dinheiro } \\
\text { I.18- e que tenha } \\
\text { muito conforto } \\
\text { I.21- diminuiria a } \\
\text { questão da } \\
\text { violência } \\
\text { I.30- Todos } \\
\text { deveriam } \\
\text { colaborar } \\
\text { I.33- nosso bairro } \\
\text { será mais } \\
\text { valorizado }\end{array}$ \\
\hline
\end{tabular}




\begin{tabular}{|c|c|c|c|c|}
\hline \multicolumn{5}{|c|}{3 - ANÁLISE DOS ARGUMENTOS } \\
\hline Texto & Senso comum & $\begin{array}{l}\text { Argumento } \\
\text { pragmático }\end{array}$ & $\begin{array}{l}\text { Clichê/ } \\
\text { Máxima/'Provérbio }\end{array}$ & $\begin{array}{l}\text { Apresentação } \\
\text { de dados }\end{array}$ \\
\hline 9 & $\begin{array}{l}\text { I.51- para que } \\
\text { tivessem uma vida } \\
\text { digna com respeito }\end{array}$ & $\begin{array}{l}\text { I.16- Eles ficaram lá por } \\
\text { três meses e se } \\
\text { relacionaram muito } \\
\text { bem } \\
\text { I.48- estão bem, mas } \\
\text { sozinhos, tristes }\end{array}$ & & $\begin{array}{l}\text { I.16- ficaram lá } \\
\text { por três meses }\end{array}$ \\
\hline 32 & $\begin{array}{l}\text { I.5- Devido a } \\
\text { problemas } \\
\text { burocráticos o } \\
\text { empreendimento não } \\
\text { sai do papel. }\end{array}$ & $\begin{array}{l}\text { I.12- Isso acarretará } \\
\text { uma melhora na } \\
\text { economia da cidade. } \\
\text { I.19- Com a construção } \\
\text { do museu Pelé, } \\
\text { acredita-se que esses } \\
\text { valores mudarão }\end{array}$ & $\begin{array}{l}\text { I.40- É preciso } \\
\text { valorizar o que é da } \\
\text { terra }\end{array}$ & $\begin{array}{l}\text { I.10- auditório } \\
\text { com capacidade } \\
\text { para } 186 \text { lugares } \\
\text { I.15- } 20 \% \text { dos } \\
\text { imóveis } \\
\text { I.18- } 43 \% \text { da } \\
\text { capital, } 42 \% \text { do } \\
\text { interior, } 12 \% \text { de } \\
\text { outros estados e } \\
\text { apenas } 2 \% \text { do } \\
\text { interior }\end{array}$ \\
\hline 71 & $\begin{array}{l}\text { I.16- após o período de } \\
\text { chuvas há muita lama }\end{array}$ & $\begin{array}{l}\text { I.9- haveria a vinda de } \\
\text { mais médicos } \\
\text { I.20- diminuiria a } \\
\text { população do local e a } \\
\text { movimentação do lugar } \\
\text { I.47- o número de } \\
\text { cresceria a economia } \\
\text { local também }\end{array}$ & $\begin{array}{l}\text { I.56- Eu estou } \\
\text { pensando no meu } \\
\text { futuro por isso } \\
\text { lutarei }\end{array}$ & \\
\hline 76 & $\begin{array}{l}\text { I.7- Vivendo em um } \\
\text { país democrático onde } \\
\text { a maioria vence } \\
\text { I.23- os dirigentes } \\
\text { estão empurrando o } \\
\text { problema uns para os } \\
\text { outros } \\
\text { I.28- sou favorável à } \\
\text { prevenção de } \\
\text { acidentes para todos }\end{array}$ & & & \\
\hline 89 & & & $\begin{array}{l}\text { I.46- minha cidade } \\
\text { ainda vive no } \\
\text { tempo dos coronéis } \\
\text { I.49- campanha } \\
\text { eleitoral e dinheiro } \\
\text { falaram mais alto }\end{array}$ & $\begin{array}{l}\text { I.42- está previsto } \\
\text { na lei orgânica do } \\
\text { município em seu } \\
\text { artigo } 94\end{array}$ \\
\hline
\end{tabular}




\begin{tabular}{|c|c|c|c|c|}
\hline \multicolumn{5}{|c|}{3 - ANÁLISE DOS ARGUMENTOS } \\
\hline Texto & Senso comum & $\begin{array}{l}\text { Argumento } \\
\text { pragmático }\end{array}$ & $\begin{array}{l}\text { Clichê/ } \\
\text { Máxima/ Provérbio }\end{array}$ & $\begin{array}{l}\text { Apresentação de } \\
\text { dados }\end{array}$ \\
\hline 128 & $\begin{array}{l}\text { I.16- evitam graves } \\
\text { acidentes com } \\
\text { veículos que podem } \\
\text { tirar vida de algumas } \\
\text { pessoas inocentes } \\
\text { I.31- oferecendo mais } \\
\text { segurança aos } \\
\text { cidadãos }\end{array}$ & $\begin{array}{l}\text { I.22- os semáforos ... } \\
\text { dando mais } \\
\text { organização no trânsito }\end{array}$ & & \\
\hline 130 & $\begin{array}{l}\text { I.22- É perigoso até as } \\
\text { pessoas se } \\
\text { machucarem. } \\
\text { I.11- investir na saúde, } \\
\text { na educação }\end{array}$ & $\begin{array}{l}\text { I.23- Penso que o } \\
\text { número de } \\
\text { desempregados } \\
\text { aumentará }\end{array}$ & $\begin{array}{l}\text { Título- Com } \\
\text { dinheiro não se } \\
\text { brinca } \\
\text { I.41- "Com dinheiro } \\
\text { não se brinca!" }\end{array}$ & $\begin{array}{l}\text { I.9- valor previsto } \\
\text { de } \\
R \$ 1.195 .279,31\end{array}$ \\
\hline 201 & $\begin{array}{l}\text { I.12- Os políticos } \\
\text { deveriam investir mais } \\
\text { nos bairros periféricos } \\
\text { e de classe mais baixa } \\
\text { I.30- Todos deveriam } \\
\text { colaborar para ter uma } \\
\text { comunidade melhor }\end{array}$ & $\begin{array}{l}\text { I.21- diminuiria a } \\
\text { questão da violência } \\
\text { nas ruas } \\
\text { I.33- nosso bairro será } \\
\text { mais valorizado e } \\
\text { ganhará mais vida }\end{array}$ & & \\
\hline
\end{tabular}




\begin{tabular}{|c|c|c|c|c|}
\hline \multicolumn{5}{|c|}{4 - ANÁLISE DOS ARGUMENTOS } \\
\hline Texto & $\begin{array}{c}\text { Presença } \\
\text { (relato/ descrição } \\
\text { deixam mais viva a } \\
\text { imagem) }\end{array}$ & Argumento de Justiça & Parte pelo todo & $\begin{array}{l}\text { Figura de } \\
\text { Comunhão }\end{array}$ \\
\hline 9 & Do $1^{\circ} \S$ ao $7^{\circ} \S$ & $\begin{array}{c}\text { Temos um sentimento } \\
\text { de justiça }\end{array}$ & & \\
\hline 32 & $\begin{array}{l}\text { I.10- terá três andares... } \\
\text { lojas, restaurante ... }\end{array}$ & & $\begin{array}{l}\text { l.38- acervo que } \\
\text { faz parte da } \\
\text { história de Santos } \\
\text { l.41- Pelé faz } \\
\text { parte dessa terra }\end{array}$ & I.31- rei do futebol \\
\hline 71 & Do $2^{\circ} \S$ ao $4^{\circ} \S$ & & & \\
\hline \multicolumn{5}{|c|}{$3 \S$ e $4^{\circ} \S$} \\
\hline 89 & $\begin{array}{l}1^{\circ} \S \S \text { e } 2^{\circ} \S \\
7^{a} \S\end{array}$ & $\begin{array}{l}\text { I.19- essa atitude abre } \\
\text { precedentes para outros } \\
\text { produtores solicitarem o } \\
\text { mesmo benefício }\end{array}$ & & \\
\hline 128 & $\begin{array}{l}2^{\circ} \S \\
60 \S\end{array}$ & & & \\
\hline 130 & $\begin{array}{l}\text { I.4 era feia e suja } \\
\text { devido aos dejetos dos } \\
\text { pássaros. } \\
66^{\circ} \S \\
8^{\circ} \S \\
9 \cong \S\end{array}$ & & & \\
\hline 201 & $2^{\circ} \S$ & & & \\
\hline
\end{tabular}




\begin{tabular}{|c|c|c|c|c|}
\hline \multicolumn{6}{|c|}{ 5 - ANÁLISE DOS ARGUMENTOS } \\
\hline Texto & Ilustração & \multicolumn{1}{|c|}{ Gradação } & Comparação & $\begin{array}{c}\text { Interação dos } \\
\text { argumentos }\end{array}$ \\
\hline $\mathbf{9}$ & & & $\begin{array}{l}\text { I.49- como bichos } \\
\text { em extinção }\end{array}$ & $\mathbf{X}$ \\
\hline $\mathbf{3 2}$ & & $\begin{array}{l}\text { l.30- existe área } \\
\text { melhor do que } \\
\text { essa }\end{array}$ & $\mathbf{X}$ \\
\hline $\mathbf{7 1}$ & & & & $\mathbf{X}$ \\
\hline $\mathbf{7 6}$ & & $\begin{array}{l}\text { l.24- Sou a favor do } \\
\text { semáforo, do guarda na } \\
\text { porta da escola como } \\
\text { também de placas de } \\
\text { sinalização }\end{array}$ & $\mathbf{X}$ \\
\hline $\mathbf{8 9}$ & & & & $\mathbf{X}$ \\
\hline $\mathbf{1 2 8}$ & $\begin{array}{l}\text { I.26- um aluno .... que } \\
\text { morreu atropelado }\end{array}$ & & & $\mathbf{X}$ \\
\hline $\mathbf{1 3 0}$ & & & & $\mathbf{X}$ \\
\hline
\end{tabular}


ANEXO 7

CADERNO CÁ ENTRE NÓS 